\title{
Taekwondo and physical fitness components in middle-aged healthy volunteers : the Sekwondo study
}

Citation for published version (APA):

Pons van Dijk, G. (2015). Taekwondo and physical fitness components in middle-aged healthy volunteers : the Sekwondo study. [Doctoral Thesis, Maastricht University]. Maastricht University. https://doi.org/10.26481/dis.20151029gp

Document status and date:

Published: 01/01/2015

DOI:

10.26481/dis.20151029gp

Document Version:

Publisher's PDF, also known as Version of record

\section{Please check the document version of this publication:}

- A submitted manuscript is the version of the article upon submission and before peer-review. There can be important differences between the submitted version and the official published version of record.

People interested in the research are advised to contact the author for the final version of the publication, or visit the DOI to the publisher's website.

- The final author version and the galley proof are versions of the publication after peer review.

- The final published version features the final layout of the paper including the volume, issue and page numbers.

Link to publication

\footnotetext{
General rights rights.

- You may freely distribute the URL identifying the publication in the public portal. please follow below link for the End User Agreement:

www.umlib.nl/taverne-license

Take down policy

If you believe that this document breaches copyright please contact us at:

repository@maastrichtuniversity.nl

providing details and we will investigate your claim.
}

Copyright and moral rights for the publications made accessible in the public portal are retained by the authors and/or other copyright owners and it is a condition of accessing publications that users recognise and abide by the legal requirements associated with these

- Users may download and print one copy of any publication from the public portal for the purpose of private study or research.

- You may not further distribute the material or use it for any profit-making activity or commercial gain

If the publication is distributed under the terms of Article $25 \mathrm{fa}$ of the Dutch Copyright Act, indicated by the "Taverne" license above, 
Taekwondo and physical fitness components in middle-aged healthy volunteers;

The Sekwondo study 
ISBN 978-94-6259-872-0

CC Gaby Pons van Dijk, Maastricht 2015

Production: Gaby 


\title{
Taekwondo and physical fitness components in middle-aged healthy volunteers; The Sekwondo study
}

\author{
PROEFSCHRIFT \\ Ter verkrijging van de graad van doctor aan de \\ Universiteit Maastricht \\ op gezag van de Rector Magnificus, Prof. Dr. L.L.G. Soete, \\ volgens het besluit van het College van Decanen, \\ in het openbaar te verdedigen op \\ donderdag 29 oktober 2015 om 16.00 uur
}

Door

Gabriëlla Pons van Dijk 


\section{Promotores}

Prof. Dr. J. Lodder

Prof. Dr. H. Kingma

\section{Copromotor}

Dr. A.F. Lenssen

\section{Beoordelingscommissie}

Prof. Dr. R. van Oostenbrugge (voorzitter)

Prof. Dr. R. Ponds

Prof. Dr. T.hortobagyi, Universitair Medisch Centrum Groningen

Prof. Dr. J. Verbunt 


\section{Table of Contents}

1. The Effectiveness of Hard Martial Arts in People over Forty: An Attempted Systematic Review

$\begin{array}{lr}\text { Abstract } & 10 \\ \text { Introduction } & 11 \\ \text { Methods } & 12 \\ \text { Results } & 13 \\ \text { Discussion and conclusions } & 18 \\ \text { Appendix } & 24 \\ \text { References } & 26\end{array}$

2. Feasibility, safety and subjective experience of a one-year WTF-Taekwondo training course for middle-aged volunteers; the Sekwondo study

$\begin{array}{ll}\text { Abstract } & 30\end{array}$

$\begin{array}{ll}\text { Introduction } & 31\end{array}$

Participants and methods $\quad 31$

Results 33

Discussion $\quad 35$

$\begin{array}{ll}\text { References } & 39\end{array}$

3. Taekwondo training improves balance in volunteers over 40

$\begin{array}{lr}\text { Abstract } & 44 \\ \text { Introduction } & 45 \\ \text { Methods } & 45 \\ \text { Results } & 49 \\ \text { Discussion } & 51 \\ \text { References } & 54\end{array}$

4. Cognition improvement inTaekwondo novices over 40. Results from the SEKWONDO Study

Abstract

Introduction $\quad 59$

Methods $\quad 59$ 
5. Effects of Taekwondo training on muscle strength and physical fitness in middle-aged volunteers: The Sekwondo study.
Abstract 70
Introduction
Methods
Results 73
Discussion 76
References

6. Effects of one year Taekwondo training on flexibility in novices over 40. The Sekwondo study.
Abstract 84
Introduction 85
Methods 85
Results 87
Discussion 88
References 90

7. General discussion

General discussion 93

Conclusion 97

References 99

8. Summary 101

9. Samenvatting 107

10. Valorisatie 113

Curiculum Vitae 


\section{1}

\section{General introduction}

The Effectiveness of Hard Martial Arts in People over Forty: An Attempted Systematic Review

G. Pons van Dijk, P. Leffers and J. Lodder

Published: Societies 2014, 4(2), 161-179; doi:10.3390/soc4020161 


\section{Abstract}

The objective was to assess the effect of hard martial arts on the physical fitness components such as balance, flexibility, gait, strength, cardiorespiratory function and several mental functions in people over forty. A computerized literature search was carried out. Studies were selected when they had an experimental design, the age of the study population was $>40$, one of the interventions was a hard martial art, and when at least balance and cardiorespiratory functions were used as an outcome measure. We included four studies, with, in total, 112 participants, aged between 51 and 93 years. The intervention consisted of Taekwondo or Karate. Total training duration varied from 17 to $234 \mathrm{~h}$. All four studies reported beneficial effects, such as improvement in balance, in reaction tests, and in duration of single leg stance. We conclude that because of serious methodological shortcomings in all four studies, currently there is suggestive, but insufficient evidence, that hard martial arts practice improves physical fitness functions in healthy people over 40 . However, considering the importance of such effects, and the low costs of the intervention, the potential of beneficial health effects of age-adapted, hard martial arts training, in people over 40 , warrants further study. 


\section{Introduction}

The American College of Sport Medicine (ACSM) estimated that about $60 \%$ of Americans lack sufficient daily exercise, while about $25 \%$ has almost none ${ }^{1}$. In the Netherlands, about $25 \%$ of people lack sufficient daily physical activity, and about $10 \%$ do not exercise at all ${ }^{2,3}$. A low level of physical activity relates to an increased risk of cardiovascular disease, diabetes mellitus, osteoporosis, and has a negative effect on mood, cognitive functions and overall wellbeing. With increasing age these negative consequences lead to deterioration of mobility, jeopardizing self-maintenance and increase the chance of dependency on others ${ }^{4-6}$. Especially dynamic locomotor components deteriorate with age: steps become shorter, walking pace decreases, the time that both feet touch the ground increases during walking straight, but also in curves and while turning ${ }^{6,7}$. A decreased quality of the dynamic locomotor components also increases the risk of falling ${ }^{8}$.

Exercise programs, including those based on martial arts, lower the chance of a number of negative consequences of aging ${ }^{9}$. Physical activity and sports which are mainly focused on the training of the proprioceptive system (balance sports like Tai Chi and Yoga) are effective in improving balance and in reducing the prevalence of falls in the elderly ${ }^{7}$. Such sports are clearly better to improve balance function than sports that aim to improve cardiovascular function (bioenergetic sports, such as running) ${ }^{10}$.

Martial arts are often considered as either "soft", such as Tai Chi and Yoga, or "hard", such as Tae Kwon Do, Kung Fu, and Karate. Generally, hard martial arts focus on powerful execution of a limited number of movement techniques (those which most quickly and successfully take the opponent out), whereas soft martial arts primarily value the quality of execution of a much wider variety of movements; without losing sight of the fact that these movements relate to defense and attack patterns ${ }^{11}$. However, some martial arts, such as Tae Kwon Do, contain both elements. The element which makes hard martial techniques effective is the power to hit a target, which, apart from a certain degree of technique, requires both muscle strength and speed of execution. As most movements in the hard martial arts have a more dynamic nature than those in the soft martial arts, components of hard martial arts training may be expected to be especially beneficial on dynamic locomotor components ${ }^{12}$.

A number of studies and reviews examined the effects of soft martial arts, especially Tai Chi, on some physical fitness components such as balance, but also on the risk of fall accidents in the elderly ${ }^{6,13}$.

We hypothesize that hard martial art practice is more beneficial with regards to physical and mental functions because it combines the elements of soft martial arts with those of bioenergetics sports. Therefore, hard martial art practice could not only improve cardio-respiratory functions as in the bio-energetic sports, but also balance maintenance as in the soft martial arts. As the hard martial arts not only contain complex movement patterns as does, e.g., Tai Chi, they require a much more dynamic performance of these complexes, by which the physical fitness component "motor coordination" may especially benefit. A point of special interest, however, is balancing potential benefits against potential injuries, the occurrence of which may depend on the complexity and intensity of movement practice.

A review of 23 studies on effects on some physical functions of Taekwondo training suggested benefits on aerobic capacity, body composition and flexibility. However, that review was descriptive and considered no age specification ${ }^{13}$. In this paper we sought to study the evidence whether hard martial art practice improves certain physical fitness components in people over 40 . We set the age limit at 40 for several reasons: above this age the sport practice has lost the aim of competitive gain, whereas it is almost 
exclusively practiced for fun and physical and mental benefit, which were the parameters for our review. As training practice intensity in this age group is generally lower than in youngsters and young adults, not only a lower risk of training injuries may be expected, but any effect on our parameters of interest may substantially vary between these age groups. Furthermore, there is a psychological reason when 40 years of age may be regarded as being half-way one's expected total life span of 80 . If shown to be effective, such practice could then be recommended as an effective, safe and cost-effective method to improve certain health-related physical functions for people in this age category. With this aim we performed a systematic literature review of hard martial art intervention studies.

\section{Methods}

\section{Search Strategy}

We conducted a broad computerized literature search, over a period without a fixed date of onset up to May 2013, of Pubmed, Psychlit, Cochrane Database and Google search. Search terms were (a) hard martial arts; (b) participants older than 40 years; (c) measurements: balance, cardiorespiratory functions, mental functions (d) there was no time-limit and (e) written in English, Spanish, French, German or Dutch. This was specified with the following key words: martial arts, hard martial arts, Tae Kwon Do, Taekwondo, Karate, Hapkido, Kung Fu, older adults, aged, elderly and senior. We aimed primarily at (randomized) controlled trials, but also included other type prospective intervention studies.

The titles and abstracts of identified published articles were reviewed in order to determine their potential relevance tour aim. Also, reference lists of approved articles were screened for potentially relevant articles, which were reviewed in the same manner. In order to make a final selection of the studies for the review, one reviewer (GPD) applied all search criteria to the full text of the articles that had passed the first screening for eligibility.

\section{Risk of Bias Assessment}

A dedicated quality of methodology checklist was drawn up, based on of the published Delphi list, and with reference to the topic of the review ${ }^{14}$. The checklist was pretested using a non-randomized controlled study that studied the effects of Tai Chi on balance and selected motor functions of the elderly ${ }^{15}$. Only, minor changes had to be made for the final version (Appendix 1).

Two reviewers (GPD, PL) independently performed the methodological scoring of the selected studies. Their scores were compared and discrepancies were resolved through discussion between the reviewers. A third reviewer (JL) was to be consulted when differences could not easily be resolved.

\section{Data Extraction}

A study description form was developed based on standardized abstracting forms (Appendix 2). Data on all reported outcomes were extracted and assessed. 


\section{Analysis}

The methodological scoring list consisted of 18 items (see Appendix 1) with a positive, a partial and a negative answer option, they were scored as 2, 1 or 0 points respectively. If bias was considered unlikely, the item was scored positive. In case information was incomplete to allow good judgment, the item was scored as "partial", and without relevant information, "negative". The article was considered as poor with a score under 50\%, reasonable with a score $50 \%-75 \%$, and good above $75 \%$. Heterogeneity between studies did not allow statistical pooling of study results.

\section{Results}

\section{Search Strategy}

Our search resulted in 13 references of potential studies. Based on title and abstract, nine references were selected and the full text review excluded three more, as the intervention in fact complied rather with soft martial arts. One article was conducted by our own research group and was excluded because of possible bias in assessing quality ${ }^{16}$. One study did not meet selection criteria, because it was a retrospective trial ${ }^{17}$. Eventually, four papers were included in this review ${ }^{9,18-20}$. See Figure 1.

Figure 1. Results of search.

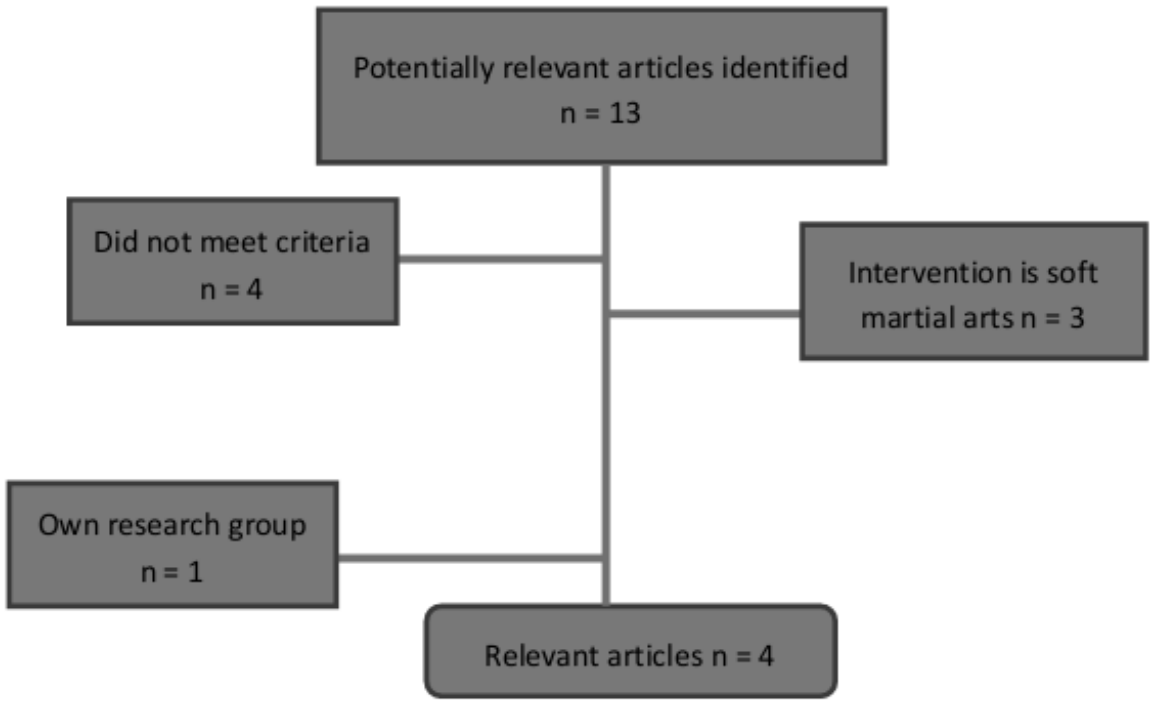

Risk of Bias Assessment

The four selected papers were two controlled trials, and two single arm intervention studies (Table 1). The little disagreement between reviewers occurred because of reading errors and differences in 
interpretation of the methodological criteria list. These differences could be easily resolved, and the third reviewer was not called upon. The results of the methodological assessment are presented in Table 2.

\section{Study Characteristics}

The study characteristics are presented in Table 1. Four studies with a total of 112 participants were included in this review, which came from two studies on Tae Kwon Do, and two studies on Karate.

Brudnak et al. tested one group of community-dwelling volunteers who followed Tae Kwon Do lessons for $1 \mathrm{~h}$ once a week, during 17 weeks. They functioned as their own reference group by measuring before and after the intervention period. The outcome variables were change of trunk flexibility, number of pushups and duration of single leg stance, and were measured before and following the training period [18].

Cromwell et al. divided the study population of community-dwelling volunteers, an index and a reference group, non-randomized. The division was based upon the choice of the volunteers. The index group followed a Taekwondo $1 \mathrm{~h}$ lessons twice a week, for 11 weeks. The Tae Kwon Do classes followed a standardized, clearly described curriculum. The non-exercising referents maintained their current lifestyle.

The outcome measures consisted of single leg stance, multidirectional reach test, timed up-and-go, walking velocity, cadence, gait stability ratio, sit-and-reach. They were measured before participation and after 11 weeks of Taekwondo lessons ${ }^{9}$.

Chateau-Degat et al. tested 15 healthy 50-year-old males, who attended adapted karate training, which was clearly described, for at least three weekly sessions of $90 \mathrm{~min}$ each for 12 months. They functioned as their own reference group and were measured at least one week before training, 6 months and 12 months after participation ${ }^{19}$. The outcome measures consisted of the MOS 36-item Short Form Health Survey ${ }^{21}$, the Beck Depression Inventory, reaction time, pronation and supination, finger tapping, sway path, area and sway velocity, and effort ${ }^{19}$.

Jansen et al. considered four groups of elderly people between 67 and 93 years of age: a physical exercise group ( $N=12)$, a cognitive training group $(N=12)$, one on Shokotan-Karate training $(N=12)$, and a reference group $(\mathrm{N}=9$ ). This division mainly came about by the volunteers' preference; inhabitants of different nursing homes wanted to stay together, as did (married) couples. In each of the 4 groups 20 training sessions were provided in a period of 3-6 months. The outcome measures were: cognitive speed, measured by the numberconnection test and the number-symbol test; memory performance, measured by the digit-span-test, the figure test and the block-tapping test; and the Centre of Epidemiological Studies Depressions scale, which measures different stages of depressive symptoms. They were measured prior to training, whereas posttesting was done immediately after the last training session ${ }^{20}$. 


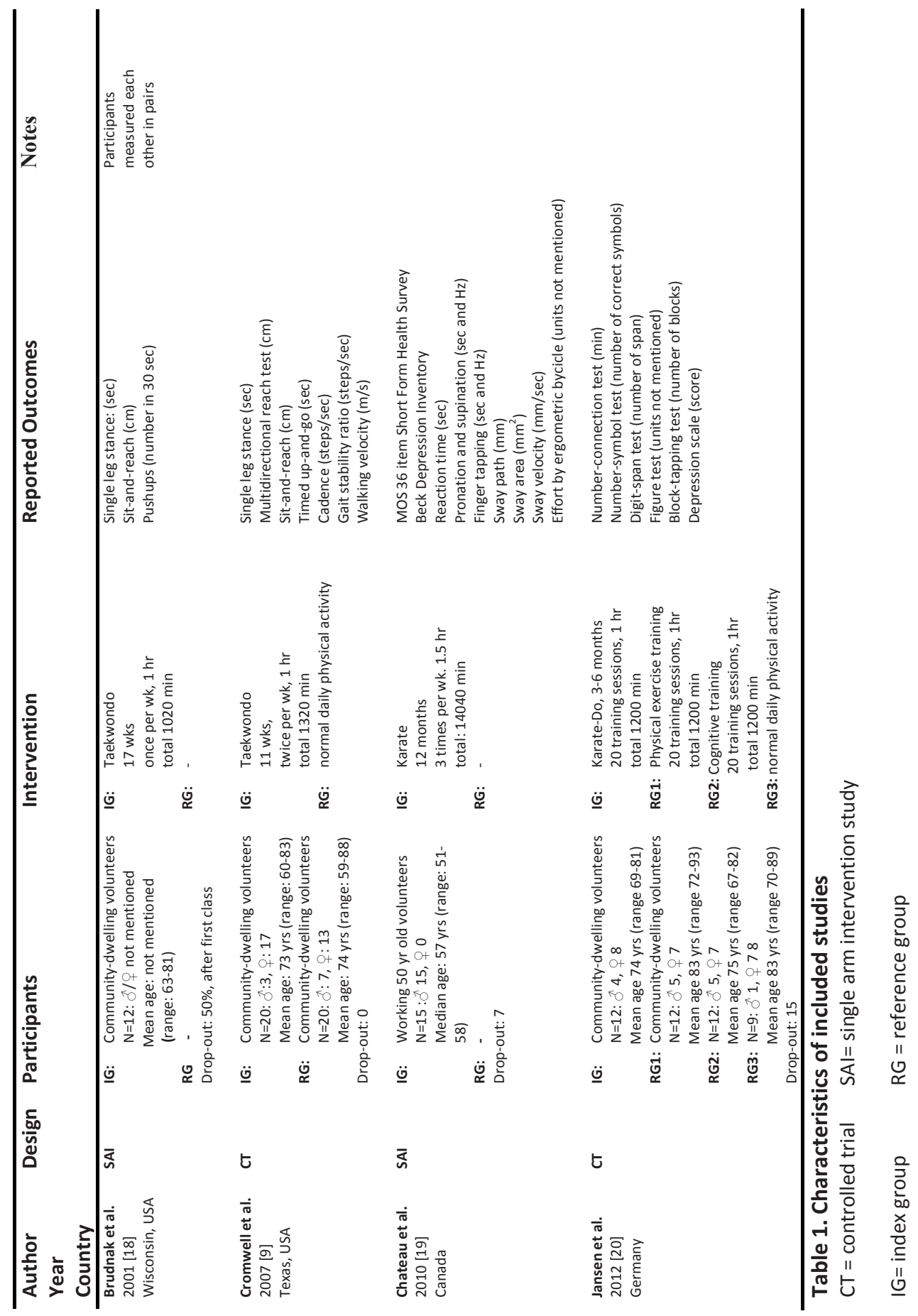




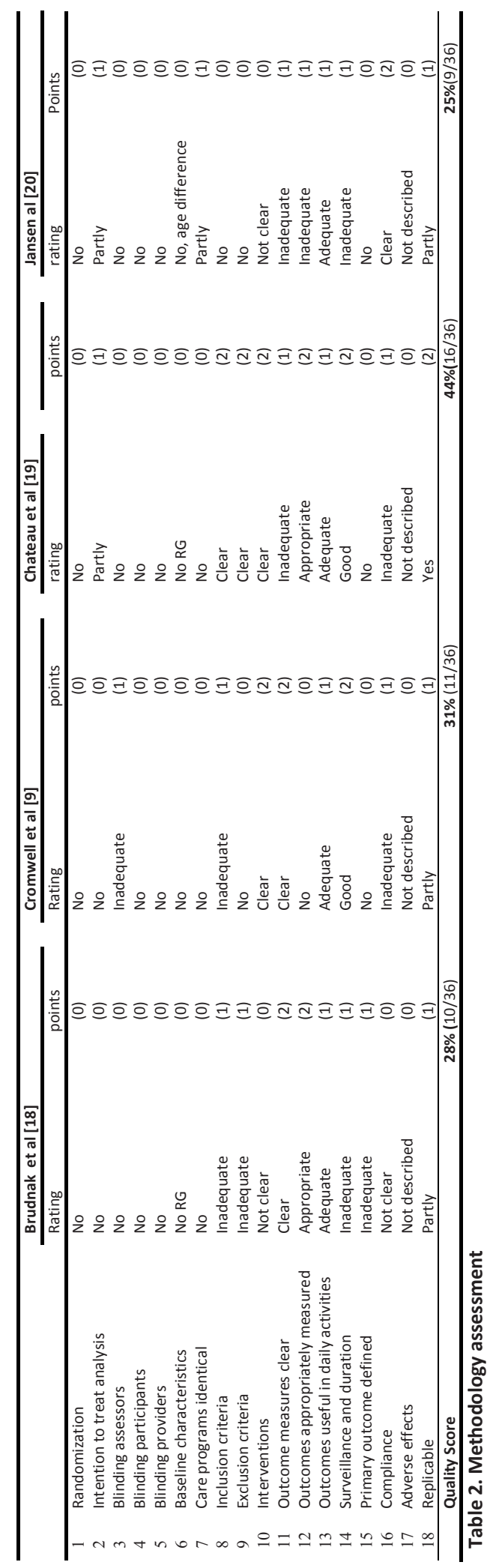


Methodological Characteristics

None of the studies had a randomized design. All the studies were performed after informed consent was given. See Table 2 for further details. An important confounder for outcome measures is compliance, which in Cromwell et al. it is not mentioned ${ }^{9}$, whereas in Brudnak et al. there was a drop-out rate of more than 50\% after the first class ${ }^{18}$. Chateau-Degat et al. had a drop-out of 7 of 15 participants, whereas the attendance rate of the classes was not mentioned ${ }^{19}$. Jansen et al.

mentioned the drop-outs before study start. The reference group in that study had fewer training sessions than the other groups ${ }^{20}$.

Brudnak et al. measured one group of volunteers which functioned as their own reference group. There was no blinding since there was only one group and participants measured each other. In- and exclusion criteria were not well described; the authors did not explain why from the 27 recruited participants only 12 could continue with the study. Furthermore they describe an initial drop-out rate of 50\%, but it remains unclear how many participants did complete the intended number of the Tae Kwon Do classes. In effect on this indistinct description the mean age is uncertain, the participant's gender was not mentioned. The measurements conducted are described, and reproducible, however the quality of the measurements is doubtful since the participants measured each other. The Taekwondo classes are barely described, and it is unclear designed. Compliance and adverse effects were not described. The methodological scoring list is added to the addendum 1 and summarized in Table 2, the study scores an overall quality score of 10 out of $36^{18}$.

Cromwell et al. formed the groups based on patient preferences, the baseline characteristics were not entirely similar, but did not differ much. A chi-square test was performed to confirm similarity of health status between the Taekwondo and reference groups. The observers who measured the groups were blinded, but clearly the participants were not. In- and exclusion criteria were not mentioned in detail. No sample size calculation was performed prior to the study. The pre- and post-test measurements were clearly described, could easily be repeated and were applicable in daily activities. The intervention (Taekwondo) was clearly defined. Possible drop-outs were not mentioned. The measures were analyzed using an ANOVA for repeated measures. Participation compliance was well described and accounted for in analysis. Adverse effects were not reported. Therefore, the overall quality score is low and is 11 out of 36 (Table 2$)^{9}$.

The study of Chateau-Degat et al. is a clinical trial which recruited 22 healthy 50 -year-old male volunteers, who attended adapted karate training, so there were no women enrolled. The training content was well described and adapted to the participants' ability. Blinding was not possible since there was no reference group. It is unclear who conducted the measurements and whether these were conducted by the same assessors at baseline, 6 months and 12 months. The in- and exclusions were clearly described. There was a post hoc power sample size calculation; the power was $86.1 \%$, and considered adequate. The measurements were well described, but the outcome data were not described completely and remain, therefore, partly unclear. Furthermore, not all the measurements, particularly those at 6 months, were mentioned, but were only illustrated in a diagram. The drop-outs were well described. The analysis was made by conventional $t$-test, with Fisher's exact tests comparing proportions or by the Mann-Whitney U-test. Compliance and adverse effects are not mentioned. There is an intermediate overall quality score of 16 out of 36 (Table 2) ${ }^{19}$. The study by Jansen et al. was a controlled intervention study. In total 45 older adults, ranging from 69 to 93 years of age, were enrolled. Inclusion and exclusion criteria were barely mentioned and not clear. A post hoc 
Bonferroni correction showed that the participants of the physical exercise and control group were significantly older than the participants in the other two groups. The intervention of the several groups was not described clearly. In particular, the content and intensity Karate training were vague. Although this was done "according to the German-Karate-Federation", how these were adapted to age was not described. Furthermore, outcome measurements were unclear and not rated blindly. As analysis they performed a univariate analysis of variance, and although some of the interactions were "statistically significant", this does not allow concluding that the intervention was causally related to the dependent variables. This all sums up to an overall quality score of 9 out of 36 (Table 2$)^{20}$.

\section{Outcome Measurements}

All the outcome measurements of the reviewed studies are listed in Table 3a-d.

\section{Analysis}

Our results show that all four included studies were of poor quality (score below 50\%).

\section{Table 3. Results}

\begin{tabular}{|c|c|c|c|}
\hline \multirow[b]{2}{*}{ Article } & \multirow[b]{2}{*}{ Measurement } & \multicolumn{2}{|l|}{$\begin{array}{l}\text { Index } \\
\text { Group }\end{array}$} \\
\hline & & $\begin{array}{l}\text { Pre } \\
\text { mean }\end{array}$ & $\begin{array}{l}\text { Post } \\
\text { mean }\end{array}$ \\
\hline Brudnak & Sit-and-reach $(\mathrm{cm})$ & Increase & $>8.9$ \\
\hline \multirow[t]{3}{*}{ [18] } & Pushups (number per $30 \mathrm{~s}$ ) & Increase & 1.8 \\
\hline & Single leg stance (s): Right & Increase & $>16$ \\
\hline & Left & Increase & 16 \\
\hline
\end{tabular}

Table 3a. Results of Brudnak et al. [18].

Pre= Before training Post $=$ After training

\section{Discussion and Conclusions}

Our aim was to do a systematic review of the available literature. Although our methods complied with this aim, both quality and quantity of the material we analyzed did not allow us to explicitly fulfill our original goal. The number of reviewed studies was limited, as was their methodological quality, which illustrates the lack of research in the area of health benefits of hard martial arts in people over 40 . We found four studies, which were all of a small size, whereas their intervention duration was rather short. Furthermore, there were large differences in study design, outcome measures, methodological quality, and character of training content. With only four studies found, one may consider a systemic review to be a bit premature. However, our review may make investigators well aware of the idea that further study is needed. The studies, nevertheless, suggest some benefit, and if proper studies could confirm beneficial effects of hard martial arts training, such training could eventually be recommended as a hopefully safe, pleasant and cheap way to maintain or even improve 


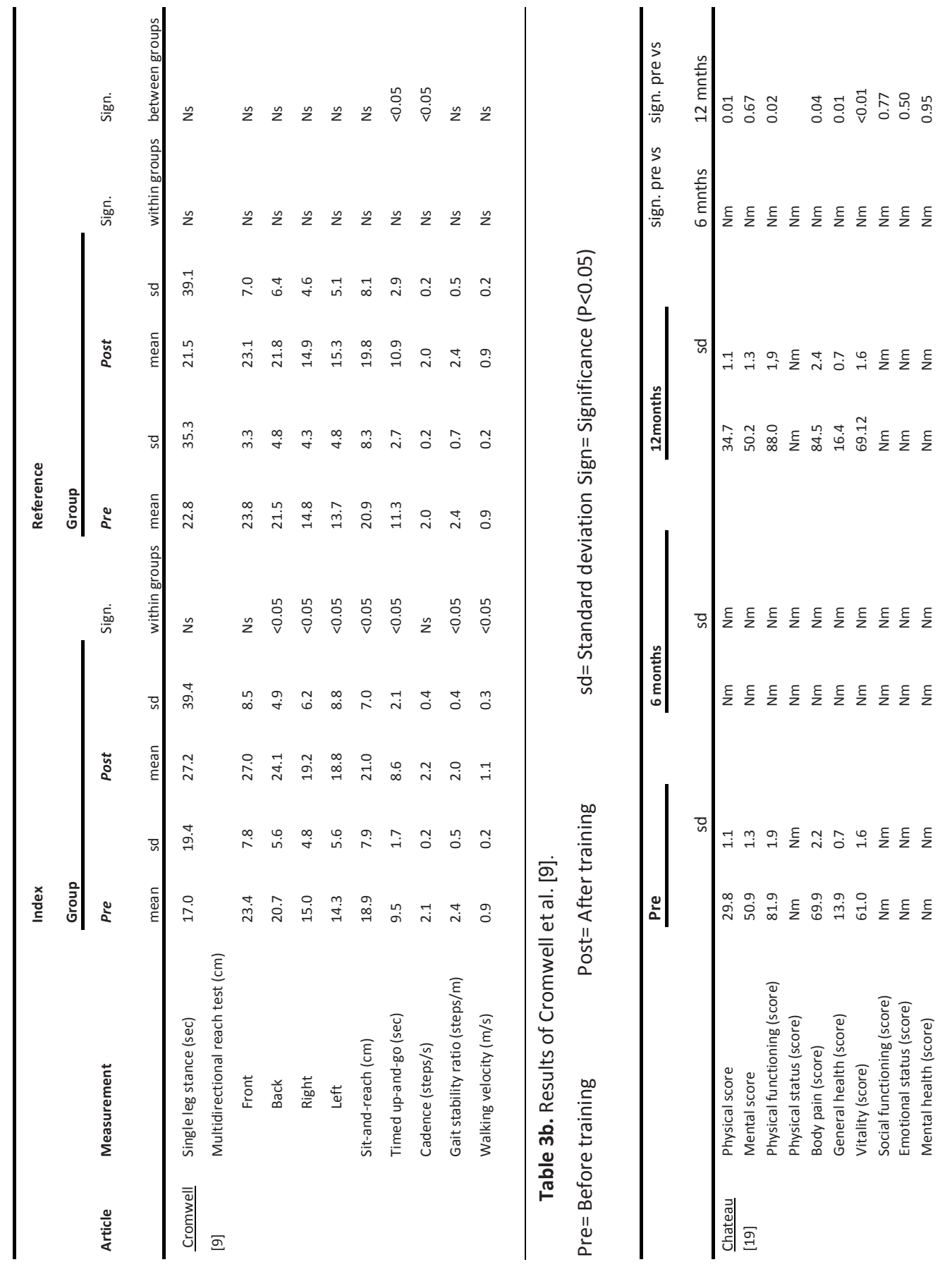




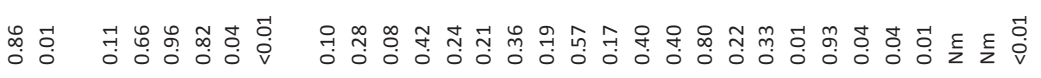

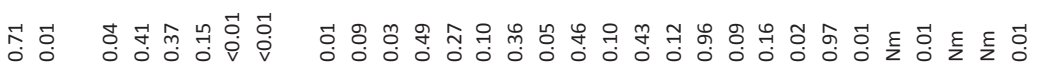

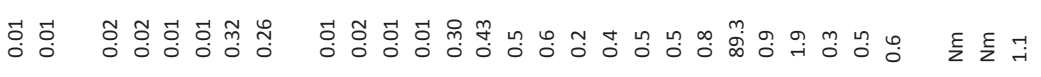

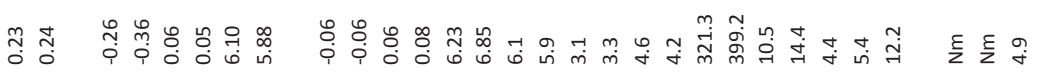

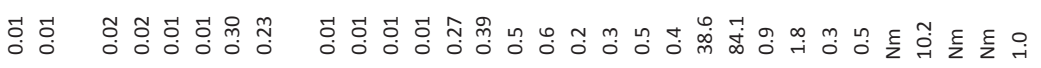

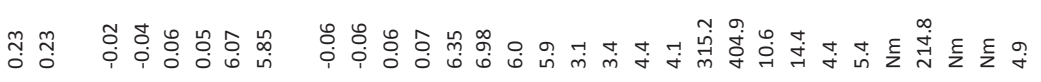

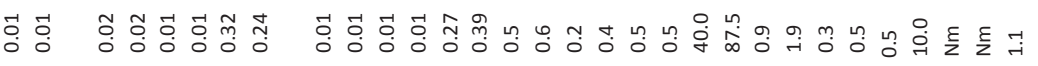

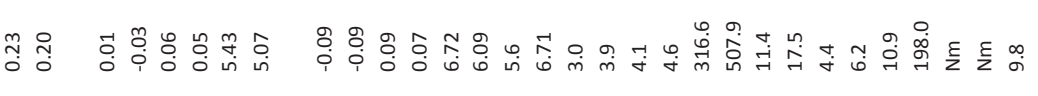

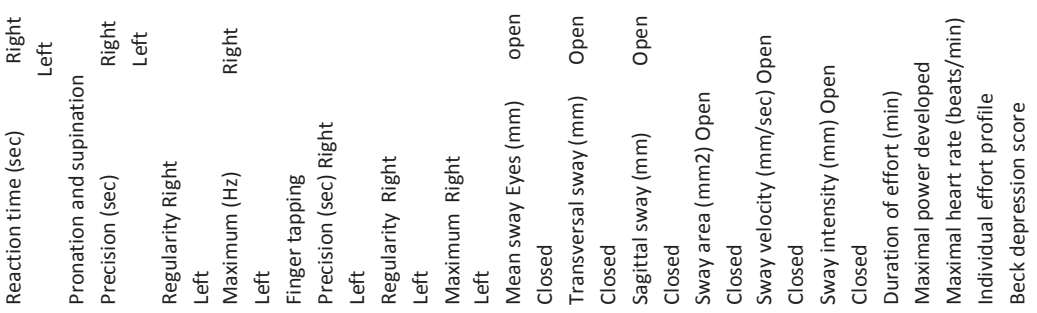




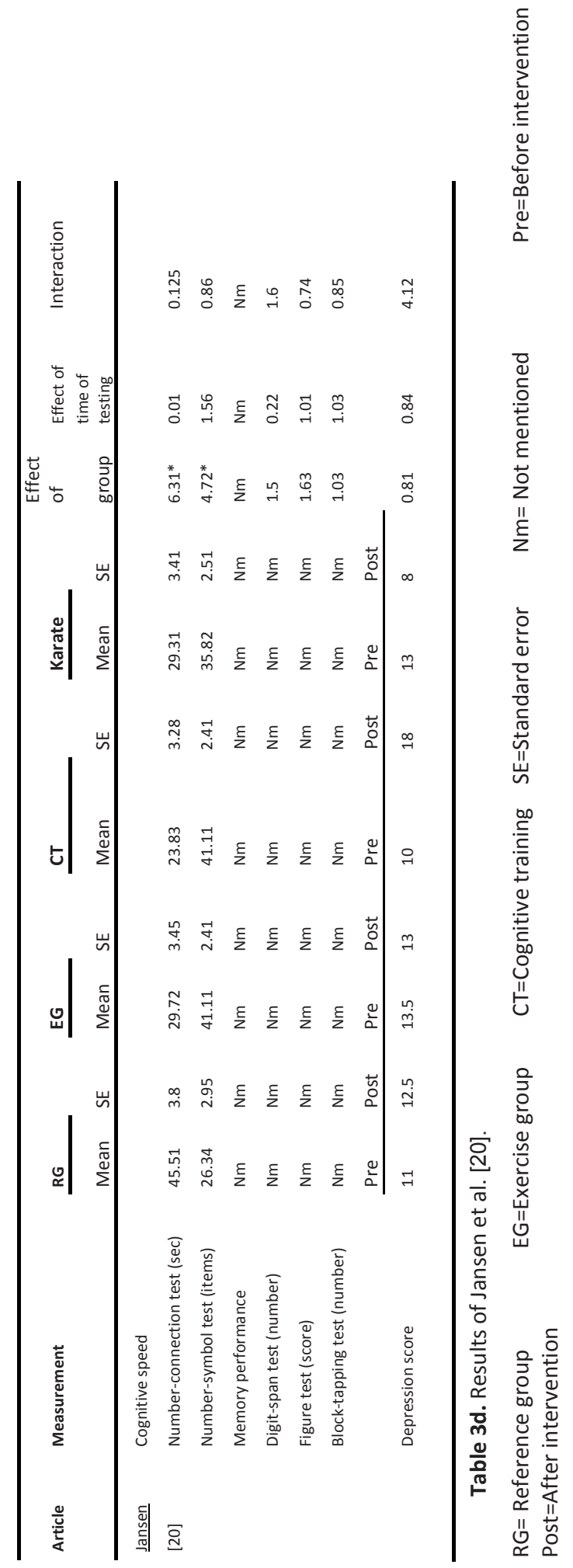


various physical fitness functions in people over 40 . Whether, or to what extent, benefits outweigh the risk of training injury cannot be inferred from the four studies, as neither injury frequency nor injury severity was reported. This is certainly an issue that should be included in any future studies. Preliminary data suggest that when training programming is adjusted to account for age-related requirements, training injuries are minor ${ }^{22}$. When looking at the proportion of ageing people in society who maintain a sedentary lifestyle, substantial gain in health on a societal level might be attained if this age group could be convinced to practice hard martial art forms. Such an approach could result in significant savings in healthcare costs at a minimal amount of investment. An important potential benefit may be the mitigation of age-related deterioration in mobility, which increases falls and jeopardizes self-maintenance, both of which are rather costly affairs for society, especially when the proportion of aged and very old people is on the increase ${ }^{4,6,13}$.

Subjective benefits from martial arts training is often reported, especially in (generally Asian) countries where the various arts originated. Without doubt we missed reports in the Asian languages, and we cannot exclude such a language bias in our survey. Originally we aimed to include Kung Fu as a hard martial art in our review, but the nine studies covered in a 2008 systematic review of health benefits of this art were all on younger age groups, whereas we were unable to find any later published study on an age group above $40^{23}$.

We excluded one study because it was a retrospective study and thus not an experimental design: Douris et al. investigated a group of martial arts practitioners and a reference group consisting of sedentary community members. The martial arts practitioners had participated in Soo Bahk Do training during three years or more, a minimum of twice a week for $1 \mathrm{~h}$ a day. All classes were led by a certified Soo Bahk Do instructor. The reference group did not engage in physical exercise other than normal daily activities. Single leg stance was significantly longer with $35 \mathrm{~s}$ more, the sit-and-reach test showed a difference of $11.8 \mathrm{~cm}$ in favor of the Soo Bahk Do group, with a $p$-value of $0.01^{17}$.

The Karate and Taekwondo studies incorporate straight line powerful blocking, kicking and punching techniques as a major exercise component. However, generally the rates of kicking techniques, often combined with turning and jumping movements, amount to about $75 \%$ of exercises in Taekwondo, but only $25 \%$ in Karate. Therefore, although these various styles are all listed as "hard" martial art, they differ quite substantially in technical content, and their effects on separate physical fitness components may also vary. Especially the practice of more dynamic movement patterns, such as practiced in Taekwondo, may stimulate balance function. The four studies listed in this paper also showed differences in training effects, but the numbers were too small for a reliable comparison.

From this review we may conclude that current evidence that hard martial arts practice improves physical fitness functions in healthy people over 40 is suggestive, but not convincing. Our analysis together with the consideration of the potential health and health cost benefit, leads us also to conclude that the subject warrants further study. New studies should be properly designed, report training programming, dose, and assessment, and also report on adverse events, whereas criteria for outcome assessment should clearly be described. Studies should have a set duration of the training intervention of probably at least one year, whereas they may focus not only on physical but also on 
cognitive aspects. Moreover, aspects such as safety, program feasibility, and long-term adherence should also be addressed. More reliable data are required before age-adapted hard martial art training in people over 40 can be recommended as a means to mitigate the age-related decline of various physical functions. 


\section{Appendixes}

\begin{tabular}{|c|c|c|c|}
\hline Item & & Points & Rating \\
\hline \multirow[t]{3}{*}{1.} & \multirow{3}{*}{$\begin{array}{l}\text { Was the assigned intervention adequately } \\
\text { concealed prior to allocation? }\end{array}$} & 2 & Method did not allow disclosure of assignment \\
\hline & & 1 & Small but possible chance of disclosure of assignment or unclear \\
\hline & & 0 & Quasi-randomized or open list/tables \\
\hline \multirow[t]{3}{*}{2.} & \multirow{3}{*}{$\begin{array}{l}\text { Were the outcomes of participants who } \\
\text { dropped out described and included in the } \\
\text { analysis (intention tot treat)? }\end{array}$} & 2 & Drop outs well described and accounted for in analysis \\
\hline & & 1 & Drop outs described and analysis is not possible \\
\hline & & 0 & No mention, inadequate mention or obvious differences and no adjustment \\
\hline \multirow[t]{3}{*}{3.} & \multirow{3}{*}{$\begin{array}{l}\text { Were the outcome assessors blinded to } \\
\text { intervention status? }\end{array}$} & 2 & Effective action taken to blind assessors \\
\hline & & 1 & Small or moderate chance of unblinding of assessors \\
\hline & & 0 & Not mentioned or not possible \\
\hline \multirow[t]{3}{*}{4.} & \multirow{3}{*}{$\begin{array}{l}\text { Were the participants blind to assignment } \\
\text { status after allocation? }\end{array}$} & 2 & Effective action taken to blind participants \\
\hline & & 1 & Small or moderate chance of unblinding of participants \\
\hline & & 0 & Not possible or not mentioned, or possible but not done \\
\hline \multirow[t]{3}{*}{5.} & \multirow{3}{*}{$\begin{array}{l}\text { Were the intervention providers blind to } \\
\text { assignment status? }\end{array}$} & 2 & Effective action taken to blind intervention providers \\
\hline & & 1 & Small or moderate chance of unblinding of intervention providers \\
\hline & & 0 & Not possible or not mentioned, or possible but not done \\
\hline \multirow[t]{3}{*}{6.} & \multirow{3}{*}{$\begin{array}{l}\text { Were the intervention and control group } \\
\text { comparable at entry? }\end{array}$} & 2 & Good comparability of groups, or confounding adequately adjusted for in analysis \\
\hline & & 1 & Confounding small; mentioned but not adjusted for \\
\hline & & 0 & Large potential for confounding, or not discussed \\
\hline \multirow[t]{3}{*}{7.} & \multirow{3}{*}{$\begin{array}{l}\text { Were care programs, other than the } \\
\text { intervention identical (co-intervention)? }\end{array}$} & 2 & Care programs clearly identical \\
\hline & & 1 & Clear but trivial differences \\
\hline & & 0 & Not mentioned or clear and important differences in care programs \\
\hline \multirow[t]{3}{*}{8.} & \multirow{3}{*}{$\begin{array}{l}\text { Were the inclusion criteria clearly defined, } \\
\text { appropriate selection of study participants, for } \\
\text { the purpose of the study? }\end{array}$} & 2 & Clearly defined \\
\hline & & 1 & Inadequately defined \\
\hline & & 0 & Not defined \\
\hline \multirow[t]{3}{*}{9.} & \multirow{3}{*}{$\begin{array}{l}\text { Were the exclusion criteria clearly defined, } \\
\text { appropriate selection of study participants, for } \\
\text { the purpose of the study? }\end{array}$} & 2 & Clearly defined \\
\hline & & 1 & Inadequately defined \\
\hline & & 0 & Not defined \\
\hline \multirow[t]{3}{*}{10.} & \multirow{3}{*}{$\begin{array}{l}\text { Were the interventions clearly defined and } \\
\text { appropriately applied? }\end{array}$} & 2 & Clearly defined interventions are applied with a standardized protocol \\
\hline & & 1 & Clearly defined interventions are applied but the application protocol is not standardized \\
\hline & & 0 & Intervention and/or application protocol are poorly or not defined \\
\hline 11. & Were the outcome measures used clearly & 2 & Clearly defined \\
\hline & defined? & 1 & Inadequately defined \\
\hline & & 0 & Not defined \\
\hline 12. & Were the outcome measures used & 2 & Appropriately measured \\
\hline & appropriately measured? & 1 & Inadequately measured \\
\hline & & 0 & Not defined \\
\hline 13. & Were test used in outcome assessment useful & 2 & Optimal \\
\hline & in daily activities? & 1 & Adequate \\
\hline & & 0 & Not defined, not adequate \\
\hline 14. & Was the surveillance active and of appropriate & 2 & Active surveillance and appropriate duration \\
\hline & duration? & 1 & Active surveillance, but inadequate duration \\
\hline & & 0 & Surveillance not active or not defined \\
\hline 15. & Were point estimates and measures of & 2 & Yes \\
\hline & variability presented for the primary outcome & 1 & Point estimates, but no measures of variability presented \\
\hline & measures? & 0 & Vague descriptions \\
\hline 16. & Was the compliance rate in each group likely & 2 & Compliance well described and accounted for in analysis \\
\hline & to cause bias? & 1 & Compliance well described but differences between groups not accounted for in analysis \\
\hline & & 0 & Compliance unclear \\
\hline 17. & Was there a description of adverse effects of & 2 & Well described \\
\hline & the intervention? & 1 & Poorly described \\
\hline & & 0 & Not described \\
\hline 18. & Is the intervention replicable and feasible? & 2 & Yes \\
\hline & & 1 & Partly \\
\hline & & 0 & No \\
\hline
\end{tabular}

Addendum A1. Quality rating (internal validity). 


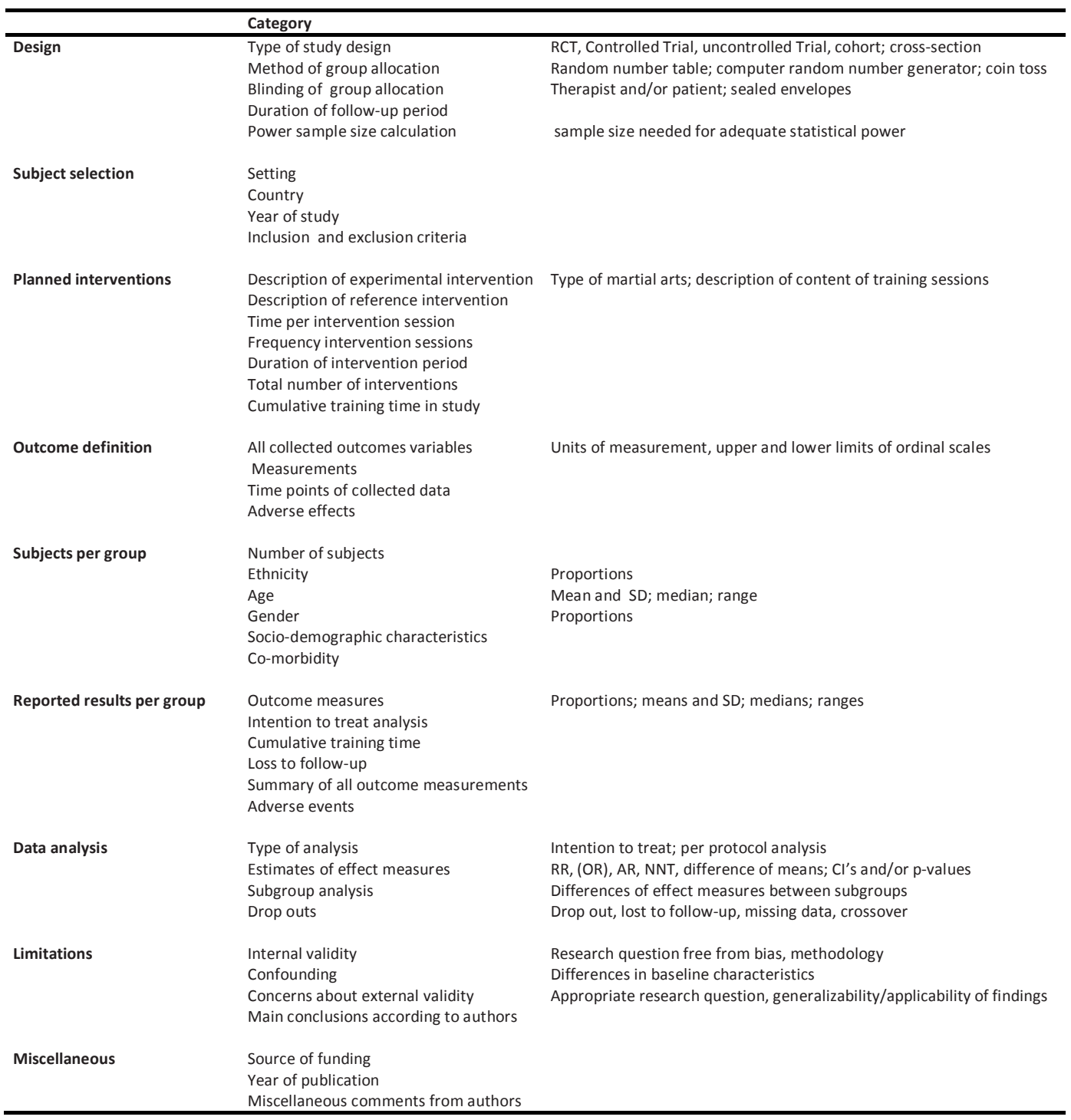

Addendum 2. Study description/characteristics inventory

$\begin{array}{ll}\mathrm{RCT}=\text { Randomized controlled trial } & \mathrm{SD}=\text { Standard deviation } \\ \mathrm{NNT}=\text { Number needed to treat } & \mathrm{Cl}=\text { Confidence interval }\end{array}$




\section{References}

1. American College of Sports Medicine. Acms's Resource Manual for Guidelines for Exercise Testing and Prescription, 6th ed.; Lippincott Williams and Wilkins: Philadelphia, PA, USA, 2001; pp. 57-90.

2. Kroes, G.; Greef de M. National initiatives for the promotion of physical activity for older persons in the netherlands. J. Aging Phys. Act 2000, 8, 431-435.

3. Lobstein, T.; Rigby, N.; Leach, R. EU platform on diet, physical activity and health. Available online:

http://ec.europa.eu/health/ph_determinants/life_style/nutrition/documents/iotf_en.pdf (accessed on march 15, 2005).

4. Cress, M.E; Buchner, D.M.; Questad, K.A.; Esselman, P.C.; de Lateur, B.J.; Schwartz, R.S.A. Exercise: Effects on physical functional performance in independent older adults. J Gerontol. Med. Sci. 1995, 54A, 242-248.

5. Buchner, D.; Cress, M.E.; de Lateur, B.J.; Esselman, P.C.; Margherita, A.J.; Price, R.; Wagner, E.H. A comparison of the effects of three types of endurance training on balance and other fall risk factors in older adults. Aging Clin. Exp. Res. 1997, 9, 112-119.

6. Cameron, I.D.; Gillespie, L.D.; Robertson, M.C.; Murray, G.R.; Hill, K.D.; Cumming, R.G.; Kerse, N. Interventions for preventing falls in older people in care facilities and hospitals. Cochrane Database Syst. Rev. 2012, 12, doi:10.1002/14651858.CD005465.pub3.

7. Rubenstein, L.Z.; Josephson, K.R. The epidemiology of falls and syncope. Clin. Geriatr. Med. 2002, 18, 141-158.

8. Hausdorff, J.M.; Rios, D.A.; Edelber, H.K. Gait variability and fall risk in community-living older adults: A 1-year prospective study. Arch. Phys. Med. Rehabil. 2001, 82, 1050-1056.

9. Cromwell, R.L.; Meyers P.M.; Meyers, P.E.; Newton, R.A. Taekwondo: An effective exercise for improving balance and walking ability in older adults. J. Gerontol.: Med. Sci. 2007, 62A, 641-646.

10. Gauchard, G.C.; Gangloff, P.; Jeandel, C.; Perrin, P.P. Influence of regular proprioceptive and bioenergetic physical activities on balance control in elderly women. J. Gerontol. A Biol. Sci. Med. Sci. 2003, 58, 846-850.

11. Corcoran, J.; Farkas, E.; Sobel, S. The Original Martial Arts Encyclopedia: Tradition, History, Pioneers; Pro-Action Publications: Los Angeles,USA, 1993.

12. Alexandrov, A.; Frolov, A.A.; Massion, J. Biomechanical analysis of movement strategies in human forward trunk bending. I. Modeling. Biol. Cybern. 2001, 84, 425-434.

13. Fong, SS.; Ng, G.Y. Does taekwondo training improve physical fitness? Phys. Ther. Sport 2011, $12,100-106$.

14. Verhagen, A.P.; de Vet, H.C.; de Bie, R.A.; Kessels, A.G.; Boers, M.; Bouter, L.M.; Knipschild, P.G. The delphi list: A criteria list for quality assessment of randomized clinical trials for conducting systematic reviews developed by delphi consensus. J. Clin. Epidemiol. 1998, 51, 1235-1241.

15. Li, Y.; Devault, C.N.; van Oteghen, S. Effects of extended tai chi intervention on balance and selected motor functions of the elderly. Am. J. Chin. Med. 2007, 35, 383-391. 
16. Pons van Dijk, G.; Lenssen, A.F.; Leffers, P.; Kingma, H.; Lodder, J. Taekwondo training improves balance in volunteers over forty. Front. Aging Neurosci. 2013, 5, 10. doi:10.3389/fnagi.2013.00010.

17. Douris, P.; Chinan, A.; Gomez, M.; Aw, A.; Steffens, D.; Weiss, S. Fitness levels of middle aged martial art practicioners. Br. J. Sports Med. 2004, 38, 143-147.

18. Brudnak, M.A.; Dundero, D.; van Hecke, F.M. Are the "hard" martial arts, such as the korean martial art, taekwon-do, of benefit to senior citizens? Med. Hypotheses 2002, 59, 485-491.

19. Chateau-Degat, M.-L.; Papouin, G.; Saint-Val, P.; Lopez, A. Effect of adapted karate training on quality of life and body balance in 50-year-old men. Open Access J. Sports Med. 2010, 1, 143-150.

20. Jansen, P.; Dahmen-Zimmer, K. Effects of cognitive, motor, and karate training on cognitive functioning and emotional well-being of elderly people. Front. Psychol. 2012, 3, 40. doi:10.3389/fpsyg.2012.00040.

21. Leplege, A.; Ecosse, E.; Pouchot, J.; Coste, J.; Perneger, T. Le questionnaire MOS SF-36: Manuel de L'itilisateur et Guide de L'interpretation des Scores; Editions Estem: Paris, France, 2001.

22. Pons van Dijk, G.; Leffers, P.; Lodder, J. Feasibility, safety and subjective experience of a one-year WTF-Taekwondo training course for middle-aged volunteers: The Sekwondo study. Gazz. Med. Ital. Arch. Sci. Med. 2013, 172, 433-441.

23. Tsang, T.W.; Kohn, M.; Chow, C.M.; Singh, M.F. Health benefits of kung fu: A systematic review. J. Sports Sci. 2008, 26, 1249-1267. 


\section{2}

Feasibility, safety and subjective experience of a one-year WTF-Taekwondo training course for middle-aged volunteers; the Sekwondo study

G. Pons van Dijk, P. Leffers and J. Lodder 


\section{Abstract}

Aim of the study: to investigate in middle-aged healthy volunteers the feasibility, safety, and subjective experience of age-adapted Taekwondo training of one hour a week during one year.

Methods: single arm intervention study with each participant serving as his or her own control. Study population: 24 healthy volunteers, 40-71 years of age. As a measure of program feasibility, we counted study dropouts and program non-compliers, and registered the reasons for withdrawal. To describe safety we measured and listed all training related injuries. Subjective assessment of training effects by participants was carried out by means of a questionnaire.

Results: five participants withdrew from the training program, but all 24 had baseline and final measurements; three withdrew because of the program content and the complexity of the Taekwondo exercises. We offered 60 sessions and allowed additional training at the trainers' Taekwondo club. The 19 participants who completed the study followed a median of 39 training sessions (range: 25-67). There were five (non-serious) training related injuries, which equals 5.7 per 1000 athlete exposures (AE) (confidence interval: 4-8/1000). Subjective benefits in the 19 study completers were on: physical fitness (9), mental fitness (5), self-confidence (6), and mood (4). Eighteen participants adhered to the program because it was experienced as fun even though two of these reported persistent minor ailments as a consequence of training.

Conclusion: long-term age-adapted Taekwondo training is feasible in middle-aged, healthy persons. It can be safely executed, whereas it is experienced as fun and subjectively judged beneficial by most. Age-adjusted Taekwondo should be listed among the sports from which middle-aged people can choose to increase their physical exercise. 


\section{Introduction}

Many people lack sufficient daily physical exercise, while some have almost none ${ }^{1,2}$. A low level of regular physical exercise increases the risk of cardiovascular disease, diabetes mellitus, and osteoporosis, whereas it has a negative impact on mood, cognitive functions, mobility, and overall wellbeing. These negative consequences increase with age, resulting in an elevated risk of premature loss of autonomy ${ }^{1,3-5}$. In particular, aspects of dynamic loco-motor functioning decrease with increasing age: steps become shorter, walking pace decreases, whereas the time that both feet touch the ground during walking and turning increases ${ }^{6-10}$.

Exercise programs, some of which were based on one of the martial arts, seem to improve various locomotor components in the elderly ${ }^{5,11-23}$. Compared to other martial arts Taekwondo contains more highly dynamic movement patterns. Therefore, middle-aged or elderly may sustain the largest benefit from Taekwondo-based training with regard to dynamic loco-motor functioning, including dynamic balance. If proven effective such program could potentially offer a cheap method to improve locomotor skills of the middle-aged and elderly, and consequently reduce the age-related loss of selfmaintenance in the general population. Furthermore, Taekwondo is being practiced in over 170 countries worldwide, and has millions of practitioners, most of whom, however, are young. Therefore, Taekwondo training is rather accessible to most elderly adults who would decide to increase their physical exercise with the main idea to improve their health. However, it is unclear whether people of this age group can persevere in long-term Taekwondo-based training, and whether such training is safe. Program duration in two Taekwondo-based studies published so far was short, the numbers of subjects and studied parameters were small, the number of dropouts unclear, while possible injuries were not reported ${ }^{11,24}$. Consequently, it is still unclear whether Taekwondo-based training in middle-aged people is feasible and safe.

Therefore, we performed a study in seniors to measure the feasibility of such training program as inferred from the number (and reasons) of dropouts and from the incidence and severity of injuries. Secondly, we report whether such training is fun rather than tedious, and whether it carries personal benefit as measured by the participants' reported subjective evaluation.

\section{Participants and methods}

The study was designed as a single arm intervention study in which participants served as their own control.

Study population: Healthy male and female volunteers, 40-75 years of age.

Inclusion criteria: Willingness to follow at least a one hour Taekwondo training session weekly. All volunteers had a routine neurological and cardiologic physical investigation and an exercise ECG. Volunteers would be excluded if there was any doubt about eligibility. 
Exclusion criteria: Current psychiatric treatment. The use of oral anticoagulants. Any disease that was expected to interfere with training, as judged by the volunteer's treating physician, the study neurologist (JL), or study cardiologist.

Recruitment and consent: Posters inviting people for participation were posted at various locations in the Maastricht Hospital and the University. Interested people were informed by oral and written information, and they were encouraged to follow at least two Taekwondo sessions at the trainers' Taekwondo club before enrolment.

Study measurements took place in the month before the start of the study, and as soon as possible after the last training session. At baseline we recorded: gender, age, level of education, body weight and height, current smoking status, and current time spent on sport activities in hours/week. The last four items were recorded again at the end of the study.

A questionnaire on the participants' subjective assessment on various aspects of the program was filled out three months after study onset, and at its end.

Adverse effects and injuries were documented, without any predefined type or threshold of severity.

Sample size estimation. An estimated number of 17 needed subjects was based on assumptions regarding the effect of training on the principle outcome parameter of the study (which was an integrated measure for the quality of balance ${ }^{25}$. For full protocol description see the internet link under ethical considerations below). Considering seven possible dropouts, we decided to include 24 persons.

Training sessions: Training intensity was adjusted to the participants' physical condition, and adapted over time. The sessions lasted about one hour, and generally consisted of the following elements: a short warming-up; Taekwondo techniques, such as stances, blockings, kicks, punches, and strikes; poomsae, or style figures, which are fixed patterns, illustrating a fight against one or more imaginary opponents; some elementary self-defense Taekwondo techniques. As Taekwondo combat sparring was considered injury prone, such practice was not included. We practiced the style of the World Taekwondo Federation (www.WTF.org), and in accord with the guidelines offered by the World Taekwondo Headquarters, Kukkiwon, which is the official South Korean governmental Taekwondo governing organization (www.Kukkiwon.org). We wrote each week's training program in advance as a training script, taking account of both the overall aims of the project and the volunteers' ability to cope with gradually increasing training intensity and complexity. Participants were advised to daily perform some simple balance exercises for five to ten minutes, and also to practice some simple stretching exercises. After each training session, we sent an e-mail letter to all participants with a reflection of the latest training session, a preview of the next one, and an invitation to make any comments on any aspect of the program.

The first training session took place on 21 October 2009, and the final one on 19 January 2011. We aimed at 40 lessons for each participant within one year, but because the attendance rate was lower than anticipated, we decided to extent the training period with three months. During the study, several participants chose to follow additional Taekwondo lessons at our Taekwondo club facility 
(www.chun-ji.be). We adapted the club training program to comply with the study protocol when study participants attended club trainings. Number of lessons at the two locations was recorded separately.

Withdrawal: Subjects were encouraged to continue participation, but they could leave the study at any time without any obligation to reveal their reasons. However, we listed reasons for dropping out to evaluate the feasibility of the training program. We encouraged study participation by creating an informal atmosphere, and we reserved ample time for feedback.

Statistical analysis: Continuous data are summarized as average or median and range, and dichotomous variables as percentages.

Ethical considerations: The study was conducted according to the principles of the Declaration of Helsinki, and in accordance with the Dutch Medical Research Involving Human Subjects Act (WMO). It was approved by the University Hospital Maastricht Ethical Committee and listed before study onset in the linked, Dutch Trial Registry: www.trialregister.nl/trialreg/admin/rctsearch.asp under the acronym "SEKWONDO Study".

\section{Results}

There were 12 men and 12 women; median age was 57 (range: 41-71) years. Fifteen participants had a university education, eight a higher vocation, and one a lower vocation. Table 1 shows the remaining participants' characteristics at study onset and end. Thirteen participants (two non-compliers) had higher BMI at study end, four (one) had unchanged, and four (two) had a lower BMI. One of six smokers stopped smoking during the study. Three participants (one non-complier) had started extra sport activities besides the study training sessions.

\begin{tabular}{|c|c|c|}
\hline & Start & Finish \\
\hline BMI, median (range) & $24.7(20.2-33.7)$ & $24.7(22.1-33.7)$ \\
\hline Smokers, $\mathrm{n}$ & 6 & 5 \\
\hline Median (range)* & $8 \quad(5-20)$ & $10 \quad(5-20)$ \\
\hline Additional sport(s), $n$ & 18 & 21 \\
\hline Median (range) $* *$ & $5 \quad(1-15)$ & $5 \quad(1-15)$ \\
\hline
\end{tabular}

Table 1. Characteristics of 24 participants.

* Number of daily cigarettes/cigars, **hours per week

Dropouts: All participants had all baseline and final measurements, so there were no study dropouts. However, three women and two men withdrew early from the training program (non-compliers). After four training sessions, a 59-year-old male participant sustained an acute annoying pain in the right groin area while playing soccer with his children. Before complete recovery he accepted a demanding 
appointment which left him unable to further attend the training sessions. After 17 training sessions a 51-year-old female decided to leave the project because she found it very difficult to master the various movement patterns despite her dedicated training. After 17 training sessions, a 44-year-old female quit because she could no longer combine the training with the obligation to attend to the needs of a relative. After 14 training sessions a 61-year-old male decided to leave the project because he found it very difficult to master the various movement patterns despite dedicated training. His decision came after he had skipped several lessons due to pain in both knees which he attributed to kicking exercises. After 21 training sessions, a 63-year-old female quit for two reasons: she was progressively unable to attend the training due to professional obligations, whereas she additionally loathed the quasi aggressive nature of the loud shouting that accompanies many Taekwondo techniques. So, in two participants the reason to stop training was training-related, in two due to external reasons, and in the fifth a combination of both. In no case was training-related injury a direct and only reason for discontinuation. Demographic data were quite similar between the five non-compliers and those completing in the study.

\begin{tabular}{lcccccc}
\hline \multicolumn{3}{c}{ All $(\mathrm{n}=24)$} & \multicolumn{3}{c}{$\begin{array}{c}\text { Completers } \\
(\mathrm{n}=19)\end{array}$} \\
\hline & Median & Range & Total Hours & Median & Range & Total Hours \\
Study facility & 34 & $4-44$ & 745 & 37 & $24-45$ & 672 \\
Club facility & 12 & $2-24$ & 129 & 11 & $2-24$ & 125 \\
Combined & 38 & $4-97$ & 874 & 39 & $25-67$ & 797 \\
\hline
\end{tabular}

Table 2. Frequency of participation in training sessions and total amount of time trained in different locations, for all participants and study completers separately.

\begin{tabular}{lccccc}
\hline Since starting the study training: & much worse & worse & unchanged & better & much better \\
\hline my feeling of physical fitness is & 0 & 1 & $9(4)$ & $9(1)$ & 0 \\
my mental fitness is & 0 & 1 & $13(5)$ & 5 & 0 \\
my self-confidence is & 0 & 0 & $13(5)$ & 6 & 0 \\
my mood is & 0 & 1 & $14(4)$ & $4(1)$ & 0 \\
am I troubled by minor physical ailments & 0 & 2 & $15(3)$ & 2 & 0 \\
\hline
\end{tabular}

Table 3. Subjective assessment of Taekwondo training effects in the 19 participants who completed the study (five non-completers).

Number of training sessions: Table 2 shows the total number of person-hour time of training sessions and median number of training sessions (with range) at the study facility and at the trainers' club. Data are listed separately for all participants and those who completed the study. The average number of sessions for the 19 completers was 42 . There were 60 training sessions at the study facility, which 
equals $19 \times 60=1140$ person-hour of potential training time. The 19 actually had 672 person-hour of training. Therefore, their average attendance rate at the formal study's primary training site was $59 \%$. Including Taekwondo club training sessions, the total training time for the 19 was 797 person-hours and 874 when the non-compliers are included. Ten of the 19 completers had fewer (average 35) than the projected number of 40 lessons. The nine who did attain at least 40 sessions had an average close to 50 . Table 3 shows the data on the participants' subjective assessment of the effect of the training program at the end of the study. One person scored "worse" on all but one item. Table 4 shows the answers by the 19 participants who completed the training program to the questions on various training characteristics. The three reported minor restrictions were: "some pain sometimes here and there", "wished my physical condition was better", "some shoulder pain". Four reported moderate restrictions: "limited flexibility" by two, "movements in the hip joints are really painful sometimes", "painful movements in many joints". One reported a serious restriction due to pain in the right foot following a training-related injury which was a fissure in one of the metatarsal bones. Eventually, four months after the study training program was discontinued, nine study completers had joined our regular Taekwondo club trainings.

Training related injuries: Altogether ten participants sustained some kind of physical activity related injury for which most of them had to skip one or more training sessions. In four the injury was directly related to the Taekwondo training activities: 1) pain in a knee following a round house kick against a kicking pad, 2) some pain in both knees, 3) major pain in the right foot due to a metatarsal bone fissure following kicking against a kicking pad, 4) the big toe nail partially torn from the nail bed due to a kick against a kicking pad. Five participants sustained injuries outside the study trainings: 1) the above described first non-complier case, 2) slightly sprained ankle due to a fall from the stairs, 3) serious left shoulder concussion and fracture of the upper arm bone due to a fall on the ice during ice skating, 4) acute lumbago from working in the garden, 5) serious left shoulder concussion with bone fracture due to a fall from a ladder during fruit picking. In one case most likely both training- and non-trainingrelated injuries played a role: diffuse pain in various joints for which the participant blamed the trainings, but there were various other reasons in the private and professional domains that likely attributed to the complaints. Counting five training related injuries, which occurred in 874 person-hour training sessions, equals 5.7 per 1000 hours (95\% Cl: 4-8/1000).

\section{Discussion}

Our results show that Taekwondo training is feasible in middle-aged, healthy persons. Most of these found their physical capacity to participate, to learn new techniques, and their progress over time quite satisfactory. We had no loss to follow-up, but five participants withdrew from training prematurely; two for external reasons, two for reasons specifically related to the training, and in one, both types of reason played a role. During the design of the study, we had expected a maximum of seven dropouts, which we supposed to be related to the steady increase in complexity and intensity of the exercises, 


\begin{tabular}{|c|c|c|}
\hline & at three months & end of study \\
\hline \multicolumn{3}{|l|}{ Time of the day for lessons $(05.00-06.00 \mathrm{pm})$ : } \\
\hline too early & 2 & 2 \\
\hline just right & 17 & 17 \\
\hline too late & 0 & 0 \\
\hline \multicolumn{3}{|l|}{ Structure of lessons: } \\
\hline Clear & 19 & 19 \\
\hline not clear & 0 & 0 \\
\hline \multicolumn{3}{|l|}{ Pace of introducing new elements: } \\
\hline too slow & 1 & 2 \\
\hline just right & 15 & 16 \\
\hline too fast & 3 & 1 \\
\hline \multicolumn{3}{|l|}{ Learning techniques was easier: } \\
\hline with whole class & 0 & 1 \\
\hline in small groups & 19 & 14 \\
\hline Indifferent & 0 & 4 \\
\hline \multicolumn{3}{|l|}{ Duration of lessons should preferably be: } \\
\hline Shorter & 0 & 0 \\
\hline Unchanged & 13 & 17 \\
\hline Longer & 6 & 2 \\
\hline \multicolumn{3}{|c|}{ Understanding explanation of techniques, relative to expectation: } \\
\hline Easier & 2 & 2 \\
\hline as expected & 13 & 14 \\
\hline more difficult & 4 & 3 \\
\hline \multicolumn{3}{|l|}{ Intensity of warming-up, relative to expectation: } \\
\hline Lighter & 5 & 8 \\
\hline as expected & 11 & 11 \\
\hline Heavier & 3 & 0 \\
\hline \multicolumn{3}{|c|}{ Required physical effort during lessons, relative to expectation: } \\
\hline Lighter & 4 & 6 \\
\hline as expected & 13 & 13 \\
\hline Heavier & 2 & 0 \\
\hline \multicolumn{3}{|c|}{ Considering own physical ability, lessons should preferably be: } \\
\hline Lighter & 0 & 1 \\
\hline Unchanged & 12 & 7 \\
\hline Heavier & 7 & 11 \\
\hline \multicolumn{3}{|c|}{ Ease of learning Taekwondo techniques, relative to expectation: } \\
\hline Easier & 2 & 0 \\
\hline as expected & 6 & 10 \\
\hline more difficult & 11 & 9 \\
\hline \multicolumn{3}{|c|}{ Pace of own technical progress, relative to expectation: } \\
\hline Slower & 3 & 4 \\
\hline as expected & 11 & 10 \\
\hline Faster & 5 & 5 \\
\hline \multicolumn{3}{|l|}{ I attend sessions (multiple answers allowed:) } \\
\hline with reluctance & 0 & 0 \\
\hline because I consented to & 3 & 4 \\
\hline because they offer physically benefit & 11 & 9 \\
\hline because I enjoy it & 19 & 18 \\
\hline \multicolumn{3}{|c|}{$\begin{array}{l}\text { Severity of limitation to learn Taekwondo techniques because of physical } \\
\text { restrictions: }\end{array}$} \\
\hline none (no restrictions) & 10 & \\
\hline Slight & 3 & \\
\hline Moderately & 4 & \\
\hline Severe & 1 & \\
\hline
\end{tabular}

Table 4. Questionnaire on various training characteristics; answers of 19 participants who completed the training program 
although this reason was rarely reported in earlier publications. The study of Cromwell et al did not report on dropouts ${ }^{11}$. Brudnak et al recruited 27 subjects of whom eventually 12 were selected ${ }^{24}$. Six of these 12 left the program already following the first training session. How many of the remaining six participated subsequently in the study and for how long, was not clear. The difference in dropout/noncomplier figures between Brudnak's study (at least 50 per cent) and ours (20 per cent) may relate to our use of introductory training sessions as part of the selection procedure.

Generally, a well-balanced relation between personal capacity (level of skill) and demand from outside (exercise difficulty) is required for training adherence, as people may otherwise become frustrated. When demands are too high, feelings of incompetence may arise, whereas participants may become bored when demands are below their capacity ${ }^{26}$. Obviously, the curriculum we offered abided well by this principle. We might even have increased the intensity of the training sessions, as at the end of the study 11 of the 19 study completers found that training intensity might have been higher. Despite the fact that nine of the 19 completers reported to experience certain annoying physical restrictions which interfered with their success of training, all nine adhered to the training program. Furthermore, eight of these reported the program as "fun". Two important other reasons may have influenced study adherence: one is that we had a team of four instructors which allowed us to sometimes teach in small groups. This approach was highly appreciated by the participants. The second reason is that the sessions were obviously experienced as fun. A third reason may be that adults may value improvement or at least consolidation of their health. Two earlier Taekwondo intervention studies suggested such improvement ${ }^{11,24}$. Reporting on objective health related effects is not the aim of the present paper. However, our participants' personal reporting showed that about one third experienced improvement in their feeling of physical fitness, and about a quarter reported improved mental fitness, selfconfidence or mood. The idea that middle-aged people may appreciate Taekwondo training is further supported by our finding that nine of the study participants joined a Taekwondo club.

An important condition for Taekwondo training programs in the middle-aged or elderly is that such programs should be safe. We found 5.7 injuries per 1000 training sessions. We cannot compare our figures with those of the two earlier studies, because these did not mention injuries ${ }^{11,24}$. It has been recommended to report sports injury frequency as number per so-called athlete exposures (AE) ${ }^{27}$. An $A E$ could be a competitive match or a training session which, however, depending on the type of sport may considerably vary in duration, intensity, or both. In the literature, we found only injury data on Taekwondo competitive sparring. In a meta-analysis of 14 prospective studies Lystad et al. calculated an overall injury rate of 79.3 per $1000 \mathrm{AE} ;{ }^{28}$ where one AE in Taekwondo competitive sparring corresponds to a match of usually three times two-minutes of person-to-person combat. The authors concluded that most injuries were "of minimal severity" although 5.4 per 1000AE were brain concussions. Although the risks of competitive Taekwondo sparring does not reflect that of training sessions, these are high figures when compared to data from other sports as reported by Hootman et al. In a 16-year National Collegiate Athletic Association injury surveillance in 15 sports these authors found practice or training injury rates to vary between various sports from 1.9 and 9.6 per $1000 \mathrm{AE}^{29}$. 
For competitive engagements, they reported higher rates, varying between 4.3 and 35.9 per 1000AE. If we extrapolate

the reported difference between training and competition related injury rates in general to the reported Taekwondo sparring data, then training in this sport would still yield a rather high injury rate of somewhere between 15 and 26 per 1000AE. Considering such figures we may conclude that teaching age-adapted Taekwondo in middle-aged people, as we did in the SEKWONDO Study, is rather safe. However, the training of combat sparring should be avoided in the training of older adults.

Our study has some drawbacks. Firstly, our aim of participation in 40 training sessions of approximately 60 organized sessions (which equals $67 \%$ adherence) was too optimistic. We based our expectations on the study by Cromwell et al, who reported an attendance rate of 70 per cent ${ }^{11}$. However, most of the participants in that study were probably retired people as their age (average 72.7 year) was higher than that of our population (average 56). One of the main reasons for not-attending was incompatibility of the moment of the training session with professional obligations well beyond office hours. This was most probably often related to the medical and/or academic professions of a large part of the participants, and therefore not related to the contents of the program. Unfortunately, we did not prospectively keep track of reasons for non-attendance at training hours in a systematic way. Most of our participants reported at three months as well as at the end of the study that the time and duration of training was satisfactory. Although we did not completely reach our goal of at least 40 training sessions for all participants who completed the study, we came close to it as the median number of sessions per person was 39 , while the average was 42 . However, this achievement was partly due to unexpected enthusiasm by some participants for additional training at the club facility. A second potential shortcoming of our study may be differences in training contents between the two training sites. However, sessions at our Taekwondo club site were also given by the projects' Taekwondo teachers, who took the aims of the study during such trainings into account. Therefore, program content between both sites did not differ much. A third point is that, considering the generally high education level of our participants, and the fact that most of them were already physically active in other ways, some caution is warranted when extrapolating our results to other types of middle-aged people.

In conclusion: Long-term Taekwondo training is feasible in healthy, middle-aged people. Participation is safe, is experienced as fun, and is subjectively beneficial for most. Age-adjusted Taekwondo should be listed among the sports from which middle-aged people can choose to increase their physical exercise. 


\section{References}

1. Rooks DS, Kiel DP, Parsons C, Hayes WC. Self-paced resistance training and walking exercise in community-dwelling older adults: effects on neuromotor performance. J Gerontol A Bio Med Sci 1997;52:161-8.

2. Lobstein T, Rigby N, Leach R. EU Platform on diet, physical activity and health 2005 . Aivailable from: http://eceuropaeu/health/ph_determinants/life_style/nutrition/documents/iotf_enpdf

3. Bucher DM, Cress ME, de Lateur BJ, Esselman PC, Margherita AJ, Price R, et al. A comparison of the effects of three types of endurance training on balance and other fall risk factors in older adults. Aging Clin Exp Res 1997;9:112-9.

4. Cress ME, Buchner DM, Questad KA, Esselman PC, deLateur BJ, Schwartz RS. Exercise : effects on physical functional performance in independent older adults. J Gerontol A Biol Sci Med Sci 1995;54:242-8.

5. Hain TC, Fuller L, Weil L, Kotsias J. Effects of Tai Chi on balance. Arch Otolaryngol Head Neck Surg 1999;125:1191-5.

6. Hausdorff JM, Rios DA, Edelberg HK. Gait variability and fall risk in community-living older adults: a 1-year prospective study. Arch Phys Med Rehabil 2001;82:1050-6.

7. Rubenstein LZ, Josephson KR. The epidemiology of falls and syncope. Clin Geriatr Med 2002;18:141-58.

8. Gabell ASM, Nayak US. Falls in the healthy elderly: predisposing causes. Ergonomics 1985;28:96575.

9. Hornbrook MC, Stevens VJ, Wingfield DJ, Hollis JF, Greenlick MR, Ory MG. Preventing falls among community-dwelling older persons: results from a randomized trial. Gerontologist 1994;34:16-23.

10. Tinetti ME, Speechley M, Ginter SF. Risk factors for falls among elderly persons living in the community. N Engl J Med 1988;319:1701-7.

11. Cromwell RL, Meyers PM, Meyers PE, Newton RA. Tae Kwon Do: an effective exercise for improving balance and walking ability in older adults. J Gerontol A Biol Sci Med Sci 2007;62:641-6.

12. Heller J, Peric T, Dlouhá R, Kohlíková E, Melichna J, Nováková H. Physiological profiles of male and female tae kwon-do (ITF) black belts. J Sports Sci 1998;16:243-9.

13. Hong Y, Li JX, Robinson PD. Balance control, flexibilty, and cardiorespiratory fitness among older Tai Chi practitioners. Br J Sports Med 2000;34:29-34. 
14. Imamura H, Yoshimura Y, Nishimura S, Nakazawa AT, Nishimura C, Shirota T. Oxygen uptake, heart rate and blood lactate responses during and following karate training. Med Sci Sports Exerc 1999;31:342-7.

15. Lan C, Lai JS, Wong MK, Yu ML. Cardiorespiratory function, flexibility, and body composition among geriatric Tai Chi Chuan practitioners. Arch Phys Med Rehabil 1996;77:612-6.

16. Lan C, Lai JS, Chen SY, Wong MK. 12-month Tai Chi training in the elderly: its effect on health fitness. Med Sci Sports Exerc 1998;30:345-51.

17. Lan C, Lai JS, Chen SY, Wong MK. Tai Chi Chuan to improve muscular strength and endurance in elderly individuals: a pilot study. Arch Phys Med Rehabil 2000;81:604-7.

18. Shaw DK, Deutsch DT. Heart rate and oxygen uptake response to performance of karate kata. J Sports Med Phys Fitness 1982;22:461-8.

19. Tse SK, Bailey DM. T'ai chi and postural control in the well elderly. Am J Occup Ther 1992;46:295300.

20. Wolf SL, Coogler C, Xu T. Exploring the basis for Tai Chi Chuan as a therapeutic exercise approach. Arch Phys Med Rehabil 1997;78:886-92.

21. Young DR, Appel $\amalg$, Jee S, Miller ER 3rd. The effects of aerobic exercise and T'ai Chi on blood pressure on older adults: results of a randomized trial. J Am Geriatr Soc 1999;47:277-84.

22. Zehr EP, Sale DG. Oxygen uptake, heart rate and blood lactate reponses to the Chito-ryu Seisan kata in skilled karate practitioners. Int J Sports Med 1993;14:269-74.

23. Zehr EP, Sale DG, Dowling JJ. Ballistic movement performance in karate athletes. Med Sci Sports Exerc 1997;29:1366-73.

24. Brudnak MA, Dundero D, Van Hecke FM. Are the 'hard' martial arts, such as the Korean martial art, TaeKwon-Do, of benefit to senior citizens? Med Hypotheses 2002;59:485-91.

25. Baratto L, Morasso PG, Re C, Spada G. A new look at posturographic analysis in the clinical context: sway-density versus other parameterization techniques. Motor Control 2002;6:246-70.

26. Csikszentmihalyi M. Flow: The Psychology of Optimal Experience. Harper Perennial Publications; 1991.

27. Philips LH. Sports injury incidence. Br J Sports Med 2000;34:133-6.

28. Lystad RP, Pollard H, Graham PL. Epidemiology of injuries in competition taekwondo: a metaanalysis of observational studies. J Sci Med Sport 2009;12:614-21. 
29 Hootman JM, Dick R, Agel J. Epidemiology of collegiate injuries for 15 sports: summary and recommendations for injury prevention initiatives. J Athl Train 2007;42:311-9. 


\section{Taekwondo training improves balance in volunteers over forty.}

G. Pons van Dijk, A.F. Lenssen, P. Leffers, H. Kingma and J. Lodder

Publication: Front Aging Neurosci. 2013 Mar 13;5:10. doi:10.3389/fnagi.2013. 00010. 


\section{Abstract}

Balance deteriorates with age, and may eventually lead to falling accidents which may threaten independent living. As Taekwondo contains various highly dynamic movement patterns, Taekwondo practice may sustain or improve balance. Therefore, in 24 middle-aged healthy volunteers (40-71 year) we investigated effects of age-adapted Taekwondo training of one hour a week during one year on various balance parameters, such as: motor orientation ability (primary outcome measure), postural and static balance test, single leg stance, one leg hop test, and a questionnaire.

Motor orientation ability significantly increased in favor of the antero-posterior direction with a difference of 0.62 degrees towards anterior compared to pre-training measurement, when participants corrected the tilted platform rather towards the posterior direction; female gender being an independent outcome predictor. On postural balance measurements sway path improved in all 19 participants, with a median of $9.3 \mathrm{~mm} / \mathrm{sec}$ (range 0.71-45.86), and sway area in 15 participants with $4.2 \mathrm{~mm}^{2} / \mathrm{sec}$ (range 17.39-1.22). Static balance improved with an average of 5.34 seconds for the right leg, and with almost 4 seconds for the left. Median single leg stance duration increased in 17 participants with 5 seconds (range 1-16), and in 13 participants with 8 seconds (range 1-18). The average one leg hop test distance increased (not statistically significant) with $9.5 \mathrm{~cm}$. The questionnaire reported a better 'ability to maintain balance' in sixteen.

In conclusion, our data suggest that age-adapted Taekwondo training improves various aspects of balance control in healthy people over the age of forty. 


\section{Introduction}

Maintenance of balance is a complex process, and depends on proper integration of various functional systems, such as the somatosensory, visual, vestibular and cerebellar system. Furthermore, it requires functional integrity of the peripheral neuromuscular system ${ }^{1}$. These various components deteriorate with age, and may eventually lead to falling accidents and threaten independent living. Vestibular function, for example, is severely reduced in over a third of people older than $65^{2}$. Consequences of balance deterioration are an important cause of morbidity among the elderly ${ }^{3}$. However, various types of physical activity and sports which particularly appeal to the proprioceptive system (Tai Chi, Yoga, dancing) have been shown to improve balance and to reduce the prevalence of falls in the elderly ${ }^{4-7}$. The effect of such activities on balance function is clearly better than that of those aimed to improve cardiovascular function (bioenergetic sports, like running) 8

The Korean martial art Taekwondo contains various jumping and weight shifting kicking exercises, which may resemble ballet and gymnastics. Because of these highly dynamic movement patterns, middle-aged or elderly may sustain the largest benefit with regard to dynamic locomotor components, including dynamic balance, from Taekwondo-based training. There are two studies in elderly people on the effects of Taekwondo training on a number of physical fitness components, including balance. Brudnak et al trained six senior subjects (63-81 yr) once a week during 17 weeks. They found an average increase of 16 seconds in the single-leg-stance test, which they used as a measure of balance. The authors concluded that Taekwondo training is possible in senior people, and that the profit they found would probably increase and last longer with longer training periods ${ }^{9}$. Cromwell et al. investigated 20 elderly (mean age $72.5 \mathrm{yr}$ ) who followed one-hour Taekwondo classes two times a week during 11 weeks. A number of parameters related to balance and walking pattern improved significantly in the Taekwondo group, but not in controls of the same age ${ }^{10}$. Although the results are interesting, program duration in these two studies was short, the number of subjects and the number of parameters studied small, and the number of dropouts unclear ${ }^{9,10}$. Therefore, in a group of healthy, elderly volunteers we studied the effect of one year Taekwondo training on several balance parameters, including motor orientation ability, postural balance, and physical tests for static and dynamic balance. If effective such Taekwondo-based exercise program could offer a cheap method to improve balance-dependent locomotor skills of the middle-aged and elderly, which eventually may contribute to the mitigation of the age-related loss of self-maintenance in the general population.

\section{Methods}

The study was a single arm intervention study in which participants served as their own control. 
Study population: Healthy male and female volunteers, 40-75 years of age. Inclusion criteria: Willingness to follow at least a one hour Taekwondo training session weekly. All volunteers had a routine neurological and cardiologic physical investigation and an exercise ECG. Exclusion criteria: Current psychiatric treatment, the use of oral anticoagulants and/or any disease that was expected to interfere with training, as judged by the volunteer's treating physician, the study neurologist (JL), or study cardiologist.

Recruitment and consent: Posters inviting people for participation were posted at various locations in the Maastricht Hospital and University buildings. Interested people were informed by oral and written information, and they were encouraged to follow at least two Taekwondo sessions at the trainers' Taekwondo club before enrolment.

Training sessions: Training intensity was adjusted to the participants' physical condition. The sessions lasted about one hour, and generally consisted of the following elements: a short warming-up; Taekwondo techniques, such as stances, blockings, kicks, punches, and strikes; poomsae (style figures), which are fixed patterns, illustrating a fight against one or more imaginary opponents; some elementary self-defense Taekwondo techniques. As Taekwondo combat sparring was considered injury prone, such practice was not included. We practiced the style of the World Taekwondo Federation, and in accord with the guidelines offered by the Kukkiwon, which is the official South Korean governmental Taekwondo governing organization ${ }^{11}$. We wrote each week's training program in advance as a training script, taking account of both the overall aims of the project and the volunteers' ability to cope with gradually increasing training intensity and complexity. Participants were advised to daily perform some simple balance exercises for five to ten minutes, and also to practice some simple stretching exercises. After each training session, we sent an e-mail letter to all participants with a reflection of the latest training session, a preview of the next one, and an invitation to make any comments on any aspect of the program.

The first training session took place on 21 October, 2009, and the final one on 19 January, 2011. We aimed at 40 lessons for each participant within one year, but because the attendance rate was lower than anticipated, we decided to extent the training period with three months. During the study, several participants chose to follow additional Taekwondo lessons at our Taekwondo club facility, where we adapted the club training program to comply with the study protocol. Number of lessons at the two locations was recorded separately.

Withdrawal: Subjects could leave the study at any time without any obligation to reveal their reasons, but we listed such reasons to evaluate the feasibility of the training program. We encouraged study participation by creating an informal atmosphere, and we reserved ample time for feedback.

Measurements: All participants were tested in the month before the start of the study, and as soon as possible after the last training session.

A questionnaire on the participants' subjective assessment on various aspects of the program was filled out three months after study onset, and at its end. 
Single leg stance test served to measure static balance ${ }^{12,13}$. While wearing shoes, subjects placed their weight bearing foot in a comfortable position on a three times folded $1 \mathrm{~cm}$ thick mat of flexible but solid imitation rubber. They were told to keep their eyes open, both hands on their hips, and their nonweight bearing limb in a slightly flexed position, as just not touching the floor. Three test trials were conducted for each leg separately. Duration (in seconds) measurement began when the subject lifted the non-weight bearing foot from the floor, and ended when the foot made contact with the floor.

One leg hop test served to measure dynamic balance, with distance in $\mathrm{cm}$ (first toe as reference point) as outcome parameter ${ }^{14,15}$. Subjects wore shoes and could freely move their arms, allowing a more functional execution of the hop ${ }^{16}$. Subjects were instructed to hop as far as possible, while taking off and landing on the same foot. The average of three hops served as final parameter.

Motor orientation ability was defined as the subjective proprioceptive horizontal - SPH as follows: subjects stood barefoot and blindfolded on a motor driven platform that was tilted at random over 110 degrees in 2D. Subsequently, by use of a joystick the subject had to adjust the platform orientation back to completely horizontal. The error-angle relative to the horizontal was then established in $2 \mathrm{D}$. The output parameters of the SPH was expressed as the mean with standard deviation of the error angle obtained after 10 trials in both antero-posterior (AP) and medio-lateral (LAT) direction. The relative change of mean AP and mean LAT, and the standard deviation (SDAP and SDLAT) of the error angle were used to express the motor orientation ability ${ }^{8,17}$.

Postural balance was tested by 40 second computerized measuring of the sway area, sway path and sway velocity (the latter is only used to calculate the other parameters), with subjects standing barefoot and blindfolded on an instable horizontal platform (stabulometry) with both feet pointing 20 degrees outward, and with both heels about $2 \mathrm{~cm}$ apart. Both sway path and sway area were used as balance parameters. The centre of pressure (COP) was sampled at $25 \mathrm{~Hz}, 16$ bits. Sway path was defined as the length of the trajectory of the COP divided by the measurement time $(\mathrm{mm} / \mathrm{sec})$. Sway area was defined as the time integral of the area swept by the COP trajectory with respect to the initial COP, divided by the measurement time $\left(\mathrm{mm}^{2} / \mathrm{sec}\right)^{18}$.

Static Balance: single limb stance test, which measures the time in seconds one could stand on one leg ${ }^{12,13}$. There was only one attempt for each leg, while subjects stood barefoot and blindfolded on a horizontal platform.

Two questionnaire items relevant to balance:

Since I started practicing Taekwondo training:

- my ability to maintain balance is:

- the 'elegance' with which I move is:

(answer options: much worse / worse / unchanged / better / much better). 
Statistics: Sample size estimation was based on the principle outcome parameter, which was the decrease in angle error on the Motor orientation ability test, using the following assumptions:

- The mean decrease over the study period would be approximately 0.24 degrees

- The inter-individual standard deviation of the decreases is 0.4 degrees (reflects the extent to which the participants will perform better)

- $\quad$ (one-sided) alfa $=0.05$

- power $=0.8$

For such difference to be detected, at least 17 subjects were required.

Data were analysed using SPSS, version 17.0, SPSS Inc., Chicago, IL. Baseline and final whole group data were compared using Wilcoxon Signed-Rank Test, expressed as average with standard deviation (SD), and paired T-test. Data of participants who improved or did worse are expressed as median with range. A p-value $<0.05$ was considered statistically significant.

\begin{tabular}{|c|c|c|c|c|}
\hline $\mathrm{Nr}$ & Gender & Age & $\begin{array}{c}\text { Education } \\
\text { level }\end{array}$ & $\begin{array}{c}\text { Physical } \\
\text { activity (hrs/wk) }\end{array}$ \\
\hline 1 & $\mathrm{~m}$ & 61 & $U$ & 15 \\
\hline 2 & $\mathrm{~m}$ & 61 & U & 10 \\
\hline 3 & $\mathrm{~m}$ & 62 & U & 0 \\
\hline 4 & $\mathrm{~m}$ & 59 & U & 7 \\
\hline 5 & $f$ & 41 & U & 0 \\
\hline 6 & $\mathrm{~m}$ & 58 & U & 9 \\
\hline 7 & $\mathrm{~m}$ & 51 & U & 4 \\
\hline 8 & $f$ & 49 & $\mathrm{H}$ & 3 \\
\hline 9 & $f$ & 60 & U & 10 \\
\hline 10 & $\mathrm{~m}$ & 66 & 0 & 10 \\
\hline 11 & $f$ & 50 & $\mathrm{H}$ & 5 \\
\hline 12 & $\mathrm{~m}$ & 57 & U & 4 \\
\hline 13 & $f$ & 51 & $\mathrm{H}$ & 3 \\
\hline 14 & f & 63 & U & 0 \\
\hline 15 & $\mathrm{~m}$ & 70 & U & 2 \\
\hline 16 & $\mathrm{~m}$ & 53 & U & 5 \\
\hline 17 & $f$ & 50 & $\mathrm{H}$ & 5 \\
\hline 18 & $\mathrm{~m}$ & 52 & $\mathrm{H}$ & 3 \\
\hline 19 & $f$ & 57 & $\mathrm{H}$ & 4 \\
\hline 20 & $\mathrm{~m}$ & 59 & $U$ & 0 \\
\hline 21 & $f$ & 60 & $U$ & 1 \\
\hline 22 & f & 44 & $\mathrm{H}$ & 10 \\
\hline 23 & $f$ & 51 & $\mathrm{H}$ & 1 \\
\hline 24 & $\mathrm{f}$ & 48 & $U$ & 0 \\
\hline
\end{tabular}

Table 1. Participants demograhics.

$\mathrm{U}=$ master degree or equivalent

$\mathrm{H}=$ bachelor degree or equivalent $\quad \mathrm{O}=$ other

Grey= non-complier 
Results

There were 12 men and 12 women; median age was 57 (range: 41-71) years. Table 1 shows individual demographic data. All participants had all baseline and final measurements, so there were no study dropouts. However, three women and two men withdrew early from the training program (noncompliers; participants' nr. 1, 14, 20, 22, 23). In two the reason was training-related, in two due to external reasons, and in the fifth a combination of both. The demographic characteristics of the noncompliers were similar to those of the subjects completing the study.

The one leg hop and single leg stance test were conducted in 17 participants. One participant missed the baseline test because he was abroad at that time. The other missed the final test due to a nontraining related shoulder injury. The other balance measurements were conducted in all 19 study compliers.

Results for baseline and final measures for all the participants are shown in Table 2.

\begin{tabular}{|c|c|c|c|c|c|}
\hline Measurement & Pre & SD & Post & SD & Significance \\
\hline \multicolumn{6}{|l|}{ Single leg stance (sec) } \\
\hline Right leg & 34.23 & 19.6 & 50.35 & 14.5 & 0.005 \\
\hline Left leg & 35.26 & 19.4 & 49.28 & 16.3 & 0.007 \\
\hline One leg hop (cm) & 100.74 & 27.4 & 110.23 & 39.61 & 0.28 \\
\hline \multicolumn{6}{|l|}{ Motor orientation ability $\left(^{\circ}\right)$} \\
\hline Anterio-posterior & 0.09 & 0.9 & -0.52 & 0.9 & 0.022 \\
\hline SD Anterio-posterior & 1.04 & 0.4 & 0.93 & 0.4 & 0.315 \\
\hline Lateral & 0.21 & 1.0 & 0.16 & 0.9 & 0.837 \\
\hline SD lateral & 0.78 & 0.3 & 0.60 & 0.3 & 0.064 \\
\hline \multicolumn{6}{|l|}{ Postural balance } \\
\hline Swaypath $(\mathrm{mm} / \mathrm{s})$ & 40.01 & 11.1 & 27.80 & 5.7 & 0.000 \\
\hline Swayarea $\left(\mathrm{mm}^{2} / \mathrm{s}\right)$ & 11.66 & 4.9 & 8.01 & 2.5 & 0.005 \\
\hline \multicolumn{6}{|l|}{ Static balance (sec) } \\
\hline Right leg & 5.22 & 4.6 & 10.56 & 6.6 & 0.004 \\
\hline Left leg & 5.53 & 3.8 & 9.50 & 6.0 & 0.039 \\
\hline
\end{tabular}

Mean

Table 2. Outcome measurements in study compliers

Pre= before Taekwondo training Post= after Taekwondo training SD= Standard deviation

Examination of balance measures shows significant improvement in several tests. Average time for single leg stance increased with 16.1 seconds for the right leg and 14.0 seconds for the left; both 
differences being statistically significant. Considering the right leg, 15 participants improved with a median of 22.8 seconds (range 5.3-52.0), and two deteriorated with 17.5 seconds (range 5.5-29.4), whereas there was a median improvement of 24 seconds in 15 participants (range 0.5-46), and a deterioration of 16.8 seconds (range 9.8-23.8) in two participants for the left leg stance.

The average one leg hop test distance increased (not statistically significant) with $9.5 \mathrm{~cm}$. Eleven participants had a median increased distance of $13.7 \mathrm{~cm}$ (range 1-70), whereas in six there was a median decrease of $18.7 \mathrm{~cm}$ (range 0.7-43.5).

Motor orientation ability significantly increased in favor of the antero-posterior direction with a difference of 0.62 degrees towards anterior compared to pre-training measurement, when the participants corrected the tilted platform rather towards the posterior direction. The error in adjusting the platform back to the horizontal (SD) did not change significantly neither in the anteriorposterior nor in the lateral direction. In total 15 participants improved with a median decrease of 0.7 degrees (range 2.55-0.14) and 4 participants did worse with a median increase of 0.53 degrees (range 0.36-0.99) in antero-posterior direction. In the lateral direction 10 participants improved with a median decrease of 0.7 degrees (range 2.97-0.7) and 9 participants did worse with an increase of 0.7 degrees (range 0.01-1.68).

On postural balance measurements, both sway path and sway area improved significantly as shown in table 1. Sway path improved in all 19 participants, with a median of $9.3 \mathrm{~mm} / \mathrm{sec}$ (range 0.71-45.86). Sway area improved in 15 participants with $4.2 \mathrm{~mm}^{2} / \mathrm{sec}$ (range 17.39-1.22) and increased in 4 participants with $1.7 \mathrm{~mm}^{2} / \mathrm{sec}$ (range 0.79-3.97).

Static balance improved with an average duration of standing on the right leg with 5.34 seconds, and with almost 4 seconds for the left leg, which were statistical significantly longer durations compared with pre-training measurements. Median right leg standing duration increased in 17 participants with 5 seconds (range 1-16), whereas it decreased in two participants with 6.5 seconds (range 1-12). Median left leg standing duration increased in 13 participants with 8 seconds (range 1-18), whereas it decreased in six participants with 3.5 seconds (range 2-6).

The questionnaire reported a better 'ability to maintain balance' in sixteen of the nineteen compliers, whereas it was unchanged in three. Three of the nineteen study compliers reported better 'elegance' of their movements, whereas 16 reported this item was unchanged. All non-compliers reported unchanged on both items.

To explore, whether age, gender, or the degree of non-study physical activity independently affected the differences we found, we used linear regression modeling with the primary outcome measure the Anterior-Posterior direction error angle of the Motor Orientation Ability Test as dependent variable, and as independent variables age, gender, and hours of non-study physical activity. Only gender appeared as independently affecting outcome $(p=0.043)$. When baseline AP measurements were added to the model, the baseline AP instead of gender appeared independently $(p=0.03)$ related to the increased AP forward correction. Exploring single leg stance outcome data yielded non-test physical 
activity independently inversely related for only the left leg $(p=0.034)$, and also only for the left leg in the static balance test $(p=0.050)$. Exploring sway path and sway area did not yield any of the independent variables to be associated with test outcome.

\section{Discussion}

Our data show that a one year weekly Taekwondo training improves various aspects of balance in middle-aged healthy people. Motor orientation ability was the primary endpoint measure we based our sample size estimation on, but the assumed improvement of a decrease in the angle in the direction of correction was not achieved. However, much to our surprise we observed a significant forward directed correction independent of the original direction of platform correction. None of the five non-compliers demonstrate a change in preferred direction of platform correction. Our data, therefore, suggest that Taekwondo training improves balance control by increased correction towards forward direction. Not only is leaning forward in an upright position more stable than leaning backwards, but our result concurs with the 'optimal bending' model presented in Alexandrov et al, in which forward bending is taken as an anticipatory postural adjustment ${ }^{19,20}$.

Increased loss of balance in the elderly may relate to an age-related increase of posterior sway at the expense of a decrease of forward sway which is much more effective in balance maintenance. Younger people use the forefoot's muscle activity for maintenance of balance more intensely than elderly, who rather tend to use heel area function in the posterior sway. As the maximal range of forward sway to maintain balance is twice as large as in backward sway (eight versus four degrees), elderly are more prone to fall, and when they do it is often backwards ${ }^{21}$. This shift towards more intensive use of forward control in balance control after Taekwondo training likely results from the typical stances, movement in such stances, and the footwork in Taekwondo exercises, as these movements require the center of gravity to be balanced by mainly forefoot function ${ }^{22}$.

From our findings we may hypothesize that age-adapted Taekwondo training may contribute to lowering the chance of falls in the elderly. Even if in case of an imposed disequilibrium trained subjects may not be able to correct this completely, they may fall forward rather than backward, which may be less hazardous than falling backwards ${ }^{23}$.

Although our study was not powered to any a priori hypothesis on a differential effect between men and women, post-hoc exploration by means of linear regression analysis suggested that especially women may benefit from the training, as female gender emerged as independently related to the outcome measure. This finding may relate to a lower initial forward correction in females than in males. In fact, the average initial correction was 0.62 degrees backwards in women, which improved to 0.35 forwards (difference: 0.97 ), whereas men increased their initial average forward correction of 0.37 to 0.68 (difference: 0.31 ). One may speculate about the cause of these differences, but we should realize that these are post-hoc findings in a small group. In any case our findings stress the importance of accounting for the possibility of substantial differences between balance 
performances based on gender, and future studies should be sufficiently powered to account for such difference.

Sway path and sway area both decreased significantly, which was probably related to the fact the center of gravity had moved forwards, with a higher plantar pressure providing stronger sensory stimulation to the mechanoreceptors. This effect would result in an overall increased neural feedback from the cutaneous receptors to the central nervous system, and possibly contribute to improved postural control ${ }^{24}$. Subjective judgment by our volunteers on balance control was in line with measurement data. Linear regression did not detect any independently related outcome predictors for sway path and sway area.

Another way we measured balance and which had improved after training was the single leg stance, both with eyes open and closed. Dependence upon visual information for balance maintenance increases with age ${ }^{25}$. Our data suggest that Taekwondo training improves postural control by improving vestibular or proprioceptive input, or both, as participants were less dependent on visual information at the end of the study. These data may implicate that during walking single leg support is prolonged and the duration of double leg support shortened. Such dynamic locomotor components decrease with age: steps become shorter, walking pace decreases, the time that both feet touch the ground during walking increases (double support) ${ }^{5,6,26-28}$. Therefore, Taekwondo training may improve stable walking with a decrease in the chance of falling accidents when people get older. However, this remains hypothetical as we did record neither the duration of single or double leg support during walking nor the frequency of falling accidents in our volunteers. The only factor that came out as independently associated in both leg standing performance tests, but only for the left leg, was the number of hours of non-study physical activity, in this sense that a lower physical activity was associated with more improvement. This finding may suggest that the non-dominant leg may become more involved in static balance maintenance by Taekwondo training in physically nonactive people but that such improvement may not be specific for Taekwondo.

The one leg hop test showed a (statistically non-significant) mean distance increase of $9.02 \mathrm{~cm}$. It should be reminded that this test was developed for measurements in patients with anterior cruciate ligament reconstruction ${ }^{29}$. Because apart from joint stability it encompasses clinical attributes such as neuromuscular coordination and proprioception we used it to test (dynamic) balance. However, the test has not been validated for balance, and may not serve as a dynamic balance measure.

The effects of the training program on balance control could not be related to an increase of leg muscle power as measured with a Biodex System 3 Pro dynamometer. We found no increase in either isometric or isokinetic measurement data of quadriceps or hamstring muscles, which suggests that changes rather took place at neural or vestibular level.

Beneficial effects of training on balance control may not be specific for Taekwondo, as other martial arts or even mere physical activity may have such effects ${ }^{30}$. One of the martial arts that has been 
studied frequently and had positive effects on balance is Tai $\mathrm{Chi}^{31}$, although the desired practical implications such as a lower risk of fall accidents do not simply seem to follow from such effects ${ }^{32}$. However, any direct comparison of studies remains difficult because of differences in various aspects of study design and outcome parameters. Taekwondo differs especially from Tai Chi regarding movement dynamics, and eventually elderly who are able to perform more dynamic movement patterns may opt for age-adjusted Taekwondo or otherwise choose for Tai Chi.

Our study suffers some limitations. First, it was not randomized. Although theoretically unknown factors might have contributed to the improvements that we found, we consider this unlikely as we would not expect parameters to improve with a year of further aging. Therefore, we think it unlikely to have measured random noise. Second, considering the generally high education level of our participants, and the fact that most of them were already physically active in other ways, some caution is warranted when extrapolating our results to middle-aged people in general ${ }^{33}$. Third, there were five non-compliers, but we were still able to conclude the study with more participants than the sample size estimation required.

In conclusion, our data suggest that age-adapted Taekwondo training improves various aspects of balance control in healthy people over the age of forty. Recently we reported on the feasibility and safety of such training program ${ }^{33}$. Whether long-term adherence to age-adapted Taekwondo training indeed has a beneficial effect on mobility and fall accident frequency in people with a higher age remains for further study. 


\section{References}

1. Nasher, L. (1997). Practical biomechanics and physiology of balance. Jacobson G, Newman CW, Kartush JM (eds) Handbook of balance function testing. Singular Publishing Group, San Diego, 261-279.

2. Ishiyama, G. (2009). Imbalance and Vertigo: The Aging Human Vestibular Periphery. Semin Neurol 29, 491-499.

3. Wolter LL, Studenski SA. (1996). A clinical synthesis of falls intervention trials. Top. Geriatr. Rehabil. 11, 9-19.

4. Aydin T, Yildiz Y, Yildiz C, Atesalp S, Kalyon TA. (2002). Proprioception of the ankle: a comparison between female teenaged gymnasts and controls. Foot Ankle Int. 23, 123-129.

5. Hausdorff JM, Rios DA, Edelber HK. (2001). Gait variability and fall risk in community-living older adults: a 1-year prospective study. . Arch Phys Med Rehabil. 82, 1050-1056.

6. Rubenstein LZ, Josephson K. (2002). The epidemiology of falls and syncope. Clin Geriatr Med. $18,141-158$.

7. Simmons, R. (2005). Sensory organization determinants of postural stability in trained ballet dancers. Int J Neurosci. 115, 87-97.

8. Gauchard GC, Gangloff P, Jeandel C, Perrin PP. (2003). Influence of regular proprioceptive and bioenergetic physical activities on balance control in elderly women. J Gerontol A Biol Sci Med Sci. 58, 846-850.

9. Brudnak MA, Dundero D, Van Hecke FM (2002). Are the 'hard' martial arts, such as the Korean martial art, TaeKwon-Do, of benefit to senior citizens? Med Hypotheses. 59, 485-491.

10. Cromwell RL, Meyers PM, Meyers PE, Newton RA. (2007). Taekwondo: An effective exercise for improving balance and walking ability in older adults J of Gerontol: Medical Sciences. 62A, 641-646.

11. http://www.wtf.org/.

12. Hong Y, Li XJ, Robinson PD. (2000). Balance control, flexibilty, and cardiorespiratory fitness among older tai chi practitioners. Br J Sports Med 34, 24-29.

13. Rikli RE, Edwards DJ. (1991). Effects of a three-year exercise program on motor function and cognitive processing speed in older women. Res Q Exerc Sport 62, 61-67.

14. Ageberg E, Thomeé R, Neeter C, Silbernagel KG, Roos EM. (2008). Muscle strength and functional performance in patients with anterior cruciate ligament injury treated with training and surgical reconstruction or training only: a two to five-year followup. Arthritis Rheum 59, 1773-1779.

15. Augustsson J, Thomeé R, Karlsson J. (2004). Ability of a new hop test to determine functional deficits after anterior cruciate ligament reconstruction. Knee Surg Sports Traumatol Arthrosc. $12,350-356$. 
16. Ageberg E, Zätterström R, Fridén T, Moritz U. (2001). Individual factors affecting stabilometry and one-leg hop test in 75 healthy subjects, aged 15-44 years. Scand I Med Sci Sports 11, 4753.

17. Gauchard GC, Jeandel C., Tessier A, Perrin PP. (1999). Beneficial effect of proprioceptive physical activities on balance control in elderly human subjects. Neurosci Lett. 273, 81-84.

18. Baratto L, Morasso PG., Re C, Spada G (2002). A new look at posturographic analysis in the clinical context: Sway-density versus other parameterization techniques. Motor Control 6, 246-270.

19. Massion, J. (1992). Movement, posture and equilibrium: interaction and coordination. Prog Neurobiol. . 38, 35-65.

20. Alexandrov A, Frolov AA, Massion J. (2001). Biomechanical analysis of movement strategies in human forward trunk bending. II. Experimental study. Biol Cybern. 84, 435-443.

21. Tanaka T, Takeda H., Izumi T, Ino S, Ifukube T. (1999). Effects on the location of the centre of gravity and the foot pressure contribution to standing balance associated with ageing. Ergonomics. 42, 997-1010.

22. Leong HT, Fu SN, Ng GY, Tsang WW. (2011). Low-level Taekwondo practitioners have better somatosensory organisation in standing balance than sedentary people. Eur J Appl Physiol. $111,1787-1793$.

23. Choi CJ, Lim HW, Park MK, Cho JG, Im GJ, Chae SW. (2011). Does the kyphotic change decrease the risk of fall? Clin Exp Otorhinolaryngol. 4, 118-121.

24. Qiu F, Cole MH, Davids KW, Hennig EM, Silburn PA, Netscher H, Kerr GK. (2012). Enhanced somatosensory information decreases postural sway in older people. Gait Posture.

25. Gauchard GC, Jeandel C, Perrin PP. (2001). Physical and sporting activities improve vestibular afferent usage and balance in elderly human subjects. Gerontology. 47, 263-270.

26. Gabell A, Simons MA, Nayak US. (1985). Falls in the healthy elderly: predisposing causes. . Ergonomics. 28, 965-975.

27. Hornbrook MC, StevensVJ, Wingfield DJ, Hollis JF, Greenlick MR, Ory MG. (1994). Preventing falls among community-dwelling older persons: results from a randomized trial. Gerontologist. 34, 16-23.

28. Tinetti ME, Speechley M., Ginter SF. (1988). Risk factors for falls among elderly persons living in the community. N Engl J Med. 319, 1701-1707.

29. Tegner $Y$, Lysholm J., Lysholm M, Gillquist J. (1986). A performance test to monitor rehabilitation and evaluate anterior cruciate ligament injuries. Am J Sports Med. 14, 156-159.

30. Perrin PP, Gauchard GC, Perrot C, Jeandel C (1999). Effects of physical and sporting activities on balance control in elderly people. Br J Sports Med. 33, 21-126.

31. Maciaszek J, Osiński W. (2010). The effects of Tai Chi on body balance in elderly people--a review of studies from the early 21st century. Am J Chin Med. 38, 219-229.

32. Logghe IH, Zeeuwe E., Verhagen AP, Wijnen-Sponselee RM, Willemsen SP, Bierma-Zeinstra SM, Van Rossum E, Faber MJ, Koes BW. (2009). Lack of effect of Tai Chi Chuan in preventing falls in elderly people living at home: a randomized clinical trial. J Am Geriatr Soc. 57, 70-75. 
33. Pons van Dijk G, Leffers P, Lodder J. Feasibility, safety and subjective experience of a oneyear WTF-Taekwondo training course for middle-aged volunteers; the Sekwondo study. Gazz Med Ital-Arch Sci Med 2013. 172(6): p. 433-441. 


\section{4}

\section{Cognition improvement in Taekwondo novices over forty. Results from the SEKWONDO Study.}

G. Pons van Dijk, M. Huijts and J. Lodder.

Published: Front Aging Neurosci. 2013 Nov 11;5:74. doi: 10.3389/fnagi.2013.00074. eCollection 2013. 


\section{Abstract}

Age-related cognitive decline is associated with increased risk of disability, dementia and death. Recent studies suggest improvement in cognitive speed, attention and executive functioning with physical activity. However, whether such improvements are activity specific is unclear.

Therefore, we aimed to study the effect of one year age-adapted Taekwondo training on several cognitive functions, including reaction/ motor time, information processing speed, and working and executive memory, in 24 healthy volunteers over forty.

Reaction and motor time decreased with 41.2 seconds and 18.4 seconds $(p=0.004, p=0.015)$, respectively. Digit symbol coding task improved with a mean of 3.7 digits $(p=0.017)$. Digit span, letter fluency, and trail making test task-completion-time all improved, but not statistically significant. The questionnaire reported "better" reaction time in 10 and "unchanged" in 9 of the nineteen study compliers.

In conclusion, our data suggest that age-adapted Taekwondo training improves various aspects of cognitive function in people over 40 , which may, therefore, offer a cheap, safe and enjoyable way to mitigate age-related cognitive decline. 


\section{Introduction}

Age-related cognitive decline is associated with increased risk of disability, dementia and death. Especially in Western societies this problem is expected to increase in the coming decades, underscoring the need for strategies to reduce the chance of cognitive decline ${ }^{1}$. Recent studies suggest improvements on cognitive speed, auditory and visual attention ${ }^{2}$, and executive functioning

${ }^{3}$ by increasing physical activity. The cardiovascular fitness hypothesis of McAuley et al. proposes that the effect of physical activity on cognitive function is mediated by two mechanisms: 1) disease reduction (e.g. stroke, diabetes, hypertension and cardiovascular disease), and 2) enhancement in brain structure and function (e.g. increased production and efficiency of neurotransmitters, angiogenesis, synaptogenesis, and neurogenesis) ${ }^{4}$. Changes in aerobic fitness are thus suggested to precede changes in cognitive function ${ }^{2}$. Contemporary dance ${ }^{5}$ and bio-energetic sports ${ }^{2-4}$ have been shown to improve several aspects of cognition in the elderly. Practicing Tai Chi ${ }^{6-8}$, a 'soft' martial art, had similar effects. We recently showed that age-adapted Taekwondo training is feasible, safe and fun, whereas it improved the overall feeling of wellbeing ${ }^{9}$. Since Taekwondo training improves aerobic performance capacity, it could also improve cognitive function, or at least mitigate agerelated cognitive decline ${ }^{10}$. In the absence of any study so far, we aimed to study the effect of one year Taekwondo training on several cognitive functions, including reaction and motor time, information processing speed, and working and executive semantic memory, in a group of healthy, volunteers over forty. If effective, such Taekwondo-based exercise program could offer a cheap method to lower age-related cognitive decline, which eventually might contribute to mitigate agerelated loss of self-maintenance in the general population.

\section{Methods}

Study methods as to participant recruitment, sample size estimation, and intervention were described in detail elsewhere ${ }^{11}$. We listed only those items relevant to the present study. For the study protocol description, see the internet link below. The study was designed as a single arm intervention study in which 24 participants served as their own control.

Study population: Twelve male and twelve female volunteers between 41 and 71 years of age, see Table 1.

Inclusion criteria: Willingness to follow at least a one hour Taekwondo training session weekly. All volunteers had a routine neurological and cardiologic physical investigation and an exercise ECG.

Exclusion criteria: Current psychiatric treatment, the use of oral anticoagulants or any disease that was expected to interfere with training, as judged by the volunteer's treating physician, the study neurologist (JL), or study cardiologist. 


\begin{tabular}{lcccc}
\hline $\mathbf{N r}$ & Gender & Age & $\begin{array}{c}\text { Education } \\
\text { level }\end{array}$ & $\begin{array}{c}\text { Physical } \\
\text { activity (hrs/wk) }\end{array}$ \\
\hline 1 & $\mathrm{~m}$ & 61 & $\mathrm{U}$ & 15 \\
2 & $\mathrm{~m}$ & 61 & $\mathrm{U}$ & 10 \\
3 & $\mathrm{~m}$ & 62 & $\mathrm{U}$ & 0 \\
4 & $\mathrm{~m}$ & 59 & $\mathrm{U}$ & 7 \\
5 & $\mathrm{f}$ & 41 & $\mathrm{U}$ & 0 \\
6 & $\mathrm{~m}$ & 58 & $\mathrm{U}$ & 9 \\
7 & $\mathrm{~m}$ & 51 & $\mathrm{U}$ & 4 \\
8 & $\mathrm{f}$ & 49 & $\mathrm{H}$ & 3 \\
9 & $\mathrm{f}$ & 60 & $\mathrm{U}$ & 10 \\
10 & $\mathrm{~m}$ & 66 & $\mathrm{O}$ & 10 \\
11 & $\mathrm{f}$ & 50 & $\mathrm{H}$ & 5 \\
12 & $\mathrm{~m}$ & 57 & $\mathrm{U}$ & 4 \\
13 & $\mathrm{f}$ & 51 & $\mathrm{H}$ & 3 \\
14 & $\mathrm{f}$ & 63 & $\mathrm{U}$ & 0 \\
15 & $\mathrm{~m}$ & 70 & $\mathrm{U}$ & 2 \\
16 & $\mathrm{~m}$ & 53 & $\mathrm{U}$ & 5 \\
17 & $\mathrm{f}$ & 50 & $\mathrm{H}$ & 5 \\
18 & $\mathrm{~m}$ & 52 & $\mathrm{H}$ & 3 \\
19 & $\mathrm{f}$ & 57 & $\mathrm{H}$ & 4 \\
20 & $\mathrm{~m}$ & 59 & $\mathrm{U}$ & 0 \\
21 & $\mathrm{f}$ & 60 & $\mathrm{U}$ & 1 \\
22 & $\mathrm{f}$ & 44 & $\mathrm{H}$ & 10 \\
23 & $\mathrm{f}$ & 51 & $\mathrm{H}$ & 1 \\
24 & $\mathrm{f}$ & 48 & $\mathrm{U}$ & 0 \\
\hline & & & & \\
\hline
\end{tabular}

Table 1. Participants demograhics.

$\mathrm{U}=$ master degree or equivalent $\quad \mathrm{H}=$ bachelor degree or equivalent $\quad \mathrm{O}=$ other

Grey= non-complier

Recruitment: Posters inviting people for participation were posted at various locations in the Maastricht University Medical Center and the Maastricht University. People interested in the study were informed by oral and written information, and they were encouraged to follow at least two Taekwondo sessions at the trainers' Taekwondo club before enrolment.

Ethical consideration. The study was conducted according to the principles of the Declaration of Helsinki, and in accordance with the Dutch Medical Research Involving Human Subjects Act (WMO). It was approved by the Maastricht University Medical Center Ethical Committee and listed before study onset in the linked, Dutch Trial Registry: www.trialregister.nl/trialreg/admin/rctsearch.asp under the acronym "SEKWONDO Study". Informed consent was provided and signed before initiation of the study. 


\section{Intervention}

The weekly training sessions lasted about one hour. Training intensity was adjusted to the participants' physical condition, and adapted over time. Training sessions started on 21 October, 2009, and ended on 19 January, 2011. We aimed at 40 lessons for each participant in one year, but since attendance rate was lower than anticipated, we decided to extend the training period with three months to a total of 15 months. The training sessions lasted one hour, and generally consisted of the following elements: a warming-up with muscle strengthening and light stretching exercises; Taekwondo techniques, such as style figures (poomsae), which are fixed patterns illustrating a fight against one or more imaginary opponents; stances, blockings, kicks and punches, which were trained as basic exercises, with kicking pads, or facing an opponent. A small number of elementary self-defence techniques based on Taekwondo elements were also included. Training sessions ended with a cooling-down, including stretching exercises ${ }^{12,13}$. To prevent possible injuries, Taekwondo combat sparring was not practiced. For more details see Pons van Dijk et al. ${ }^{9,11}$.

\section{Measurements}

All participants were tested one month before the start of the study, and in the month after the last training session.

Reaction test: This test consists of two parts. In the first part participants are asked to hold their index finger on a golden button. As soon as a yellow light appears on the screen they should press a black button as quickly as possible, and then return to the golden button as quickly as possible. In the second part, participants are asked only to respond (by pressing the black button) when the yellow light appears on the screen together with hearing a tone. Other conditions like a red light or a yellow light with no tone were "no go's", and participants should withhold their response. This task measures reaction time and motor speed. Reaction time (RT) is the time from signal to the moment of releasing the golden button. The motor time (MT) is the time from releasing the golden button to pressing the black button ${ }^{14}$. The numbers 1 and 2 refer to the part for which the RT and MT were measured.

Digit Symbol Coding (Wechsler adult intelligence scale fourth edition, (WAIS-IV)): This test is based on the substitution of numbers into symbols according to an explicit code. It provides information on motor speed, information processing speed and visuo-motor coordination. The raw score corresponds to the number of symbols substituted correctly within 120 seconds ${ }^{15}$.

Digit Span (WAIS-IV): A series of numbers, starting with three consecutive numbers and a maximum of eight consecutive numbers, is being read to the participant. In the first subtask (forward), the participant is asked to repeat the number series. In the second subtask (backward), the participant is asked to repeat the numbers, but in reverse order. This test assesses short memory and working memory, respectively ${ }^{15}$. 
Letter Fluency: Participants are asked to name as many words as possible starting with a certain letter within a certain time frame. This task provides information on the ability to retrieve semantic memory items in a strategic way ${ }^{16}$.

Trailmaking Test $A$ and $B$ : In the first subtask (card A), the numbers 1 to 13 are placed in random order on a sheet of paper, and participants are asked to connect the numbers in ascending order as fast as possible. In the second subtask (card B) numbers and letters are placed in random order, which have to be connected alternately in ascending and alphabetical order. An interference score was computed as time on card B minus time card A. This task provides information on the ability to concentrate, set-shifting, visual perception/attention, working memory and the ability to concentrate 17 .

Questionnaire: A questionnaire on the participants' subjective assessment on various aspects of the program was conducted at the end of the training period. There were two questions relevant to cognitive function:

Since I started practicing Taekwondo training:

My mental fitness is:

My reaction time is:

(answer options: much worse / worse / unchanged / better / much better).

Statistical analysis

Data were analysed using SPSS, version 17.0, SPSS Inc., Chicago, IL. Baseline and final group data were compared using non-parametric Wilcoxon Signed-Rank Test and paired T-test, expressed as mean with standard deviation (SD). A p-value $<0.05$ was considered statistically significant.

\section{Results}

Median participants' age was 57 (range: 41-71) years. All participants had baseline and final measurements, so there were no study dropouts. However, three women and two men withdrew early from the training program (non-compliers). Demographic characteristics of the non-compliers did not differ from those of study compliers (Table 1 ).

Results of pretest and posttest measurements for the 19 compliers are shown in Table 2 and Figure 1.

The reaction test: reaction and motor time measured in the first task decreased (non-significantly) with 2.5 seconds and 4.9 seconds, respectively. Reaction and motor time in the second sub-task decreased with 41.2 seconds and 18.4 seconds, respectively; both differences being statistically significantly. Nine participants showed lower values (median 36 seconds, range 5-96) in RT1, and 16 participants (median 45 seconds, range 9-180) in RT2. Ten participants had higher RT1 values (median 21 seconds, range 5- 
53), and three higher RT2 values (median 59 seconds, range 3-71). The MT1 decreased in 12 participants with a median of 22 seconds (range 3-48), and MT2 in 13 with a median of 18 seconds (range 4-115). Seven participants had higher MT1 values (median 19 seconds, range 9-36), and seven higher MT2 values (median 7.5 seconds, range 1-22).

\begin{tabular}{rccccc}
\hline Measurement & Pre & SD & Post & SD & Significance \\
\hline Reaction time (s) & & & & & \\
Light & 310.0 & 55.7 & 307.4 & 50.1 & 0.784 \\
Light and sound & 502.5 & 95.1 & 461.4 & 76.2 & 0.004 \\
Motor time (s) & & & & & \\
Light & 161.9 & 58.8 & 157.0 & 58.0 & 0.359 \\
Light and sound & 168.1 & 74.3 & 149.7 & 58.6 & 0.015 \\
Digit symbol coding (\#) & 74.2 & 10.8 & 77.8 & 12.6 & 0.017 \\
Digit Span (\#) & & & & & \\
Forward & 8.79 & 1.75 & 9.42 & 1.80 & 0.083 \\
Backward & 6.53 & 1.74 & 6.84 & 1.38 & 0.542 \\
$\quad$ Total & 15.37 & 3.02 & 16.26 & 2.92 & 0.120 \\
Letter fluency (\#) & 44.47 & 10.7 & 47.42 & 10.5 & 0.064 \\
Trail making (s) & & & & & \\
Numbers & 28.42 & 10.1 & 28.26 & 9.07 & 0.939 \\
Letters & 62.89 & 20.0 & 59.26 & 15.7 & 0.143 \\
Difference & 34.47 & 15.0 & 31.00 & 13.5 & 0.304 \\
\hline
\end{tabular}

Mean , \# is number

Table 2 Outcome measurements compliers

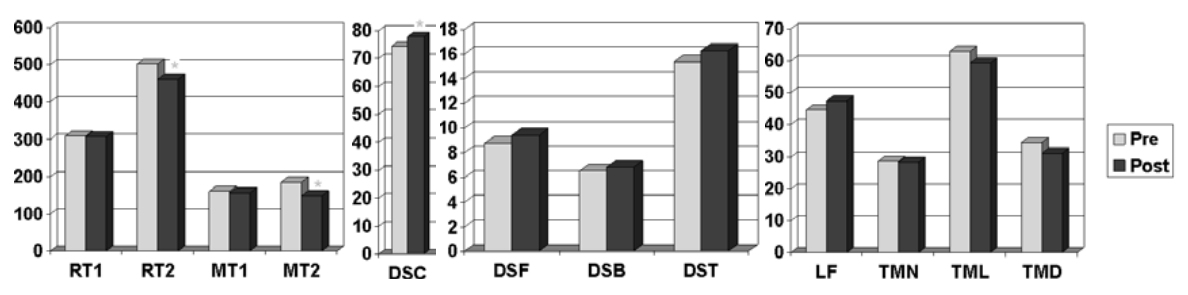

Figure 1. Outcome measurements compliers

$* p<0.05$

RT1: reaction time light RT2: reaction time light and sound MT1: motor time light MT2: motor time light and sound DSC: digit symbol coding DSF: digit span forward

DSB: digit span backwards DST: digit span total LF: letter fluency TMN: trail making numbers TML: trail making letters TMD: trail making difference 
The digit symbol coding task values decreased significantly with a mean of 3.7 digits $(p=0.017)$. Fourteen participants had lower values with a median of 6 digits (range 1-14), and 5 participants had higher values with a median of 4 digits (range 3-5).

The digit span increased, forwards with 0.6 digits, backwards with 0.3 digits, and the total digit span increased with 0.9 digits; these changes were not statistically significant. An increase of digit span was seen in nine participants with a median of 1 digit (range 0-3), eight participants did not change, whereas two participants had lower values with a median of 1.5 digits (range 1-2) in the digit span forward. In the backwards digit span eight participants had higher values with a median of 1.5 digits (range 0-3), seven participants showed no change, whereas four participants had lower values with a median of 2 digits (range 1-4). Sixteen participants showed higher values with a median of 2 digits (range 1-4), and three had lower values with a median of 2 digits (range 1-4).

The letter fluency test; overall there was a mean increase of 3 letters $(p=0.06)$. Fourteen participants showed an increase with a median of 8 letters (range 1-14), and five participants a decrease with a median of 6 letters (range 2-13).

The trail making test: the task-completion-time decreased in the first part with a mean of 0.16 seconds, the second part with 3.6 seconds, whereas the difference decreased (not statistically significant) with 3.5 seconds. The first part showed a decrease in nine participants with a median of 6 seconds (range 120), whereas ten participants showed an increase with a median of 4 seconds (range 1-20). The second part showed a decrease in 14 participants with a median of 16.5 seconds (range 2-28), and an increase in 5 participants with a median of 18 seconds (range 9-31). Regarding the difference between the two tasks, 11 participants decreased with a median of 11 seconds (range 6-48), while 8 participants increased with 9.5 seconds (range 1-34).

The questionnaire: five of the nineteen compliers reported "better" mental fitness, whereas fourteen reported "unchanged". Ten of the nineteen study compliers reported "better" reaction time, whereas 9 reported this item as "unchanged". All non-compliers reported "unchanged" on both items.

\section{Discussion}

Our study showed that a weekly one-hour Taekwondo training for the duration of 15 months improves several aspects of cognition in participants over forty, in particular cognitive speed relating to inhibition improved, as well as in information processing.

One part of Taekwondo is sparring, in which apart from tactics, speed and technique are important elements. We included various sparring-related techniques in our program (although never with actual physical contact) which focused on acquiring controlled motor speed and reflex motor reaction time, as well as timely inhibition of movements ${ }^{18}$. Other training aspects which involve reaction time and 
inhibition were punching and kicking exercises using pads, in which one has to master motor control and motor speed. Such exercises may also stimulate visuo-motor coordination.

We found no other studies on the effects of Taekwondo on cognitive functions in people over 40 . One recent study in 15 male participants practicing karate, a hard martial arts resembling Taekwondo, found no improvement in RT1 reaction time ${ }^{19,20}$.

Recent studies on aerobic exercise, like swimming and running, showed improvements in cognitive functioning in elderly people ${ }^{3,21}$. However, many community-dwelling elderly do not exercise because of little physical strength and multiple medical conditions ${ }^{22}$. Therefore, exercises should be adapted to their physical condition, like our program of age-adapted Taekwondo ${ }^{9}$. A relationship between training intensity and degree of results by physical exercise is highly plausible. However, the difficulty is that training intensity is hard to define as opposed to training frequency or duration when it concerns complex movement patterns as opposed to the training of less complex character, such as running e.g.. However, the characterization of the movement complexity may well reflect the degree of training intensity to eventually master them. We cannot describe the complexity of Taekwondo poomsae execution, but this may be appreciated by observing such execution at for example: www.wtf.org ${ }^{12}$.

As mentioned above we also found an improvement in information processing, combined with motor speed and visuo-motor coordination. Especially processing speed is one of the cognition components which deteriorates with age ${ }^{23,24}$ and is demanded in more complex tasks during daily activities, such as for example walking and talking at the same time. The other components on which our participants improved, mainly consist of tasks related to working memory and executive functions.

The improvements we found did not relate to improvement of cardiac function (exercise ECG data not reported here), which suggests that exercise-related improvement of cognitive functions do not solely depend on cardio-aerobic improvement. We suspect that cognitive improvement in our study resulted from the training of rather complex motor patterns which are inherent to Taekwondo, especially during style or poomsae training. The participants practiced three different poomsaes, which demanded memory training for complex motor sequences, as well as mental concentration and attention. Poomsae performance resembles Tai Chi, with the difference that poomsae training is much more dynamic in terms of alteration of initiation, performance, and inhibition of complex movement patters. Several studies demonstrated improved cognitive function by Tai Chi practice ${ }^{25,26}$. Because of the more dynamic character of Taekwondo reaction and motor time, as well as working memory and information processing speed may be stimulated even more than by Tai Chi training, although this cannot be established with certainty without direct comparing both arts.

Our study has limitations, one of which is the absence of a control group. However, as we did not expect performances to improve with another year of ageing, participants functioned as their own controls. One may question the specificity of the intervention on study outcome parameters, as most participants were also physically active in other ways. However, first of all other activities included also mild exercising such as walking, whereas we aimed to indicate that our population was not 
completely sedentary. Furthermore, we considered the Taekwondo training as the intervention on top of the participants' habitual activities, and considered responsible for the effects we found. However, without a strict controlled design we cannot be fully certain of the intervention's specificity. Another limitation concerns extrapolating our results to people over forty in general, since our sample was rather small, whereas our participants were on average highly educated. The early withdrawal of five participants could be regarded as a study drawback, but these five still completed follow-up measurements, and are 'non-compliers' and not study dropouts. Moreover, based on our sample size estimation for the primary outcome measure, which was a balance parameter, eventual complete study adherence in 17 would suffice.

Due to an increase of the number of elderly people, cognitive impairment is becoming a major societal problem. There are still few, if any, solutions to this problem. Pharmaco-therapeutical possibilities are just emerging but so far had only minor impact on a population level, whereas as it offers no certainty for any improvement on an individual level ${ }^{27,28}$. Other options, for instance day care and other entertaining programs put high demands on money and personal. Our results suggest that Taekwondo- based exercises may offer a way to mitigate age-related cognitive decline, which, moreover, is cheap, safe and enjoyable ${ }^{9}$.

In perspective, our results show that practicing Taekwondo improves various aspects of cognitive function in people over 40 . Earlier we found that such practice is cheap, safe, and enjoyable ${ }^{9}$ whereas it also improves balance maintenance ${ }^{11}$. The practice does not require exhaustive training intensity to achieve results. Considering the already available training infra-structure by means of the wide spread presence of Taekwondo clubs in many countries worldwide, from the perspective of health improvement on a societal level governmental policy may already be directed towards offering this training possibility to the general public. However, more studies on the effects of Taekwondo on cognitive function in the elderly are required to make specific recommendations as to when to begin such training and with what degree of intensity it should be practiced for optimal results. Besides, Taekwondo organizations and their trainers should be made aware of this new and important possibility Taekwondo has to offer. 


\section{References}

1. Alzheimer's Association. 2009 Alzheimer's disease facts and figures. Alzheimers Dement (2009) 5(3):234-70.

2. Angevaren M, Aufdemkampe G, Verhaar HJ, Aleman A, Vanhees L. Physical activity and enhanced fitness to improve cognitive function in older people without known cognitive impairment. Cochrane Database Syst Rev (2008) 16(3):CD005381. Review.

3. Colcombe S, Kramer AF. Fitness effects on the cognitive function of older adults: a metaanalytic study. Psychol Sci (2003) 14:125-30.

4. McAuley E, Kramer AF, Colcombe SJ. Cardiovascular fitness and neurocognitive function in older adults: a brief review. Brain Behav Immun (2004) 18(3):214-20.

5. Coubard OA, Duretz S, Lefebvre V, Lapalus P, Ferrufino L. Practice of contemporary dance improves cognitive flexibility in aging. Front Aging Neurosci (2011) 3(13):1-12. Epub 2011 Sep 20.

6. Toskovic N, Blessing D, Williford HN. Physiologic profile of recreational male and femal novice and experienced Tae Kwon Do practicioners. J Sports Med Phys Fittness (2004) 44(2):164-72.

7. Man DW, Tsang WW, Hui-Chan CW. Do older t'ai chi practitioners have better attention and memory function? J Altern Complement Med (2010) 16(12):1259-64.

8. Lam LC, Chau RC, Wong BM, Fung AW, Lui VW, Tam CC, Leung GT, Kwok TC, Chiu HF, Ng S, Chan WM. Interim follow-up of a randomized controlled trial comparing Chinese style mind body (Tai Chi) and stretching exercises on cognitive function in subjects at risk of progressive cognitive decline. Int J Geriatr Psychiatry (2011) 26(7):733-40.

9. Pons van Dijk G, Leffers P, Lodder J. Feasibility, safety and subjective experience of a one-year WTF-Taekwondo training course for middle-aged volunteers; the Sekwondo study. Gazz Med ItalArch Sci Med (2013) 172(6):433-41.

10. Wolter LL, Studenski SA. A clinical synthesis of falls intervention trials. Top Geriatr Rehabil (1996) 11:9-19.

11. Pons van Dijk G, Lenssen AF, Leffers $\mathrm{P}$, Kingma $\mathrm{H}$ and Lodder J. Taekwondo training improves balance in volunteers over forty. Front Ag Neurosci (2013) 5(10). Epub Epub 2013 Mar 13. doi: 10.3389/fnagi.2013.00010.

12. http://www.wtf.org/.

13. Lodder J. Sekwondo. WTF-Taekwondo voor beginners boven 40 jaar. Een sportdidactische handleiding voor trainer en beginner. (2012).

14. Schufried G. Vienna Test System WAF - Perception and attention functions. http://wwwschuhfriedcom/vienna-test-system-vts/all-tests-from-a-z/test/rt-reaction-test/ (2001).

15. Wechsler. WAIS III, nederlandstalige bewerking: technische handleiding. Lisse: Swets Test Publishers (2001).

16. Lezak MD, Howieson DB, Loring DW. Neuropsychological Assessment (4th ed.). New York: Oxford University Press (2004). 
17. Reitan R. Trail Making test: Manual for administration, scoring, and interpretation. Bloomington: Indiana University (1956).

18. Martinez JD, Caraway C. Combat mine; a non-violent approach to stage violence. Rowman and Littlefield Pub Inc (1982):7-8.

19. Pons van Dijk G, Leffers P and Lodder J. The efficacy of hard martial arts in older adults: a systematic review. Under submission (2013).

20. Chateau-Degat M-L, Papouin G, Saint-Val P, Lopez, A. Effect of adapted karate training on quality of life and body balance in 50-year-old men. Open Access Journal of Sports Medicine (2010) 1:143-50.

21. Smith PJ, Blumenthal JA, Hoffman BM, Cooper H, Strauman TA, Welsh-Bohmer K, Browndyke JN and Sherwood A. Aerobic exercise and neurocognitive performance: a meta-analytic review of randomized controlled trials. Psychosomatic medicine (2010) 72(3):239-52. doi: 10.1097/PSY.0b013e3181d14633. PubMed PMID: 20223924; PubMed Central PMCID: PMC2897704.

22. Chang JY, Tsai PF, Beck C, Hagen JL, Huff DC, Anand KJ, Roberson PK, Rosengren KS, Beuscher L. The effect of tai chi on cognition in elders with cognitive impairment. Medsurg Nurs (2011) 20(2):63-9.

23. Albinet $\mathrm{CT}$, Boucard G, Bouquet CA, Audiffren M. Processing speed and executive functions in cognitive aging: How to disentangle their mutual relationship? Brain Cogn (2012) 79(1):1-11. Epub 2012 Mar 2.

24. Salthouse TA. The processing-speed theory of adult age differences in cognition. Psychological Review (1996) 103(3):403-28.

25. Chan AS, Ho YC, Cheung MC, Albert MS, Chiu HF, Lam LC. Association between mind-body and cardiovascular exercises and memory in older adults. J Am Geriatr Soc (2005) 53(10):1754-60.

26. Lam LC, Tam CW, Lui VW, Chan WC, Chan SS, Chiu HF, Wong A, Tham MK, Ho KS, Chan WM. Modality of physical exercise and cognitive function in Hong Kong older Chinese community. Int J Geriatr Psychiatry (2009) 24(1):48-53.

27. Kaduszkiewicz H, Zimmermann T, Beck-Bornholdt HP, van den Bussche H. Cholinesterase inhibitors for patients with Alzheimer's disease: systematic review of randomised clinical trials. $B M J$ 2005 (2005) 331:321-7.

28. Tariot PN, Farlow MR, Grossberg GT, Graham SM, McDonald S, Gergel I. Memantine Study Group. Memantine treatment in patients with moderate to severe Alzheimer disease already receiving donepezil: a randomized controlled trial. JAMA (2004) 291:317-24. 


\section{5}

Effect of Taekwondo training on muscle strength and physical fitness in middle-aged volunteers: The Sekwondo study

G. Pons van Dijk, A.F. Lenssen and J. Lodder.

Not published 


\section{Abstract}

A low level of physical activity relates to an increased risk of cardiovascular disease, diabetes mellitus, osteoporosis, and has a negative effect on mood, cognitive functions and overall wellbeing. With increasing age these negative consequences lead to deterioration of mobility, jeopardizing selfmaintenance, and increase the chance to become dependent on others.

We studied the effects of age-adapted Taekwondo training of one hour a week, during one year, in 24 healthy middle-aged volunteers on hamstrings and quadriceps strength, treadmill run, including in units of metabolic equivalents (MET), six minute walking test, a running test, and a questionnaire.

There was no significant improvement in strength nor in cardio fitness, but neither was there a decline as expected with one year age increase. A questionnaire showed a subjective improvement in 30-50 percent of the compliers, and no change in the non-complier group.

In conclusion, our data at least suggest that age-adapted Taekwondo training may stabilize cardiorespiratory physical fitness and muscle strength in healthy people over the age of 40 . 


\section{Introduction}

The American College of Sport Medicine (ACSM) estimated that about 60 percent of Americans lack sufficient daily exercise, while about 25 percent has almost none ${ }^{1}$. In the Netherlands, about 25 percent of people lack sufficient daily physical activity, and about $10 \%$ do not exercise at all ${ }^{2-3}$. A low level of physical activity relates to an increased risk of cardiovascular disease, diabetes mellitus, osteoporosis, and has a negative effect on mood, cognitive functions and overall wellbeing. With increasing age these negative consequences lead to deterioration of mobility, jeopardizing self-maintenance, and increase the chance to become dependent on others ${ }^{4-6}$.

Exercise programs, including those based on martial arts, lower the chance of a number of negative consequences of aging ${ }^{4-7}$. Most conducted research on martial arts focuses on Tai Chi, which contains slow controlled movements, where performers gradually shift between standing postures and slow movements of the upper extremities ${ }^{8}$. Several studies on Tai Chi have showed benefits in cardiorespiratory status, improvement in muscular strength and endurance in elderly individuals, and even on cardiorespiratory function in patients who had coronary bypass surgery ${ }^{9-11}$. However, Taekwondo contains kicking, blocking and striking techniques with power to hit a target, which, apart from a certain degree of technique, requires both muscle strength and speed of execution.

A review of 23 studies on effects on physical functions of Taekwondo training suggested some benefits on aerobic capacity, body composition and flexibility. However, this review was descriptive and considered no age specification ${ }^{12}$. In this study we sought to study any effect of Taekwondo practice on certain physical fitness components and on muscle strength in people over 40 . If shown to be effective, such practice could then be recommended as an effective, safe and cost-effective method to improve certain health-related physical functions for people in this age category.

\section{Methods}

Study methods were described in detail elsewhere ${ }^{13}$, so only relevant details are presented here. The study was a single arm intervention study in which participants served as their own control.

Study population: Healthy male and female volunteers, 40-75 years of age. Inclusion criteria: willingness to follow at least a one hour Taekwondo training session weekly. All volunteers had a routine neurological and cardiologic physical investigation and an exercise ECG. Exclusion criteria: Current psychiatric treatment, the use of oral anticoagulants and/or any disease that was expected to interfere with training, as judged by the volunteer's treating physician, the study neurologist (JL), or study cardiologist.

Recruitment and consent: Posters inviting people for participation were posted at various locations in the Maastricht Hospital and University buildings. Interested people were informed by oral and 
written information, and they were encouraged to follow at least two Taekwondo sessions at the trainers' Taekwondo club before enrolment.

Training sessions: Training intensity was adjusted to the participants' physical condition. The sessions lasted about one hour, and generally consisted of the following elements: a short warming-up; Taekwondo techniques, such as stances, blockings, kicks, punches, and strikes; poomsae (style figures), which are fixed patterns, illustrating a fight against one or more imaginary opponents; some elementary self-defence Taekwondo techniques. As Taekwondo combat sparring was considered injury prone, such practice was not included. For details on the program we refer to ${ }^{13}$. The first training session took place on 21 October, 2009, and the final one on 19 January, 2011. We aimed at 40 lessons for each participant within one year, but because the attendance rate was lower than anticipated, we decided to extent the training period with three months. During the study, several participants chose to follow additional Taekwondo lessons at our Taekwondo club facility, where we adapted the club training program to comply with the study protocol. Number of lessons at the two locations was recorded separately.

Withdrawal: Subjects could leave the study at any time without any obligation to reveal their reasons, but we listed such reasons to evaluate the feasibility of the training program. We encouraged study participation by creating an informal atmosphere, and we reserved ample time for feedback.

Measurements: All participants were tested in the month before the start of the study, and as soon as possible after the last training session.

Strength measurements were performed using the Biodex System 3 Pro dynamometer (Biodex Medical Systems, Shirley, New York, USA), which is a reliable and valid instrument ${ }^{14}$. We measured isokinetic peak torques (in $\mathrm{Nm}$ ) of the hamstrings and quadriceps muscles of the dominant leg, with a movement arm velocity of 60 and $180^{\circ}$ per second. We also measured isometric peak torques with the knee flexed 30 and $60^{\circ}$ as described previously ${ }^{15}$.

Physical fitness was measured using: 1) treadmill run: participants underwent a symptom-limited treadmill test according to the Bruce protocol with exercise ECG registration ${ }^{16-17}$. We recorded heart rate and blood pressure, and performed a 12-lead ECG just before the exercise, at the end of each exercise stage, at peak exercise, and at 1-minute intervals during recovery. The test was discontinued for limiting symptoms (angina, dyspnea, and fatigue), abnormalities of rhythm or blood pressure, or marked and progressive ST-segment deviation. Target heart rates were not used as a predetermined end point.

Exercise capacity is expressed in units of metabolic equivalents (MET) and is an estimate of the maximal oxygen uptake for a given workload ${ }^{18}$. A MET is a measure of ventilatory oxygen consumption expressed as multiples of basal resting requirements, where $1 \mathrm{MET}$ is 1 unit of basal oxygen consumption, which equals $3.5 \mathrm{~mL}$ oxygen consumption per kilogram of body weight per 
minute for an average adult. The exercise capacity (in MET) is estimated by the speed and grade of the treadmill ${ }^{1}$.

2) Six-minute walk: subjects were instructed to walk around a rectangular track as many times as possible during a period of 6 minutes at a fast but safe speed. The track was set up in an area of approximately 12 meters by 10 meters (in total 44 meters of distance). Plastic cones marked the corners of the track, indicating where the subject changed direction, which was always turning 90 degrees left. Participants were instructed as stated in the protocol of the American Thoracic Society ${ }^{20}$. The distance traveled was recorded in meters after completion ${ }^{20}$.

3) Running test: subjects were instructed to walk or run a rectangular track and to complete three laps of this track, in total 132 meters, as fast as possible in a for them comfortable speed.

Questionnaire: A questionnaire on the participants' subjective assessment on various aspects of the program was conducted at the end of the training period. There were two questions relevant to strength and physical fitness:

Since I started practicing Taekwondo training:

- my muscle power is:

- my feeling of physical fitness is:

(answer options: much worse / worse / unchanged / better / much better).

Statistics: Wilcoxon Signed-Rank Test and paired T-tests (SPSS, version 17.0, SPSS Inc., Chicago, IL) was used to compare the parameters. A p-value $<0.05$ was considered statistically significantly. For sample size estimation see reference ${ }^{13}$.

\section{Results}

24 volunteers participated, 12 men and 12 women, with a mean age of $55.6 \pm 7.0$ years (range 41-71 years, median 57 years).

Three women and two men withdrew early from the training program (non-compliers). In two the reason was training related, in two due to external reasons, and in the fifth a combination of both. The demographic characteristics of the non-compliers did not differ significantly from those completing the study ${ }^{21}$, see table 1 .

All participants did have all baseline and final measurements, so there were no real study dropouts. However, the measurements of strength and the 6 minute walk could only be registered in 17 out of 19 compliers. One complier missed the baseline test because of reluctance to maximal physical exercise, and the other missed the final test due to a non-training related shoulder injury. All participants completed both baseline and final test of the treadmill run.

Results for baseline and final test measurements are shown in table 2, 3 and 4. 
Table 2 shows the group mean $( \pm S D)$ muscle strength outcome at baseline and at one year for the various muscle strength measurement. Apart from a significant lower value for 30 degree isometric

\begin{tabular}{|c|c|c|c|c|}
\hline $\mathrm{Nr}$ & Gender & Age & $\begin{array}{c}\text { Education } \\
\text { level }\end{array}$ & $\begin{array}{c}\text { Physical } \\
\text { activity (hrs/wk) }\end{array}$ \\
\hline 1 & $m$ & 61 & $U$ & 15 \\
\hline 2 & $\mathrm{~m}$ & 61 & U & 10 \\
\hline 3 & $\mathrm{~m}$ & 62 & $U$ & 0 \\
\hline 4 & $\mathrm{~m}$ & 59 & $U$ & 7 \\
\hline 5 & $f$ & 41 & $U$ & 0 \\
\hline 6 & $\mathrm{~m}$ & 58 & $U$ & 9 \\
\hline 7 & $\mathrm{~m}$ & 51 & $U$ & 4 \\
\hline 8 & $f$ & 49 & $\mathrm{H}$ & 3 \\
\hline 9 & $f$ & 60 & U & 10 \\
\hline 10 & $\mathrm{~m}$ & 66 & 0 & 10 \\
\hline 11 & $f$ & 50 & $\mathrm{H}$ & 5 \\
\hline 12 & $\mathrm{~m}$ & 57 & $U$ & 4 \\
\hline 13 & $f$ & 51 & $\mathrm{H}$ & 3 \\
\hline 14 & $f$ & 63 & U & 0 \\
\hline 15 & $\mathrm{~m}$ & 70 & $U$ & 2 \\
\hline 16 & $\mathrm{~m}$ & 53 & $U$ & 5 \\
\hline 17 & $f$ & 50 & $\mathrm{H}$ & 5 \\
\hline 18 & $\mathrm{~m}$ & 52 & $\mathrm{H}$ & 3 \\
\hline 19 & $f$ & 57 & $\mathrm{H}$ & 4 \\
\hline 20 & $\mathrm{~m}$ & 59 & U & 0 \\
\hline 21 & $f$ & 60 & U & 1 \\
\hline 22 & $f$ & 44 & $\mathrm{H}$ & 10 \\
\hline 23 & $f$ & 51 & $\mathrm{H}$ & 1 \\
\hline 24 & $f$ & 48 & U & 0 \\
\hline
\end{tabular}

Table 1. Participants demograhics.

$\mathrm{U}=$ master degree or equivalent $\mathrm{H}=$ bachelor degree or equivalent $\mathrm{O}=$ other $\mathrm{Grey}=$ non-complier

quadriceps measurement at one year, there were no statistically different changes. Some people had an increase, some a decrease in various measurements, but no consistent pattern emerged as to a clear increase or decrease of muscle strength in individual participants. For individual changes see table 3. Concerning quadriceps muscle measurements, 6 participants showed a strength increase on isometric testing at 30 degrees with a median of $10 \mathrm{Nm}$ (range 3-32), and 11 a decrease with $29 \mathrm{Nm}$ (range 6-61), $\mathrm{p}=0.003$. Nine participants showed a strength increase with $6.3 \mathrm{Nm}$ (range 3.1-46.1) on isokinetic testing at 60 degrees, and 8 a decrease with $22 \mathrm{Nm}$ (range 4.1-69.8). Nine participants showed a strength increase with $2.8 \mathrm{Nm}$ (range $0.2-7.6$ ) on 180 degrees isokinetic testing, and 8 a decrease with $4.6 \mathrm{Nm}$ (range 1.9-15).

Concerning hamstring muscle measurements, 12 participants showed a strength increase with a median of $6.7 \mathrm{Nm}$ (range 0.6-35.2) at 30 degree isometric testing, and 5 a decrease with a median of 13.4 Nm (range 3.7-23.1). Nine participants showed an increase with a median of $10.9 \mathrm{Nm}$ (range 
0.5-24.9) on 60 degree isometric testing, and 8 a decrease with a median of $8.2 \mathrm{Nm}$ (range 2.3-19.2). Ten participants showed an increase with $9.5 \mathrm{Nm}$ (range 1-46) on 60 degree isokinetic testing, and 7 a decrease with a median of $13 \mathrm{Nm}$ (range 1-42). Eleven participants showed an increase with 5.1 $\mathrm{Nm}$ (range 0.2-19.3) on 180 degree isokinetic testing, and 6 a decrease with $4.7 \mathrm{Nm}$ (range 2.449.8).

\begin{tabular}{|c|c|c|c|c|c|c|}
\hline Measurement & Pre & SD & Post & SD & Significance & $95 \% \mathrm{Cl}$ \\
\hline \multicolumn{7}{|l|}{ Isometric } \\
\hline \multicolumn{7}{|l|}{ Quadriceps } \\
\hline $60^{\circ}$ & 156.45 & 65.8 & 154.54 & 55.4 & 0.68 & $-8.0-11.8$ \\
\hline $30^{\circ}$ & 98.89 & 41.8 & 85.01 & 25.8 & 0.03 & $1.1-6.6$ \\
\hline \multicolumn{7}{|l|}{ Hamstrings } \\
\hline $60^{\circ}$ & 96.26 & 31.5 & 98.6 & 29.5 & 0.48 & $-9.2-4.6$ \\
\hline $30^{\circ}$ & 107.24 & 38.9 & 109.8 & 36.5 & 0.49 & $-10.5-5.3$ \\
\hline \multicolumn{7}{|l|}{ Isokinetic } \\
\hline \multicolumn{7}{|l|}{ Quadriceps } \\
\hline $60^{\circ}$ & 133.26 & 54.2 & 125.24 & 33.6 & 0.26 & $-6.6-22.6$ \\
\hline $180^{\circ}$ & 90.17 & 27.1 & 91.05 & 32.1 & 0.41 & $-1.9-4.3$ \\
\hline \multicolumn{7}{|l|}{ Hamstrings } \\
\hline $60^{\circ}$ & 86.88 & 28.5 & 85.65 & 25.6 & 0.86 & $-11.5-9.7$ \\
\hline $180^{\circ}$ & 67.31 & 22.4 & 67.13 & 15.4 & 0.96 & $-7.5-7.8$ \\
\hline
\end{tabular}

Table 2. Strength in peak Torque $\mathrm{Nm}$, mean

\begin{tabular}{|c|c|c|c|c|c|c|c|c|c|c|c|c|c|c|c|c|c|}
\hline Measurement & 1 & 2 & 3 & 4 & 5 & 6 & 7 & 8 & 9 & 10 & 11 & 12 & 13 & 14 & 15 & 16 & 17 \\
\hline \multicolumn{18}{|l|}{ Isometric } \\
\hline \multicolumn{18}{|l|}{ Quadriceps } \\
\hline $60^{\circ}$ & 8,3 & $-4,7$ & 20,4 & $-41,8$ & $-15,8$ & $-17,8$ & 33,6 & 5,4 & $-0,9$ & 2,6 & 23 & 17,9 & $-13,3$ & $-23,1$ & 4,6 & $-15,4$ & $-15,5$ \\
\hline $30^{\circ}$ & -6 & -25 & -8 & -46 & -29 & -29 & 18 & 3 & 15 & -40 & 5 & 4 & -19 & -30 & 32 & -61 & $-22,8$ \\
\hline \multicolumn{18}{|l|}{ Hamstrings } \\
\hline $60^{\circ}$ & $-3,1$ & 0,5 & 7,6 & 1,7 & $-10,6$ & $-2,3$ & 24,8 & $-15,7$ & 2,7 & $-6,3$ & 17,1 & $-10,1$ & $-19,2$ & 10,9 & $-2,9$ & 24,9 & 19,6 \\
\hline $30^{\circ}$ & $-3,7$ & 4,9 & 0,6 & 6,3 & 21,8 & $-11,2$ & 16,6 & $-15,5$ & 7,1 & $-17,2$ & 11 & 0,7 & $-23,1$ & $-8,9$ & 18,8 & 35,2 & 0,7 \\
\hline \multicolumn{18}{|l|}{ Isokinetic } \\
\hline \multicolumn{18}{|l|}{ Quadriceps } \\
\hline $60^{\circ}$ & $-4,1$ & 0 & 20,4 & $-39,1$ & $-58,8$ & 3,1 & 6,1 & 12,7 & 6,5 & -16 & $-21,5$ & $-22,5$ & 4,3 & $-69,8$ & 46,1 & 4,2 & -8 \\
\hline $180^{\circ}$ & $-3,4$ & $-2,2$ & 1,6 & 0,2 & $-5,3$ & 7,6 & 4,4 & 4,7 & 4,3 & $-4,4$ & $-1,9$ & 2,5 & $-4,8$ & -15 & 0,7 & 2,8 & $-12,6$ \\
\hline \multicolumn{18}{|l|}{ Hamstrings } \\
\hline $60^{\circ}$ & -10 & -1 & 7 & -23 & -42 & -1 & 26 & 6 & 1 & 0 & 16 & 9 & -13 & 46 & 11 & 10 & $-28,2$ \\
\hline $180^{\circ}$ & $-2,4$ & 2,7 & 0,2 & $-12,3$ & $-49,8$ & 5,1 & 16,4 & 3,5 & 6,6 & 8,5 & 2,3 & 6,7 & $-2,5$ & $-4,6$ & 1,9 & 19,3 & $-4,8$ \\
\hline
\end{tabular}

Table 3. Change in strength per participant in peak Torque $\mathrm{Nm}$ 
At the treadmill walk 9 participants had a MET increase of 1.7 (range 0.1-7.9) and 8 participants a decrease of 1.7 MET (range 0.2-4.6); differences not being statistically significant (table 4).

The 6 minute walking distance increased with 8.4 meters, whereas the MET increased with 0.4; both differences not being statistically significant (table 3 ). Nine participants showed an increase with a median of 59 meters (range 4-97), and 8 participants a decrease with a median of 25.5 meters (range 10-88).

The track running time, as measured for the whole group, increased (not statistically significant) with 2 seconds. Eleven participants showed an increase with a median of 5 seconds (range 2-22), and 6 participants decreased with 8.5 seconds (range 1-34).

The questionnaire showed a subjective increase of strength in one third of the participants (6 out of 19) and an increase in physical fitness in 9 of 19, see table 5 . The group of non-compliers reported no increase in both aspects. We were unable to establish a correlation between the subjective and objective changes in strength and physical fitness.

\begin{tabular}{lccccc}
\hline Measurement & Pre & SD & Post & SD & Significance \\
\hline 6MWT (m) & 696.12 & 55.7 & 704.53 & 38.1 & 0.49 \\
Running (s) & 90.47 & 11.1 & 88.65 & 9.7 & 0.59 \\
MET & 14.28 & 2.6 & 14.47 & 2.3 & 0.76 \\
\hline
\end{tabular}

Table 4. Endurance, mean. 6MWT: 6 minutes walking test

total much worse worse unchanged better much better

\begin{tabular}{lllllll}
\hline my feeling of physical fitness is: & 19 & 0 & 0 & 10 & 9 & 0 \\
my muscle power is: & 19 & 0 & 0 & 13 & 6 & 0 \\
\hline
\end{tabular}

Table 5. outcome of questionnaire.

\section{Discussion}

Our study showed that a weekly 1 hour Taekwondo training for the duration of 15 months did not affect strength measures in healthy volunteers over 40 . The only statistically significant change, a decrease in 30 degrees quadriceps strength, could be a random effect, or due to an internal measurement error, inherent to the test itself, as we were unable to find any consistency in the muscle strength measurement data. Our data only suggest improvement of hamstring muscle strength, but it failed statistical significance. We also failed to show an effect on cardio fitness as measured by treadmill testing.

There are several studies which showed that the force generating capacity of human muscles decline with increasing age ${ }^{22-24}$. Such decline is not only explained by reduced physical activity but also, in greater extent, to a reduction in muscle mass independent from such activity ${ }^{25-26}$. One of the main 
components of Taekwondo is fast and powerful kicking, which requires adequate muscle power, as does performance of various stances ${ }^{28}$. Several studies have analyzed muscle strength in Taekwondo athletes and observed an improvement of knee flexion and in a lesser degree knee extension related to muscle strength ${ }^{25,26,28}$. Such improvement was most prominent in studies with hard martial arts athletes who competed in sparring competitions. Studies in Japan and the United states indicated that with each year of aging there is a loss of isokinetic muscle strength ranging from 0.88 to $1.8 \mathrm{NM}$ 15,29 . Our strength measurement data are rather non-homogeneous, and any conclusion about strength differences as an effect of the study training program, therefore, speculative. Especially sparring exercises may be expected to increase leg muscles strength. Our primary study endpoint was balance, to which the exercises were tuned to in particular, whereas we refrained from sparringspecific training because of the age of our study group. Therefore, clear strength improvement may not have occurred. The absence of increased strength by the training program may be explained by the fact that the participants, related to other physical training activities, already had developed increased muscle strength which was unlikely to increase further by one extra hour a week of the program(see Table 1).

There are several studies on physical fitness in elite Taekwondo practitioners, which show a high maximum oxygen uptake (VO2max), but because of the high training level of these athletes these findings do not reliably reflect any effect of Taekwondo training in the general population ${ }^{27}$. Comparing the physiological profile of recreational and advanced Taekwondo practitioners Toskovic et al. found better aerobic power in the advanced group ${ }^{30}$.

We found a minor increase of distance in the $6 \mathrm{MWT}$, shorter time in the running test, and steady state in MET.

These results may be explained by the already high physical fitness level of our participants before they started to participate (table 1). Furthermore, the fact that intensive sparring training was not part of our program makes it conceivable not to expect significant improvement of cardio-respiratory physical fitness component measures.

The 6MWT increased in our study with an average of 8.41 meters. Several studies have compared change in the 6MWT due to aging one year, on the basis of which formulas have been calculated. Normally in 1 year aging there is a decline, ranging from 3.6 to 7.8 meters ${ }^{31-32}$. Taking this in account, an increase of 8.41 meters in one year seems an improvement, respectively unchanged instead of the expected deterioration. However in most randomized controlled studies an improvement has been defined as 50 meters or more, a difference we did not detect ${ }^{33}$.

Our study has limitations, one of which is the absence of a control group. However, as we did not expect performances to improve with another year of aging, participants functioned as their own controls. Because our primary outcome measure was balance there was less emphasis on the training of cardio-respiratory fitness and thus the results can be an underestimation. Furthermore 
our participants already were physically active, which may have limited the possibility for significant further improvement of these physical fitness parameters.

The early withdrawal of five participants could be regarded as a study drawback, but these five still completed follow-up measurements, and are "non-compliers" and not study dropouts. Moreover, based on our sample size estimation for the primary outcome measure, which was a balance parameter, eventual complete study adherence in 17 would suffice.

In conclusion, our data suggest that age-adapted Taekwondo training may stabilize and perhaps even improve cardio-respiratory physical fitness and strength in healthy people over the age of 40 . Recently we reported on the feasibility and safety of our training program ${ }^{13}$. Whether long-term adherence to age-adapted Taekwondo training indeed has a beneficial effect on mobility and fall accident frequency in people with a higher age remains for further study. 


\section{References}

1. American College of Sports Medicine. ACSM'S resource manual for guidelines for exercise testing and prescription, 6th ed. Philadelphia: Lippincott Williams and Wilkins,, 2001: p. 5790.

2. Kroes $\mathrm{G}$ and Greef de M. National initiatives for the promotion of physical activity for older persons in the Netherlands. Journal of Aging and Physical Activity 2000. 8: p. 431-435.

3. Lobstein T, Rigby $\mathrm{N}$ and Leach R. EU Platform on diet, physical activity and health. http://ec.europa.eu/health/ph determinants/life style/nutrition/documents/iotf en.pdf., 2005.

4. Cress ME, Buchner DM, Questad KA, Esselman PC, deLateur BJ, Schwartz RSA. Exercise : effects on physical functional performance in independent older adults. J gerontol Med Sci. , 1995. 54A: p. 242-248.

5. Buchner D, Cress ME, deLateur BJ, Esselman PC, Margherita AJ, Price R and Wagner EH. A comparison of the effects of three types of endurance training on balance and other fall risk factors in older adults. Aging Clin Exp Res 1997. 9: p. 112-119.

6. Cameron ID, Gillespie LD, Robertson MC, Murray GR, Hill KD, Cumming RG, Kerse N. Interventions for preventing falls in older people in care facilities and hospitals. Cochrane Database Syst Rev. 2012 Dec 12;12:CD005465. doi: 10.1002/14651858.CD005465.pub3., 2012. 12(12).

7. Cromwell RL, Meyers PM, Meyers PE, Newton RA. Taekwondo: An effective exercise for improving balance and walking ability in older adults J of Gerontol: Medical Sciences., 2007. 62A(6): p. 641-646.

8. Corcoran J, Farkas E, Sobel S. The Origina IMartial Arts Encyclopedia: Tradition, History, Pioneers; Pro-Action Publications: Los Angeles,USA, 1993.

9. Hong Y, Li XJ, Robinson PD. Balance control, flexibilty, and cardiorespiratory fitness among older tai chi practitioners. Br J Sports Med, 2000. 34: p. 24-29.

10. Lan C, Lai JS, Chen SY, Wong MK. Tai chi chuan to improve muscular strength and endurance in elderly individuals: a pilot study. Arch Phys Med Rehabil, 2000. 81: p. 604-607.

11. Maciaszek J, Osiński W. The effects of Tai Chi on body balance in elderly people--a review of studies from the early 21st century. Am J Chin Med. , 2010. 38(2): p. 219-229.

12. Fong SS, Ng GY. Does Taekwondo training improve physical fitness? Phys Ther Sport., 2011. 12(2): p. 100-106. 
13. Pons van Dijk G, Leffers P and Lodder J. Feasibility, safety and subjective experience of a oneyear WTF-Taekwondo training course for middle-aged volunteers; the Sekwondo study. Gazz Med Ital-Arch Sci Med 2013. 172(6): p. 433-441.

14. Drouin JM, Valovich-mcLeod TC, Shultz SJ, Gansneder BM, Perrin DH. Reliability and validity of the Biodex system 3 pro isokinetic dynamometer velocity, torque and position measurements. Eur J Appl Physiol. , 2004. 91(1): p. 22-29.

15. Freedson PS, Gilliqm TB, Mahoney T, Maliszewski AF, Kastango K. Industrial torque levels by age group and gender. Isokinet Exerc Sci 1993. 3: p. 34-42.

16. Ellstad M. Stress Testing: Principles and Practice. Philadelphia, Pa: FA Davis, 1995.

17. Schlant RC, Blomqvist CG, Brandenburg RO, DeBusk R, Ellestad MH, Fletcher GF, Froelicher VF $\mathrm{Jr}$, Hall RJ, McCallister BD, McHenry PL, et al. Guidelines for exercise testing. A report of the Joint American College of Cardiology/American Heart Association Task Force on Assessment of Cardiovascular Procedures (Subcommittee on Exercise Testing). Circulation, 1986. 74(3): p. 653-667.

18. Bruce RA, Kusumi F, Hosmer D. Maximal oxygen intake and nomographic assessment of functional aerobic impairment in cardiovascular disease. Am Heart J. , 1973. 85: p. 546-562.

19. ATS Committee on Proficiency Standards for Clinical Pulmonary Function Laboratories. ATS statement: guidelines for the six-minute walk test. . Am J Respir Crit Care Med 2002. 166: p. 111-117.

20. Solway S, Brooks D, Lacasse $Y$ and Thomas S. A qualitative systematic overview of the measurement properties of functional walk tests used in the cardiorespiratory domain. Chest 2001. 119: p. 256-270.

21. Pons van Dijk G, Lenssen AF, Leffers $\mathrm{P}$, Kingma $\mathrm{H}$, Lodder J. Taekwondo training improves balance in volunteers over forty. Front. Ag. Neurosci., 2013. 5(10).

22. Frontera WR, Hughes VA, Lutz KJ, Evans WJ. A cross-sectional study of muscle strength and mass in45- to 78-yr-old men and women. J Appl Physiol, 1991. 71: p. 644-650.

23. Hakkinen $\mathrm{K}$, Alen $\mathrm{M}$, Kallinen $\mathrm{M}$, Izquierdo $\mathrm{M}$, Jokelainen $\mathrm{K}$, Lassila $\mathrm{H}$, Malkia E, Kraemer WJ, Newton RU. Muscle CSA, force production, and activation of leg extensors during isometric, and dynamic actions in middle-ages, and elderly me, and women. J Aging Phys Act, 1998. 6: p. 232-247.

24. Proctor DN, Balagopal P, Nair KS. Age-related sarcopenia in humans is associated with reduced synthetic rates of specific muscle proteins. J Nutr, 1998. 128: p. 351-355.

25. Pieter W. Isokinetic leg strength of Taekwondo practicioners. Asian J Phys Educ, 1989. 12: p. 55-64. 
26. O'Donovan O, Cheung J, Catley M, McGregor AH, Strutton PH. An investigation of leg and trunk strength and reaction times of hard-style martial arts practicioners. J Sports Sci Med., 2006. 5: p. 5-12.

27. Fong SSM, Ng GY. Does Taekwondo training improve physical fitness? Phys Ther Sport., 2011. 2: p. 100-106.

28. Cetin C, Kececi AD, Erdogan A, Baydar ML. Influence of custom-made mouth guards on strength, speed and anaerobic performance of taekwondo athletes. Dent Traumatol., 2009. 25: p. 272-276.

29. Marcellis RG, Lenssen AF, Elfferich MD, De Vries J, Kassim S, Foerster K, Drent M. Exercise capacity, muscle strength and fatigue in sarcoidosis. Eur Respir J., 2011. 38(3): p. 628-634.

30. Toskovic N, Blessing D, Williford HN. Physiologic profile of recreational male and femal novice and experienced Tae Kwon Do practicioners. J Sports Med Phys Fittness. , 2004. 44(2): p. 164172.

31. Beekman E, Mesters I, Gosselink R, Klaassen MP, Hendriks EJ, Van Schayck OC, de Bie RQ. The first reference equations for the 6-minute walk distance over a $10 \mathrm{~m}$ course. Thorax. , 2014. 69(9): p. 867-868.

32. Troosters $\mathrm{T}$, Gosselink R, Decramer M. Six minute walking distance in healthy elderly subjects. Eur Respir J., 1999. 14(2): p. 270-274.

33. Gibbons WJ, Fruchter N., Sloan S, Levy RD. Reference values for a multiple repetition 6minute walk test in healthy adults older than 20 years. J Cardiopulm Rehabil, 2001. 21(2): p. 87-93. 


\section{Effects of one year Taekwondo training on flexibility in novices over 40. The Sekwondo study}

G. Pons van Dijk, A.F. Lensen and J. Lodder. 


\section{Abstract}

One of the components of physical fitness in middle-aged and senior adults is flexibility, which is of importance for executing and sustaining motor activities in daily life. Flexibility declines with age, starting at approximately 40 years. A decrease of flexibility may also affect gait and lead to an increased risk of falls, whereas it may also increase the susceptibility to musculoskeletal injuries.

One of the main components of Taekwondo consists in the performance of high kicks, which are full range movements at high speed, requiring a high degree of flexibility for skillful performance. In this study we sought to investigate whether age-adapted Taekwondo training of one hour a week during one year, improves flexibility in people over 40 , measured using a sit and reach flexibility box and by measuring fingertip-to-floor distance.

This study shows a trend of improvement in flexibility in spine and pelvis flexibility in healthy volunteers over 40 . We observed a (statistically significant) improvement in the fingertip-to-floor distance, but no change in the sit and reach flexibility test. More than $50 \%$ of the compliers experienced an improvement in flexibility, while none of them reported a deterioration. The noncompliers reported no changes.

In conclusion, our data suggest that age-adapted Taekwondo training improves lower body flexibility in healthy people over the age of 40 . Our findings concur with the subjective experience that when Taekwondo training programs are more specifically directed at flexibility improvement, improved flexibility will ensue. 


\section{Introduction}

One of the components of physical fitness in middle-aged and senior adults is flexibility, which is of importance for executing and sustaining motor activities in daily life ${ }^{1,2}$.

Flexibility declines with age, starting at approximately 40 years. Because of tightened hamstrings and lowered flexibility in the hip and lower back musculature, there are biomechanical changes in the pressure distribution in the spine which may lead to consequent spinal disorders ${ }^{3}$. A decrease of flexibility may also affect gait and lead to an increased risk of falls, whereas it may also increase the susceptibility to musculoskeletal injuries ${ }^{3,4}$.

One of the main components of Taekwondo consists in the performance of high kicks, which are full range movements at high speed, requiring a high degree of flexibility for skillful performance.

A review of 23 studies on effects of Taekwondo training on physical functions included six studies regarding flexibility ${ }^{5}$. However, this review was descriptive and only one of those studies (Cromwell et al) contained older adults ${ }^{5,6}$. The only other study which examined flexibility in older adults was that by Brudnak et al., however all participants of their control group dropped out ${ }^{7,8}$.

In this study we sought to investigate whether Taekwondo practice improves flexibility in people over 40, measured using a sit and reach flexibility box and by measuring fingertip-to-floor distance. If shown to be effective, Taekwondo practice might be recommended as an effective, safe and costeffective method to improve certain health-related physical functions for people in this age category, including flexibility.

\section{Methods}

Study methods were described in detail elsewhere ${ }^{9}$, so only relevant details are presented here. The study was a single arm intervention study in which participants served as their own control.

Study population: Healthy male and female volunteers, 40-75 years of age. Inclusion criteria: willingness to follow at least a one hour Taekwondo training session weekly. All volunteers had a routine neurological and cardiologic physical investigation and an exercise ECG. Exclusion criteria: Current psychiatric treatment, the use of oral anticoagulants and/or any disease that was expected to interfere with training, as judged by the volunteer's treating physician, the study neurologist (JL), or study cardiologist.

Recruitment and consent: Posters inviting people for participation were posted at various locations in the Maastricht Hospital and University buildings. Interested people were informed by oral and written information, and they were encouraged to follow at least two Taekwondo sessions at the trainers' Taekwondo club before enrolment.

Training sessions: Training intensity was adjusted to the participants' physical condition. The sessions lasted about one hour, and generally consisted of the following elements: a short warming-up; 
Taekwondo techniques, such as stances, blockings, kicks, punches, and strikes; poomsae (style figures), which are fixed patterns, illustrating a fight against one or more imaginary opponents; some elementary self-defence Taekwondo techniques. As Taekwondo combat sparring was considered injury prone, such practice was not included. For details on the program we refer to ${ }^{9}$. The first training session took place on 21 October, 2009, and the final one on 19 January, 2011. We aimed at 40 lessons for each participant within one year, but because the attendance rate was lower than anticipated, we decided to extent the training period with three months. During the study, several participants chose to follow additional Taekwondo lessons at our Taekwondo club facility, where we adapted the club training program to comply with the study protocol. Number of lessons at the two locations was recorded separately.

Withdrawal: Subjects could leave the study at any time without any obligation to reveal their reasons, but we listed such reasons to evaluate the feasibility of the training program. We encouraged study participation by creating an informal atmosphere, and we reserved ample time for feedback.

Measurements: All participants were tested in the month before the start of the study, and as soon as possible after the last training session. $s$ the fingertip-to-floor test,

A sit and reach flexibility box (Figure Finder Flex tester, Novel products inc. ${ }^{10}$ ) was used to assess low back and hip joint flexibility ${ }^{11}$. This test was developed, as emphasized in several studies, to measures specifically hamstring flexibility ${ }^{12,13}$. The test produces reliable scores in middle-aged and older men and women, $r=0.57$ and $r=0.74$ respectively ${ }^{13}$. Each subject sat with legs fully extended with the bare soles of the feet placed flat against the flexibility box. The participant reached forwards with the legs fully extended, arms evenly stretched and palms down. The subjects had to push the sliding marker along the scale with their fingertips, as far as possible. The tests was repeated three times and the best value in centimeters was documented and used for data analysis. A decrease in one or more centimeters represents an improvement.

The fingertip-to-floor distance was measured while standing forward bent and reaching with the hands to the floor. This test evaluates whole spine and pelvis flexibility, and was shown to be very reliable, $r=0.96^{14,15}$.

The distance from the fingertips to the floor was measured in centimeters, a decrease of one $\mathrm{cm}$ or more represents an improvement ${ }^{1116,17}$.

\section{Questionnaire}

A questionnaire on the participants' subjective assessment on various aspects of the program was conducted at the end of the training period. There was one questions relevant to flexibility: 
Since I started practicing Taekwondo training:

- my flexibility is:

(answer options: much worse / worse / unchanged / better / much better).

Statistics: Wilcoxon Signed-Rank Test and paired T-tests (SPSS, version 17.0, SPSS Inc., Chicago, IL) was used to compare the parameters. A p-value $<0.05$ was considered statistically significantly. For sample size estimation see reference ${ }^{9}$.

\section{Results}

There were 24 volunteers, 12 men and 12 women, with a mean age of $55.6 \pm 7.0$ years (range $41-71$ years, median 57 years).

Three women and two men withdrew early from the training program (non-compliers). In two the reason was training related, in two due to external reasons, and in the fifth a combination of both. The demographic characteristics of the non-compliers did not differ significantly from those completing the study ${ }^{9}$. However all participants had all baseline and final measurements, so there were no study dropouts.

The measurements of flexibility in specific could only be registered in 17of the 19 compliers. One complier missed the baseline test because of reluctance to maximal physical exercise at that moment, and the other missed the final test due to a non-training related shoulder injury.

Results for baseline and final test measurements are shown in table 1.

Table 1. Outcome measurements compliers ( $n=17)$

\begin{tabular}{lccccc}
\hline Measurement & Pre & SD & Post & SD & Significance \\
\hline Sit and reach distance & 23.71 & 10.86 & 22.74 & 10.29 & 0.31 \\
Fingertip-to-floor distance & 10.59 & 5.35 & 5.28 & 4.60 & 0.003 \\
\hline
\end{tabular}

Mean in $\mathrm{cm}$

For the whole group flexibility measured in the sit and reach flexibility box decreased (not statistically significant) with $0.97 \mathrm{~cm}$. Thirteen participants showed a decrease with a median of $3.5 \mathrm{~cm}$ (range 0.5 8.5), and four an increase with a median of $2.75 \mathrm{~cm}$ (range 2.5-5.0).

For the non-compliers 2 participant showed no change, one showed a decrease of $3.5 \mathrm{~cm}$ and 2 an increase of 3 and $4 \mathrm{~cm}$. 
The fingertip-to-floor distance decreased for the whole group with $5.31 \mathrm{~cm}(p=0.003)$. In total 13 participants had a diminution with a median of 4.5 (range 1.0-14.5), and four an increase with a median of $1.5 \mathrm{~cm}$ (range $0.5-4.0$ ).

In the non-complier group three participants showed no change in fingertip-to-floor distance, the other two showed an increase of 2 and $5 \mathrm{~cm}$.

The questionnaire showed that 12 of 19 participants (63\%) experience an improvement in flexibility, while none of them reported a deterioration. The non-compliers reported no changes.

\section{Discussion}

Our study showed that a weekly 1 hour Taekwondo training for the duration of 15 months shows a trend of improvement in flexibility in spine and pelvis flexibility in healthy volunteers over 40 . We observed a (statistically significant) improvement in the fingertip-to-floor distance, but no change in the sit and reach flexibility test. This difference in improvement can be explained by two reasons, one is that they measure two different aspects of flexibility. The sit-and-reach test is moderate reliable for measuring hamstrings flexibility ${ }^{13}$, as the fingertip-to-floor test has been known to be reliable in measuring flexibility of the whole spine and pelvis ${ }^{13}$. Any discrepancy in outcome between these two tests may relate to this difference in what they primarily measure. One of the main aspects of Taekwondo are the kicks, in which the aim is to kick at waist height or if possible higher, as we stimulated during the lessons. Furthermore, Taekwondo is a very dynamic sport also in the sense that it contains a lot of directional changes in combination with stances, blocks, punches, and kicks. Performance of such movements definitely require a combination of lower back, hips and trunk flexibility, we have not practiced hamstrings flexibility ${ }^{18}$.

The second reason could be that the sit-and-reach test is less reliable when it comes to reproducibility and perhaps there has been a false negative steady state. However it is not a decline of flexibility, which would be expected in middle aged people after one year ${ }^{3}$. As a third reason we could not find a minimal detectable and/or a minimal clinically important change in the literature for the two tests; however, there is no change in flexibility in the sit and reach distance, and a decline in the fingertip-to-floor distance in the non-complier group.

One study determined a reliable cutoff point of $4.5 \mathrm{~cm}$ for the fingertip-to-floor distance, and states an improvement of $4.5 \mathrm{~cm}$ or more as an applicable value ${ }^{19}$. In our study there is a mean improvement of $5.31 \mathrm{~cm}$ in the fingertip-to-floor distance.

Our study has limitations, one of which is the absence of a control group. However, as we did not expect performances to improve with another year of aging, participants functioned as their own controls. Because our primary outcome measure was balance, there training content was less guided by the idea of possible flexibility improvement and, therefore, our results may be an 
underestimation. The early withdrawal of five participants could be regarded as a study drawback, but these five still completed follow-up measurements, and are "non-compliers" and not study dropouts. Moreover, based on our sample size estimation for the primary outcome measure, which was a balance parameter, eventual complete study adherence by 17 participants would suffice.

In conclusion, our data suggest that age-adapted Taekwondo training improves lower body flexibility in healthy people over the age of 40 . Our findings concur with the subjective experience that when Taekwondo training programs are more specifically directed at flexibility improvement, improved flexibility will ensue. Although flexibility is a so-called health-related physical function, it is unknown whether improving flexibility results in improved health, but considering flexibility to be conditional for especially lower body motor coordination, independent mobility and a lower risk of falling accidents may result from such improvement. 


\section{References}

1. Kroes G, Greef de M. National initiatives for the promotion of physical activity for older persons in the Netherlands. Journal of Aging and Physical Activity 2000. 8: p. 431-435.

2. Shephard RJ, Berridge M, Montelpare W. On the generality of the "sit and reach" test: an analysis of flexibility data for an aging population. Res Q Exerc Sport., 1990. 61(4): p. 326330.

3. Erkula G, Demirkan F, Kilic BA, Kiter E. Hamstring shortening in healthy adults. . Journal of Back and Musculoskeletal Rehabilitation, 2002. 16: p. 77-81.

4. Mayorga-Vega D, Merino-Marban R, Viciana J. Criterion-Related Validity of Sit-and-Reach Tests for Estimating Hamstring and Lumbar Extensibility: a Meta-Analysis. J Sports Sci Med., 2014. 13(1): p. 1-14.

5. Fong SS, Ng GY. Does Taekwondo training improve physical fitness? Phys Ther Sport., 2011. 12(2): p. 100-106.

6. Cromwell RL, Meyers PM, Meyers PE, Newton RA. Taekwondo: An effective exercise for improving balance and walking ability in older adults J of Gerontol: Medical Sciences., 2007. 62A(6): p. 641-646.

7. Brudnak MA, Dundero D, Van Hecke FM. Are the 'hard' martial arts, such as the Korean martial art, TaeKwon-Do, of benefit to senior citizens? Med Hypotheses., 2002. 59(4): p. 485491.

8. Pons van Dijk G, Leffers P and Lodder J. The Effectiveness of Hard Martial Arts in People over Forty: An Attempted Systematic Review. Societies, 2014. 4(2): p. 161-179.

9. Pons van Dijk G, Leffers P and Lodder J. Feasibility, safety and subjective experience of a oneyear WTF-Taekwondo training course for middle-aged volunteers; the Sekwondo study. Gazz Med Ital-Arch Sci Med 2013. 172(6): p. 433-441.

10. www.novelproduct.com.

11. American College of Sports Medicine. ACSM's resource manual for guidelines for excercise testing and prescriuption. 6th ed. Philadelphia: Lippincott Williams and Wilkins, 2001: p. 5790.

12. Wells KF, Dillon EK. The sit and reach: A test of back and leg flexibility. . Res. Q. for Exerc. Sport. , 1952. 23: p. 115-118.

13. Lemmink KA, Kemper HC, de Greef MH, Rispens $\mathrm{P}$, Stevens M. The validity of the sit-andreach test and the modified sit-and-reach test in middle-aged to older men and women. Res Q Exerc Sport. , 2003. 74(3): p. 331-336.

14. Perret C, Poiraudeau S, Fermanian J, Colau MM, Benhamou MA, Revel M. Validity, reliability, and responsiveness of the fingertip-to-floor test. Arch Phys Med Rehabil. 2001. 82(11): p. 1566-1570.

15. Robinson HS, Mengshoel AM. Assessments of lumbar flexion range of motion: intertester reliability and concurrent validity of 2 commonly used clinical tests. Spine 2014. 39(4): p. 270275. 
16. Chung PK, Yuen CK. Criterion-related validity of sit-and-reach tests in university men in Hong Kong. . Percept Mot Skills., 1999. 88: p. 304-316.

17. Newton R. Validity of the multi-directional reach test: a practical measure for limits of stability in older adults. J Gerontol Med Sci, 2001. 56: p. 248-252.

18. Marcellis RG, Lenssen AF, Elfferich MD, De Vries J, Kassim S, Foerster K, Drent M. Exercise capacity, muscle strength and fatigue in sarcoidosis. Eur Respir J., 2011. 38(3): p. 628-634.

19. Ekedahl H, Jönsson B, Frobell RB. Fingertip-to-floor test and straight leg raising test: validity, responsiveness, and predictive value in patients with acute/subacute low back pain. Arch Phys Med Rehabil. , 2012. 93(12): p. 2210-2215. 


\section{General discussion}

Health-scientific arguments from the SEKWONDO Study for a dedicated, world-wide promotion of Taekwondo training among adult, middle-aged and elderly people.

G. Pons van Dijk and J. Lodder

Published; Adapted version; Taekwondo Journal of Kukkiwon 2015, 13, 179-1991, ISSN 2093-6753 
The lack of sufficient daily exercise among a high proportion of middle-aged and elderly people in especially the Western world has a negative influence on both longevity and quality of life on a societal level ${ }^{1}$. In many countries various types of exercise programs have been recommended to improve this situation, with more or less success. Apart from the question how to motivate middleaged and elderly people to adopt some kind of exercise program into their lives, it is by no means clear what such program should contain. Ideally, a large range of physical functions should be addressed rather than focusing on just one, such as cardio-respiratory function stimulated by jogging, for example. In this connection the concept of general "physical fitness" may be of value. Physical fitness may be seen as the resultant of the combination of various "physical fitness components", such as balance, cardio-respiratory capacity, muscle strength, strength endurance, flexibility, motor coordination, to name a few. Few sports or movement arts contain a large variety of physical fitness components, whereas recommendations for middle-aged and elderly lack those exercises that contain a high degree of motor dynamics, as these are a priori considered to be either impossible or potentially harmful for this age category, but without any data to sustain such idea. However, especially highly dynamical movements and motor complexes may be expected to improve those functions that are required to sustain the ability of executing them in the first place, and which decline especially with age, such as balance and motor coordination.

However, Taekwondo is a Korean hard martial art which addresses a large variety of physical fitness components in its execution, thereby stimulating various health- and skill- related physical fitness components. Potentially, therefore, Taekwondo training qualifies as an ideal and integral method of improving general physical fitness, thereby possibly improving markers of health.

We conducted a review of all studies regarding hard martial arts, like Taekwondo, in middle-aged people on health effect, this did not allow a definite answer to this question, so we performed the SEKWONDO Study, in which 24 volunteers, 12 men and 12 women, varying in age between 40 and 71 , participated in weekly one-hour training sessions for 15 months ${ }^{2-3}$. We aimed to investigate whether Taekwondo as a movement art would both be doable, safe and fun in the older age category, and whether it improves some physical fitness components.

So we proved firstly that Taekwondo training is feasible in middle-aged persons. It was experienced as fun and beneficial, furthermore it has been proven to be safe; 5.7 injuries per 1000 training sessions, compared in other sports with 15-26 adverse events per 1000 training sessions. Although our data indicate that Taekwondo training in middle-aged beginners is possible, safe and fun, we should realize that the sport-didactical approach to this group may differ substantially from that most Taekwondo trainers are used to apply in children, youngsters, and young adults ${ }^{4-5}$. One of them is a dedicated personal approach. Furthermore, as the ability to execute certain movement patterns, their intensity and duration varies largely between individuals, one should allow a considerable degree of freedom in these between participants, rather than applying strict limits to all of them similarly. Furthermore, we abided by two more didactical principles: we aimed to maintain a wellbalanced relation between personal capacity (level of skill) and demand from outside (exercise 
difficulty), to avoid feelings of incompetence by disproportionate demands on the one hand, and boredom when demands are below their capacity on the other ${ }^{6}$. Another principle was that our teaching was cognitive rather than visual: although we exemplified the various movements by demonstrating them, verbal instructions and explanations were stratified in time as well as in degree of difficulty, detailed, and repetitive. Sport-didactical experience gained during the study are published elsewhere ${ }^{7}$.

Our main outcome measure, balance, improved significantly in various aspects; there was a shift towards more intensive use of forward control in balance maintenance, as do younger people ${ }^{8}$. Younger people use the forefoot's muscle activity for maintenance of balance more than elderly do. As forward sway to maintain balance in man is twice as large as backward sway ( $8^{\circ}$ versus $4^{\circ}$ ), this may explain why elderly are more prone to fall, and when they do it is often backwards ${ }^{8}$. This improvement of forward balance control likely resulted from practicing the typical Taekwondo stances, and the footwork in the various Taekwondo exercises. Such movements require the center of gravity to be balanced by mainly forefoot function ${ }^{9}$. Together with improvement in a number of other balance parameters, our findings suggest that age-adapted Taekwondo training may eventually lower the chance of falls in the elderly. A point of interest is that balance improved despite any measurable improvement of leg musculature strength. This indicates that in the presence of regular muscular strength, trying to strengthen the leg musculature will only marginally, if any, contribute to balance improvement. Rather, balance is better trained by the execution of complex movements, combined with a certain degree of motor dynamics, such as poomsae and Taekwondo sparring exercise training, which both contain strong elements of static and dynamic balance maintenance. Most of our volunteers already performed physical exercises of some sort, which in some took even many hours weekly, whereas we found no association, either positive or negative, with the level of their current physical activity. This indicates that Taekwondo practice can be added to most kinds of physical exercise people already are involved in, without losing its efficacy.

Also several aspects of cognition improved, especially cognitive speed in relation to inhibition and information processing ${ }^{10}$. In Taekwondo sparring, motor speed and technique are important elements. Our training program contained various sparring-related techniques which required controlled motor speed and reflex motor reaction time, visuo-motor coordination, as well as timely inhibition of movements, although genuine Taekwondo (contact) sparring was never practiced during our study. Such exercises may, therefore, contribute to improve the cognitive elements required for the execution of these movements. As we found no change in cardiac function, our findings suggest that exercise-related improvement of cognitive functions do not invariably depend on cardio-aerobic improvement. Improved cognitive functions in our study may rather have resulted from the training of complex motor patterns inherent to Taekwondo, especially during Poomsae. The participants practiced three different Poomsaes (this is a difficult style-figure named Taegeuks 1, 2, and 3), which demanded memory training for complex motor sequences, as well as mental concentration and attention. It seems only logical to hypothesize that the more complex movement patterns are, the more higher cerebral functions become involved. Consequently, movement arts such as Taekwondo 
may offer more benefit than sports involving mere repetition of movement patterns of lesser complexity such as walking, jogging, or cycling. Training of sparring-related movements probably contributed to cognitive improvement due to their time-related dynamics.

In addition to this, motor coordination is a skill-related component of physical fitness, and has to do with correct and efficient execution of complex motor patterns. However, not only does this concept escape clear definition (we found numerous definitions in the literature), but also, because of its complexity, there is no generally accepted and validated way how either to qualify or quantify it. Yet, from experience we know that motor coordination deteriorates with age, and mitigating its agedependent decline would be desirable. However, the question is how to measure it. Various aspects has been implicated as belonging to the domain of motor coordination: high-level hierarchy of motor control, involving high-order brain structures and functions; proper temporal and spatial control of movement, allowing dedicated goal direction; complicated feed-back and feed-forward mechanisms of agonist and antagonist muscles and muscle groups ${ }^{11}$. Taekwondo offers one solution, which is the qualitative judgment of poomsae performance. Although such judgment is in fact an expert opinion, its validity may be high enough to establish an decrease or increase in the quality of its performance, which can be taken as reflecting the quality of motor coordination. We intended to teach our volunteers the first Taegeuk during the one-year course as a practice of motor coordination. However, we ended up by having taught them the second Taegeuk as well, because they manage to perform the first Taegeuk at a satisfactory level much earlier than expected. During the final stage of the project they started on the third Taegeuk. When they started on the second Taegeuk, they asked the trainers why they had started with number one, and not with number two, as the second was experienced as so much easier than the first one. Obviously, not only the performance of complex movement patterns had improved, but also their capacity to learn new motor complexes had been enhanced. As Taekwondo Poomsae contains most elements that are part of coordination control, we suggest that Taekwondo Poomsae training offers a cheap, doable, safe, and amusing opportunity to improve overall motor coordination, while mitigating the effects of aging on this function.

There was furthermore an improvement of flexibility in spine and pelvis and in a lesser extent of the hamstrings.

This is the first study in which the health benefits of a hard martial art training was investigated in a group of middle-aged volunteers for over a period of one year with an age-adapted training program.

However, our study has some drawbacks. The most important one is the absence of a control group. The different health aspects we tested were described extensively in literature to decrease with every year of increasing in age. Because the only parameter which altered was the Taekwondo training we decide the participants could function as their own control. Also our study group was not a sedentary population. The participants had other physical activities which, however, did not really change during that year. Therefore, we attribute changes to the intervention rather than to the unchanged pattern of other physical activities. 
Another limitation concerns extrapolating our results to people over forty in general, since although the study population was larger than in other studies ${ }^{4-5,12}$ our sample was still rather small, and while furthermore the education level of our group on average was high.

The early withdrawal of five participants could also be regarded as a study drawback, but they completed follow-up measurements, and thus are non-compliers instead of study dropouts. Moreover, our sample size estimation for the primary outcome measure, was 17 persons.

Other studies on this topic showed that exercise programs, including those based on martial arts, lower the chance of a number of negative consequences of aging ${ }^{4}$. Physical activity and sports which are mainly focused on the training of the proprioceptive system (balance sports like Tai Chi and Yoga) are effective in improving balance and in reducing the prevalence of falls in the elderly ${ }^{13}$. Such sports are clearly better to improve balance function than sports that aim to improve cardiovascular function (bioenergetic sports, such as running) ${ }^{14}$.

A review of 23 studies on effects on some physical functions of Taekwondo training suggested benefits on aerobic capacity, body composition and flexibility. However, that descriptive review considered no age specification ${ }^{15}$.

Future research can be improved by as stated above, using a control group and thus a randomized control trial. With the increase of elderly people there is an exponential increase of medical costs due to fall incidents, but also due to cognitive problems and thus the necessity of day cares et cetera. Taekwondo-based exercising could be a good solution and a way to mitigate age-related balance and cognitive decline. This could be a cheap, safe and even enjoyable solution. In most countries there is already an existing training infra-structure. And as we experienced, with minor adaptations an age adapted Taekwondo training can be offered ${ }^{7}$.

\section{Conclusion}

Even within the restrictions of some drawbacks mentioned above of our SEKWONDO Study our data indicate that Taekwondo training should be considered as a serious possibility for middle-aged and elderly persons as a safe and enjoyable movement art, that may not only improve subjective physical and mental wellbeing, but also a number of important physical and mental functions that tend to deteriorate with age. Therefore, Taekwondo training may qualify as one of the most adequate exercise systems to stimulate and maintain a large variety of physical and mental functions, and mitigate both age-related cognitive and physical decline, while being cheap, safe, and enjoyable. The practice does not require exhaustive training intensity to achieve results. Promotion of Taekwondo among adult, middle-aged or elderly beginners does not require the creation of an expensive or complicated infra-structure: the infra-structure is already there, consisting of the many Taekwondo clubs in most countries in the world. Moreover, there are regional, national and continental dedicated Taekwondo organizations, which are facilitated by the World-wide operating Korean 
of Kukkiwon and the World Taekwondo Federation. So why remains the participation of people above the adult age so low? An important reason may be the restricted, and therefore false, image most adults maintain about Taekwondo, as an aggressive fighting sport for youngsters. In our view, this should change, and such change should at least be endorsed by the various Taekwondo organizational bodies. Any fear that associating Taekwondo with increasing age would carry negative overtones, would be completely unjustified; the popularity of Para-Taekwondo, and how this has strengthened the image of Taekwondo world-wide may serve as an example. The art has only to benefit when substantial numbers of members would join the organization. Similarly, any bias on the side of Taekwondo trainers or club boards should be addressed and changed where possible. At least these should be made aware of this new potential of the art. Community and governmental services devoted to improvement of general health should also be informed about the benefits of Taekwondo practice by adults and elderly, so they may facilitate its availability and training quality for the intended age group. Especially these organizations may be convinced as the costs involved are extremely low compared to other measured aiming at similar effects.

As one swallow does not make a summer; additional studies are required to ascertain effects of Taekwondo training beyond any doubt. Most of our participants had a rather high education level, and most of them were already physically active in other ways. Therefore, further study is warranted to see whether extrapolating our results to other types of middle-aged people is justified. More differentiation is required as to age and gender dependency of such effects, and other factors may be thought of. Also, more detailed information on if and how specific training modalities may improve specific fitness components would be useful; for example: if specific power training exercises would be added, would these really not influence muscle power? One would suspect they would.

The time that Taekwondo is merely considered as a "competitive fighting sport" seems long overdue, and practically, about eighty percent of Taekwondo practitioners are never involved in competition; they practice Taekwondo as a movement art, more aiming at harmonizing body and mind as the classical martial arts intended. Current evidence suggest that now it is time to popularize the art also more intensively amongst all age groups, which in our view, is best been performed by the currently available organizational structure, and in a top-down approach. 


\section{References}

1. Lobstein $\mathrm{T}$, Rigby $\mathrm{N}$, Leach $\mathrm{R}$. EU Platform on diet, physical activity and health. http://ec.europa.eu/health/ph determinants/life style/nutrition/documents/iotf en.pdf. 2005.

2. Philips LH. Sports injury incidence. Br J Sports Med 200. 34: p. 133-136.

3. Pons van Dijk G, Leffers P and Lodder J. The Effectiveness of Hard Martial Arts in People over Forty: An Attempted Systematic Review. Societies, 2014. 4(2): p. 161-179.

4. Cromwell RL, Meyers PM, Meyers PE, Newton RA. Taekwondo: An effective exercise for improving balance and walking ability in older adults J of Gerontol: Medical Sciences., 2007. 62A(6): p. 641-646.

5. Brudnak MA, Dundero D, Van Hecke FM. Are the 'hard' martial arts, such as the Korean martial art, TaeKwon-Do, of benefit to senior citizens? Med Hypotheses., 2002. 59(4): p. 485491.

6. Csikszentmihalyi M. Flow: The Psychology of Optimal Experience. Harper Perennial Publications; 1991.

7. Lodder J. Sekwondo. World Taekwondo Federation Taekwondo Initiation for Novices Over the Age of Forty. A Didactical Guide for Trainers and Students. . Strategic Book Publishing and Rights Co. , 2012. Houston, USA.

8. Tanaka $\mathrm{T}$, Takeda $\mathrm{H}$, Izumi $\mathrm{T}$, Ino S, Ifukube T. Effects on the location of the centre of gravity and the foot pressure contribution to standing balance associated with ageing. Ergonomics. 1999. 42(7): p. 997-1010.

9. Leong HT, Fu SN, Ng GY, Tsang WW. Low-level Taekwondo practitioners have better somatosensory organisation in standing balance than sedentary people. Eur J Appl Physiol. 2011. 111(8): p. 1787-1793.

10. Pons van Dijk G, Huyts M, Lodder J. Cognition improvement in Taekwondo novices over 40. Results from the SEKWONDO Study . Frontiers in Aging Neuroscience, 2013.

11. U.S. Department of Health and Human Services. Physical Activity and Health: A Report of the Surgeon General. Department of Health and Human Services, Centers for Disease Control and Prevention, National Center for Chronic Disease Prevention and Health Promotion, 1996. Atlanta, GA: U.S.

12. Douris $\mathrm{P}$, Chinan A, Gomez M, Aw A, Steffens D, Weiss S. Fitness levels of middle aged martial art practicioners. Br J Sports Med, 2004. 38: p. 143-147.

13. Rubenstein LZ, JosephsonKR. The epidemiology of falls and syncope. Clin Geriatr Med. , 2002. 18: p. 141-158.

14. Gauchard GC, Gagloff P, Jeandel C, Perrin PP. Influence of regular proprioceptive and bioenergetic physical activities on balance control in elderly women. J Gerontol A Biol Sci Med Sci., 2003. 58(9): p. 846-850.

15. Fong SS, Ng GY. Does Taekwondo training improve physical fitness? Phys Ther Sport., 2011. 12(2): p. 100-106. 
8

Summary 
In the Netherlands, about $25 \%$ of all people lack sufficient daily physical activity, and about $10 \%$ do not exercise at all. A low level of regular physical exercise increases the risk of cardiovascular disease, diabetes mellitus, and osteoporosis, whereas it has a negative impact on mood, cognitive functions, mobility, and overall wellbeing. With increasing age these negative consequences lead to deterioration of mobility, jeopardizing self-maintenance and increase the chance of dependency on others.

Several aspects of physical fitness components decrease during aging, such as balance, cardiorespiratory capacity, muscle strength, strength endurance, flexibility, motor coordination, to name a few. Exercise programs, including those based on martial arts, have been proved to lower the chance of a number of negative consequences of aging. However few sports or movement arts contain a large variety of physical fitness components, whereas recommendations for middle-aged and elderly lack those exercises that contain a high degree of motor dynamics, as these are a priori considered to be either impossible or potentially harmful for this age category, but without any data to sustain such idea. Moreover, especially highly dynamical movements and motor complexes may be expected to improve those functions that are required to sustain the ability of executing them in the first place, and which decline especially with age, such as balance and motor coordination.

Taekwondo, a Korean hard martial art, addresses a large variety of physical fitness components in its execution, thereby stimulating various health- and skillrelated physical fitness components. Potentially, therefore, Taekwondo training qualifies as an ideal and integral method of improving general physical fitness, thereby possibly improving markers of health.

Therefore, we performed a study in seniors to measure the feasibility of such training program and the effects of Taekwondo training on balance, cognition, muscle strength, physical fitness and flexibility.

In Chapter 1 an introduction, including background information of our study is presented.

We conducted a literary search on the effect of hard martial arts on several physical fitness components such as balance, flexibility, gait, strength, cardiorespiratory function and several mental functions in people over forty. A computerized literature search was carried out.

Studies were selected when they had an experimental design, the age of the study population was over 40 years of age, one of the interventions was a hard martial art, and when at least balance and cardiorespiratory functions were used as an outcome measure.

We included four studies, with, in total, 112 participants, aged between 51 and 93 years. The intervention consisted of Taekwondo or Karate. Total training duration varied from 17 to 234 hours.

All four studies reported beneficial effects, such as improvement in balance, in reaction tests, and in duration of single leg stance. We conclude that because of serious methodological shortcomings in all four studies, currently there is suggestive, but insufficient evidence, that hard martial arts practice improves physical fitness functions in healthy people over 40 . However, considering the importance of such effects, and the low costs of the intervention, the potential of beneficial health effects of ageadapted, hard martial arts training, in people over 40 , warrants further study. 
In Chapter $\mathbf{2}$ we investigated in middle-aged healthy volunteers the feasibility, safety, and subjective experience of age-adapted Taekwondo training of one hour a week during one year.

We used the same method in all the following chapters, consisting of a single arm intervention study with each participant serving as his or her own control. Our study population consisted of 24 healthy volunteers, ranging in age from 40 to 71 years of age. All participants were tested in the month before the start of the study, and as soon as possible after the last training session.

A questionnaire on the participants' subjective assessment on various aspects of the program was filled out three months after study onset, and at its end.

As a measure of program feasibility, we counted study dropouts and program non-compliers, and registered the reasons for withdrawal. To describe safety we measured and listed all training related injuries. Subjective assessment of training effects by participants was carried out by means of a questionnaire.

In total five participants withdrew from the training program, but all 24 had baseline and final measurements; three withdrew because of the program content and the complexity of the Taekwondo exercises.

We offered 60 sessions and allowed additional training at the trainers' Taekwondo club. The 19 participants who completed the study followed a median of 39 training sessions (range: 25-67). There were five (non-serious) training related injuries, which equals 5.7 per 1000 athlete exposures (AE) (confidence interval: 4-8/1000).

Subjective benefits in the 19 study completers were on: physical fitness (9), mental fitness (5), selfconfidence (6), and mood (4). Eighteen participants adhered to the program because it was experienced as fun even though two of these reported persistent minor ailments as a consequence of training.

We conclude that long-term age-adapted Taekwondo training is feasible in middle-aged, healthy persons. It can be safely executed, whereas it is experienced as fun and subjectively judged beneficial by most. Age-adjusted Taekwondo should be listed among the sports from which middle-aged people can choose to increase their physical exercise.

In Chapter $\mathbf{3}$ we studied the effect of one year Taekwondo training on several aspects of balance. Balance deteriorates with age, and may eventually lead to falling accidents which may threaten independent living. As Taekwondo contains various highly dynamic movement patterns, Taekwondo practice may sustain or improve balance. Therefore, we investigated the effects of age-adapted of weekly one hour Taekwondo training during one year on various balance parameters, such as: motor orientation ability (primary outcome measure), postural and static balance test, single leg stance, one leg hop test, and a questionnaire.

Motor orientation ability significantly increased in favor of the antero-posterior direction with a difference of 0.62 degrees towards anterior compared to pre-training measurement, when participants corrected the tilted platform rather towards the posterior direction; female gender being an independent outcome predictor. On postural balance measurements sway path improved in all 19 participants, with a median of $9.3 \mathrm{~mm} / \mathrm{sec}$ (range 0.71-45.86), and sway area in 15 participants 
with $4.2 \mathrm{~mm}^{2} / \mathrm{sec}$ (range 17.39-1.22). Static balance improved with an average of 5.34 seconds for the right leg, and with almost 4 seconds for the left. Median single leg stance duration increased in 17 participants with 5 seconds (range 1-16), and in 13 participants with 8 seconds (range 1-18). The average one leg hop test distance increased (not statistically significant) with $9.5 \mathrm{~cm}$. The questionnaire reported a better 'ability to maintain balance' in sixteen.

In conclusion, our data suggest that age-adapted Taekwondo training improves various aspects of balance control in healthy people over the age of forty.

Chapter 4 relates about the effect of Taekwondo training on several aspects of cognition. Age-related cognitive decline is associated with increased risk of disability, dementia and death. Recent studies suggest improvement in cognitive speed, attention and executive functioning with physical activity. However, whether such improvements are activity specific is unclear.

Therefore, we aimed to study the effect of one year age-adapted Taekwondo training on several cognitive functions, including reaction/ motor time, information processing speed, and working and executive memory, in 24 healthy volunteers over forty.

Reaction and motor time decreased with 41.2 seconds and 18.4 seconds ( $p=0.004, p=0.015)$, respectively. Digit symbol coding task improved with a mean of 3.7 digits $(p=0.017)$. Digit span, letter fluency, and trail making test task-completion-time all improved, but not statistically significant. The questionnaire reported "better" reaction time in 10 and "unchanged" in 9 of the nineteen study compliers.

In conclusion, our data suggest that age-adapted Taekwondo training improves various aspects of cognitive function in people over 40 , which may, therefore, offer a cheap, safe and enjoyable way to mitigate age-related cognitive decline.

In Chapter 5 we studied the effects of age-adapted Taekwondo training of one hour a week, during one year, in 24 healthy middle-aged volunteers on hamstrings and quadriceps strength, treadmill run, including in units of metabolic equivalents (MET), six minute walking test, a running test, and a questionnaire.

There was no significant improvement in muscle strength nor in cardio fitness, but neither was there a decline as expected with one year age increase. A questionnaire showed a subjective improvement in 30-50 percent of the compliers, and no change in the non-complier group.

In conclusion, our data at least suggest that age-adapted Taekwondo training may stabilize cardiorespiratory physical fitness and muscle strength in healthy people over the age of 40 .

In Chapter 6 we discuss flexibility, one of the components of physical fitness in middle-aged and senior adults, which is of importance for executing and sustaining motor activities in daily life. Flexibility declines with age, starting at approximately 40 years. A decrease of flexibility may also affect gait and lead to an increased risk of falls, whereas it may also increase the susceptibility to musculoskeletal injuries.

One of the main components of Taekwondo consists in the performance of high kicks, which are full range movements at high speed, requiring a high degree of flexibility for skillful performance. In this 
study we sought to investigate whether age-adapted Taekwondo training of one hour a week during one year, improves flexibility in people over 40 , measured using a sit and reach flexibility box and by measuring fingertip-to-floor distance.

This study shows a trend of improvement in spine and pelvis flexibility in healthy volunteers over 40 . We observed a (statistically significant) improvement in the fingertip-to-floor distance, but no change in the sit and reach flexibility test. More than $50 \%$ of the compliers experienced an improvement in flexibility, while none of them reported a deterioration. The non-compliers reported no changes.

In conclusion, our data suggest that age-adapted Taekwondo training improves lower body flexibility in healthy people over the age of 40 . Our findings concur with the subjective experience that when Taekwondo training programs are more specifically directed at flexibility improvement, improved flexibility will ensue.

In Chapter $\mathbf{7}$ we made a short summary of this thesis and further suggest how "Sekwondo" may be implemented considering the currently existing infra-structure of Taekwondo training possibilities. Because of the potential of substantial health gain on a societal level, we conclude that Taekwondo practice amongst adult, middle-aged and elderly beginners should be stimulated worldwide. The worldwide existing infra-structure as currently endorsed by Kukkiwon may well serve such activity. 
9

Samenvatting 
In Nederland, heeft circa $25 \%$ van de bevolking onvoldoende dagelijkse lichaamsbeweging en circa $10 \%$ sport zelfs helemaal niet. Te weinig regelmatig fysiek inspannen verhoogt de kans op cardiovasculaire ziektes, diabetes mellitus en osteoporose, en daarbij heeft het ook een negatief effect op de stemming, cognitieve functies, mobiliteit en algeheel welbevinden. Met het toenemen van de leeftijd, leiden deze negatieve consequenties tot een achteruitgang van mobiliteit, waardoor de zelfstandigheid in het gedrang komt en de kans op afhankelijkheid van anderen verhoogt.

Meerdere aspecten van fysieke gesteldheid verslechteren bij het ouder worden, zoals bijvoorbeeld balans, spierkracht, uithoudingsvermogen, flexibiliteit en motore coördinatie.

Van sportprogramma's, gebaseerd op vechtsporten, is bewezen dat ze de kans op meerdere negatieve consequenties van het ouder worden, verlagen. Echter maar weinig sporten of sportoefeningen bevatten een grote verscheidenheid van de verschillende fysieke componenten zoals hierboven beschreven. Hierbij is het ook nog zo dat de meeste sportoefeningen voor mensen van de middelbare leeftijd en ouderen geen oefeningen bevatten met een hoge mate van motore dynamiek, aangezien tevoren gedacht wordt dat deze niet mogelijk of zelf schadelijk zijn voor deze leeftijdscategorie, dit echter zonder enkele data om deze gedachte te ondersteunen. Bovendien wordt met name van zeer dynamische bewegingen en motore complexen verwacht dat ze de functies verbeteren die nodig zijn om deze te blijven uitvoeren in de eerste plaats en deze nemen ook af bij het ouder worden, zoals bijvoorbeeld balans en motore coördinatie.

Taekwondo, een Koreaanse hard martial art (harde gevechtssport), bestaat uit een grote verscheidenheid van deze fysieke componenten, hierdoor stimuleer je verschillende gezondheids- en niveau-afhankelijke fysieke componenten. Mogelijk dat Taekwondotraining hierdoor een ideale en integrale methode voor het verbeteren van de algehele fysieke gesteldheid is, en daardoor mogelijk ook gezondheidsmarkers verbetert.

Hierom hebben we een studie in senioren verricht, om de haalbaarheid van een dergelijk trainingsprogramma te bekijken, als ook de effecten van Taekwondotraining op balans, cognitie, spierkracht, conditie en flexibiliteit.

In Hoofdstuk 1 wordt een introductie met achtergrondinformatie over onze studie behandeld. We hebben een literatuuronderzoek naar het effect van harde gevechtssporten op verschillende fysieke gesteldheid componenten verricht, zoals balans, flexibiliteit, gang(spoor), cardiorespiratoire functie en meerdere mentale functies in mensen van 40 jaar of ouder. Een geautomatiseerd literatuuronderzoek werd uitgevoerd.

Studies die geïncludeerd werden hadden de volgende inclusiecriteria: een experimentele opzet, een leeftijd van de studiepopulatie van 40 jaar of ouder, een van de interventies betrof een harde gevechtssport en met als uitkomstmaat in ieder geval balans of cardiorespiratoire functies.

We hebben 4 studies geïncludeerd, met in totaal 112 deelnemers, met een leeftijd tussen de 51 en 93 jaar oud. De interventie bestond uit Taekwondo of Karate. De totale trainingsduur wisselde tussen de 17 en 234 uur. Elk van deze studies beschreef meerdere gunstige effecten, zoals verbetering in balans, reactietesten en in een langere duur van de monopedaal stand (het staan op één been). Onze conclusie is dat er door ernstige methodologische tekortkomingen in alle vier de studies, op dit 
moment suggestief maar niet overtuigend bewijs is, dat het beofenen van een harde gevechtssport door gezonde 40-plussers fysieke gesteldheid functies verbeteren. Echter, gezien de betekenis van zulke effecten, met daarbij de lage kosten van de interventie in acht nemend, is verder onderzoek naar de mogelijkheden van de positieve gezondheidseffecten van leeftijd-geadapteerde, training in harde gevechtssport bij mensen boven de 40 jaar zeker nodig.

In Hoofdstuk 2 onderzoeken we of leeftijd-geadapteerde Taekwondotraining bestaand uit 1 uur per week gedurende één jaar, in middelbare gezonde vrijwilligers, mogelijk en veilig is en daarbij bekijken we de subjectieve ervaring van de deelnemers.

We gebruikten dezelfde methode als in de volgende hoofdstukken, bestaande uit een enkele arm interventiestudie waarbij elke deelnemer als eigen controle fungeerde. Onze studiepopulatie bestond uit 24 gezonde vrijwilligers, met een leeftijd van 40 tot 71 jaar. Alle deelnemers werden in de maand voor de start van de studie gemeten en zo snel mogelijk na de laatste trainingssessie. Een vragenlijst over de deelnemers' subjectieve beoordeling van verschillende aspecten van het programma werd 3 maanden na start van de studie en aan het einde afgenomen.

Als een maat van haalbaarheid van het programma bekeken we de studieafvallers (non-compliers) en registreerden we de reden van terugtrekking. Om veiligheid te beschrijven, maten we en bestudeerden we alle training-gerelateerde letsels. Subjectieve beoordeling van de effecten van de training door de deelnemers werd onderzocht middels een vragenlijst.

In totaal stopten er 5 deelnemers met het trainingsprogramma, echter alle 24 deelnemers hebben alle voor- en nametingen ondergaan; drie stopten wegens de inhoud van het programma en de complexiteit van de Taekwondo-oefeningen.

We hebben 60 trainingssessies gegeven en men kon nog additionele training bij de trainers Taekwondoclub volgen. De 19 deelnemers die de studie hebben afgemaakt volgden een mediaan van 39 trainingssessies (radius: 25-67). Er waren vijf (niet ernstige) training-gerelateerde letsels, dit komt overeen met 5,7 per 1000 athlete exposures (atleet blootstellingen) (betrouwbaarheidsinterval: $4,8 / 1000)$.

Subjectieve verbetering van de 19 deelnemers die de studie afmaakten waren: fysieke fitheid (9), mentale fitheid (5), zelfvertrouwen (6) en stemming (4). Achttien deelnemers bleven deelnemen aan het programma omdat ze het leuk vonden, dit alhoewel twee van hen kleine kwaaltjes ervoeren door de training.

Wij concluderen dat langdurige leeftijd-geadapteerde Taekwondotraining haalbaar is in middelbare gezonde personen. Het kan veilig uitgevoerd worden en wordt ervaren als leuk met subjectieve verbetering op meerdere niveaus door de meeste deelnemers. Leeftijd-geadapteerde Taekwondo zou gemeld moeten staan tussen de sporten waaruit mensen van middelbare leeftijd kunnen kiezen om meer lichaamsbeweging te krijgen.

In Hoofdstuk 3 onderzochten we het effect van een jaar Taekwondotraining op meerdere aspecten van balans. Balans verslechtert naarmate we ouder worden en kan uiteindelijk tot valincidenten leiden, waardoor zelfstandig wonen bedreigd kan worden. Aangezien Taekwondo bestaat uit zeer 
dynamische bewegingspatronen, zou Taekwondotraining balans gelijk houden dan wel verbeteren. Hierom onderzochten we de effecten van leeftijd-geadapteerde Taekwondotraining, één uur per week, gedurende één jaar op verschillende balansparameters, zoals: motor orientation ability (motore oriëntatie) (primaire uitkomstmaat), houdings- en statische balans test, monopedaalstand, one leg hop test (een been hop test) en een vragenlijst.

Motor orientation ability verbeterde significant met een correctie naar de voor achterwaartse richting, met een verschil van 0,62 graden in voorwaartse richting, dit in vergelijking met de voormetingen waarbij de deelnemers het gekantelde platform in achterwaartse richting corrigeerden; met hierbij het vrouwelijk geslacht als onafhankelijke uitkomstvoorspeller. In posturele balansmetingen verbeterde de sway path (zwaai pad) in alle 19 deelnemers, met een mediaan van $9,3 \mathrm{~mm} / \mathrm{sec}$ (radius 0,71-45,86) en sway area (zwaai gebied) verbeterde in 15 deelnemers met 4,2 $\mathrm{mm}^{2} / \mathrm{sec}$ (radius 17.39-1.22). Statische balans verbeterde met een gemiddelde van 5,34 secondes voor het rechter been en met bijna 4 secondes voor het linker been. De mediane monopedaal stand duur verlengde in 17 deelnemers met 5 secondes (radius 1-16) en in 13 deelnemers met 8 secondes (radius 1-18). De gemiddelde one leg hop test afstand verlengde (niet statistisch significant) met 9,5 $\mathrm{cm}$. De vragenlijst toonde een betere 'mogelijkheid tot balans houden' in 16 deelnemers.

Concluderend, geeft onze data aan dat leeftijd-geadapteerde Taekwondotraining meerdere aspecten van balanscontrole in gezonde 40-plussers verbetert.

Hoofdstuk 4 gaat over het effect van Taekwondotraining op meerdere aspecten van cognitie. Leeftijd-gerelateerde cognitieve achteruitgang is geassocieerd met een verhoogd risico op onbekwaamheid, dementie en overlijden. Recente studies lijken een verbetering in cognitieve snelheid, aandacht en executieve functies te laten zien door lichamelijke activiteit. Het is echter onduidelijk of deze verbeteringen activiteit specifiek zijn.

Hierom was ons doel om het effect van een jaar lang leeftijd-geadapteerde Taekwondotraining te bestuderen op het gebied van verschillende cognitieve functies, waaronder reactie- en motortijd, informatieverwerking snelheid en het werk- en executieve geheugen, in 24 gezonde 40 -plussers.

Reactie- en motortijd verminderde met 41,2 secondes en 18,4 secondes ( $p=0,004$ en $p=0,015$ ) respectievelijk. De cijfersymbool-codeertaak verbeterde met een gemiddelde van 3,7 cijfers $(p=0,017)$. Digit span (cijferreeks), letter fluency (letter vlotheid) en trail making test (letter- en cijfer verbind test) verbeterden, echter niet statistisch significant. De vragenlijst toonde een "betere" reactietijd in 10 deelnemers en "onveranderd" in 9 van de 19 deelnemers.

Concluderend, suggereren onze data dat leeftijd-geadapteerde Taekwondotraining verschillende cognitieve functies verbetert in mensen boven de 40 jaar, hierom kan dit een goedkope, veilige en leuke manier zijn om leeftijdsafhankelijke cognitieve achteruitgang tegen te gaan.

In Hoofdstuk 5 bestudeerden we de effecten van leeftijd-gerelateerde Taekwondotraining van 1 uur per week, gedurende één jaar, in gezonde middelbare vrijwilligers op hamstrings- en quadricepskracht, hardlopen op de loopband, hierbij ook units of metabolic equivalents (MET; eenheden van metabole equivalenten), zes minuten looptest, een hardlooptest en een vragenlijst. 
Er was geen significante verbetering in spierkracht en in cardiale fitheid, er was echter ook geen verslechtering zoals verwacht bij een jaar ouder worden. De vragenlijst toonde een subjectieve verbetering in 30-50\% van de compliers (deelnemers die het hele jaar hebben meegedaan) en geen verandering in de non-complier groep.

Concluderend geeft onze data aan dat leeftijd-geadapteerde Taekwondotraining de cardiorespiratoire fysieke fitheid en sperkracht in gezonde mensen boven de 40 jaar stabiliseert.

In Hoofdstuk 6 bekijken we flexibiliteit, een van de componenten van fysieke fitheid in middelbare en oudere volwassenen, welke belangrijk is voor het uitvoeren en onderhouden van motore activiteiten in het dagelijkse leven. Flexibiliteit neemt af naarmate we ouder worden, beginnend vanaf de leeftijd van ongeveer 40 jaar. Een afname van flexibiliteit kan ook de gang beïnvloeden en leiden tot een verhoogd valrisico, met daarbij ook een verhoogde kans op letsels van het bewegingsapparaat.

Een van de hoofdcomponenten van Taekwondo bestaat uit het uitvoeren van hoge schoppen, dit zijn volledig circulaire bewegingen met hoge snelheid, waarvoor je ter uitvoering een hoge mate van flexibiliteit nodig hebt. In deze studie onderzochten we of leeftijd-geadapteerde Taekwondotraining van 1 uur per week gedurende een jaar, de flexibiliteit in 40-plussers verbetert, met als maten zit- en reik flexibiliteit en de vingertop tot vloer afstand.

Deze studie toont een trend van verbetering in wervel- en bekkenflexibiliteit in gezonde vrijwilligers boven de 40 jaar. We observeerden een (statistisch significante) verbetering in de vingertop tot vloer afstand, maar geen verandering in de zit en reik flexibiliteit test. Meer dan $50 \%$ van de compliers bemerkte een verbetering in flexibiliteit, en geen van hen rapporteerde een achteruitgang. De noncompliers bemerkten geen veranderingen.

Concluderend, lijkt onze data te zeggen dat leeftijd-geadapteerde Taekwondotraining de onderlichaamflexibiliteit verbetert in gezonde mensen boven de 40 . Onze bevindingen passen bij de subjectieve belevenis dat wanneer Taekwondo trainingsprogramma's meer specifiek gericht zijn of verbetering van flexibiliteit, deze ook zal verbeteren.

In Hoofdstuk $\mathbf{7}$ hebben we een korte samenvatting van dit proefschrift gemaakt en bespreken we verder hoe "Sekwondo" in de huidige infrastructuur van Taekwondotraining geïmplementeerd kan worden. Gezien de potentiele duidelijke gezondheidswinst op maatschappelijk niveau, concluderen we dat Taekwondobeoefening in volwassen, middelbare en oudere beginners wereldwijd gestimuleerd zou moeten worden. De reeds bestaande wereldwijde infrastructuur, ondersteund door Kukkiwon, zou zo een activiteit goed kunnen ondersteunen. 


\section{0}

Valorisatie 
Inleiding

In onze huidige maatschappij wordt het 'waarom' steeds belangrijker, zo ook in het uitvoeren van wetenschappelijk onderzoek. Hoe gemakkelijk het vroeger was om een omstreden onderzoek op te starten, hoe moeilijk het nu is om enig onderzoek op te starten.

Hierdoor eindigt het promotietraject niet alleen met de mooie term 'valorisatie' maar het is hier ook mee begonnen. De eerste stap tot dit boekje was namelijk het maken van een protocol ter beoordeling van de Medische Ethische Commissie, of zoals mooi afgekort het MEC.

Deze eerste en zeer uitgebreide stap laat je eigenlijk al meteen nadenken over de valorisatie in de breedste zin van het woord. Een van de eerste twee onderwerpen is dan ook de lasten en risico's die het onderzoek voor de mogelijke deelnemers zal brengen. In dit protocol hebben we dan ook tot in detail besproken hoeveel tijd een deelnemer voor elke afzonderlijke keuring voor de start van ons onderzoek kwijt zal zijn, wat de risico's van de betreffende keuring is, welke testen ze moeten doormaken, hoe lang dit zal duren en ga zo maar door.

Daarnaast hebben we uiteraard ook uitgebreid besproken wat het voordeel is voor de deelnemers en hopelijk ook voor andere mensen in de toekomst. Ook door het hele proefschrift heen wordt dit meerdere keren genoemd. In dit hoofdstuk, zal dit alles naar aanleiding van 5 opgestelde vragen nog eens uitgebreid besproken worden.

\section{Relevantie}

Wat is de maatschappelijk (en/of economische) relevantie van de onderzoekresultaten?

Zoals bekend is er na de tweede wereldoorlog een zogenoemde babyboom geweest. Dit houdt in dat er rond de jaren 50 van de vorige eeuw, toen de economische tijden weer verbeterden, in verhouding zeer veel baby's geboren zijn. Deze generatie bereikt nu de pensioengerechtigde leeftijd en komt dus in de leeftijd 65-plus. Dit proces wordt ook wel de vergijzing van de maatschappij genoemd. Hierdoor krijg je plots een grote groep ouderen die niet meer bijdragen in de financiën en daar boven op ook nog de kans hebben op hoge kosten in de gezondheidzorg.

Eén van de belangrijkste redenen van acute opnames in het ziekenhuis bij ouderen is helaas nog 
steeds valincidenten, uiteenlopend van een klein trauma tot een gebroken heup met een operatie, langdurige opname en uiteindelijk ook langdurig revalideren als gevolg. Zoals ik reeds in dit proefschrift beschreven heb, is balans of evenwicht een zeer complex proces. Het bestaat uit meerdere functionele systemen, waaronder het somatosensore, visuele, vestibulaire en cerebellaire systeem, dit in combinatie met het perifere neuromusculaire systeem. Naarmate we verouderen gaan deze systemen gestaag achteruit, wat uiteindelijk zal leiden tot een grotere kans op valincidenten en eventueel zelfs een bedreiging voor zelfstandig wonen zal vormen. Deze studie heeft bewezen dat meerdere aspecten in balans verbeteren waardoor wij verwachten dat het risico op vallen hopelijk vermindert. Verder lijkt het ook dat als men toch het evenwicht verliest men beter kan compenseren doordat het evenwicht na Taekwondotraining gecorrigeerd wordt vanuit de voorvoet, zoals jongeren over het algemeen doen. Hierdoor zou je dus als gevolg van Taekwondotraining in het geval van vallen, handhaving van het evenwicht, naar voren corrigeren waardoor de kans op een ernstige val afneemt.

Hierdoor hopen wij dus op een dubbel effect van Taekwondotraining, namelijk dat ouderen doordat ze minder ernstig en minder vaak vallen, ook minder vaak opgenomen dienen te worden in het ziekenhuis en zo dus de dure opnamekosten aanzienlijk verlagen en als tweede dat ze langer zelfstandig thuis zullen kunnen functioneren. Dit aangezien balans in veel algemeen dagelijkse activiteiten zeer belangrijk is, waarvan de meest voorkomende, bijvoorbeeld het aankleden betreft. Dit ook in relatie met ons deel van de studie waarbij gebleken is dat Taekwondotraining er voor zorgt dat de kracht en cardiorespiratoire fitheid op zijn minst stabiel blijft, zo niet verbetert.

Als we dan verder kijken naar een van de andere gevolgen van vergrijzing, namelijk de toename van het aantal personen met een $\mathrm{MCl}$ (mild cognitive impairment) dan wel in ernstigere zin een dementie, kunnen we ook hier concluderen dat Taekwondotraining hier een positieve en belangrijke invloed op heeft. Hierbij zeggende dat er op dit moment nog weinig oplossingen zijn voor dit probleem, de mogelijkheden die er zijn zoals bijvoorbeeld dagopvang dan wel opname in een verpleegtehuis zijn dan ook nog zeer kostbaar. Een andere oplossing is farmaceutisch en ook dit heeft een hoog kostenplaatje en staat nog maar in de kinderschoenen. Wij denken dus dat Taekwondotraining een manier is om leeftijd-gerelateerd cognitief verval te verminderen op een goedkope, veilige en leuke manier.

\section{Doelgroepen}

Voor wie buiten de wetenschap zijn de onderzoekresultaten interessant en waarom? 
Dit is een simpel en eigenlijk ook kort te beantwoorden vraag. Het is voor ons allemaal interessant en van belang, aangezien we (hopen) allemaal ouder (te) zullen worden en dit hoezeer we het ook proberen tegen te gaan beperkingen met zich meebrengt. Eigenlijk al na ons dertigste levensjaar gaan meerdere lichaamsfuncties langzaam maar uiteindelijk gestaag achteruit, variërend per persoon. Bijvoorbeeld bij vrouwen meer dan bij mannen, worden de botten steeds brozer en verhoogt de kans op breuken al bij een klein trauma. Zoals eerder ook al genoemd, vermindert ons evenwicht, bij meer dan $30 \%$ van de 65-plussers is het vestibulaire systeem significant verslechterd, met inherent hieraan ook een verhoogde kans op vallen.

Uiteraard zijn er ook andere sporten en andere manieren om dit tegen te gaan dan wel op te vangen. Helaas zijn echter de populairdere bio-energetische sporten, zoals bijvoorbeeld hardlopen en zwemmen duidelijk minder effectief op het gebied van balans als ook cognitie. En zoals bewezen in dit proefschrift is een leeftijd-geadapteerde Taekwondo training niet alleen erg leuk maar ook een stuk veiliger dan de meest gangbare sporten. De resultaten zijn derhalve van belang voor iedereen ouder dan 40 jaar, maar ook voor de vele Taekwondo-schoolhouders die moeten overwegen Taekwondolessen voor volwassen en oudere beginners te gaan verzorgen. Niet alleen zij, maar de gehele Taekwondo-organisatie zal Taekwondo voor de genoemde doelgroep in hun beleidsvoornemens moeten gaan opnemen, en dit Taekwondo onderdeel tot een regulier onderdeel van de sport moeten maken, inclusief het mogelijk maken van bijvoorbeeld stijlwedstrijden voor deze beginners. Ook overheidsinstellingen die zich met sport en ouderenzorg bezighouden dienen zich te realiseren hoeveel "winst" in gezondheidsopzicht geboekt zou kunnen worden bij een brede maatschappelijke invoering van Taekwondoparticipatie door volwassen en oudere beginners.

\section{Activiteiten/producten}

In welke concrete producten, diensten, processen, activiteiten of bedrijvigheid worden de onderzoekresultaten vertaald en vormgegeven?

Kort gezegd is het wat mij betreft nu de taak van Taekwondo-organisaties en overheidsinstellingen op gebied van gezondheid en vergrijzing om conclusies uit niet alleen mijn maar ook eerder verricht onderzoek conclusies te trekken en dit alles in de dagelijkse maatschappij te implementeren.

Langer gezegd; Zoals al eerder in dit hoofdstuk genoemd is vergrijzing een zeer belangrijk onderwerp en misschien wel dreiging in onze maatschappij. Hierom zou ik mij concreet kunnen voorstellen dat we met al bestaande infrastructuur gaan starten met Sekwondo-lessen, leeftijd-geadapteerde Taekwondolessen. In elk dorp is zo ongeveer wel een sporthal, deze staat vaak overdag leeg. Dit 
terwijl 65-plussers, wellicht nu 67-plussers, overdag geen grote verplichtingen hebben. Voor weinig kosten zou een wekelijks les Sekwondo vanuit de overheid/gemeente gestart kunnen worden. Het enige dat bekostigt dient te worden is wellicht de utiliteiten van de sportzaal, een Taekwondoleraar en enkele materialen, zoals bijvoorbeeld een stootkussen.

Zoals in dit proefschrift bewezen, is Sekwondo zeer veilig en bovendien erg leuk voor de deelnemers. Hiermee zorg je dat oudere mensen beweging hebben, ook contact met andere leeftijdgenoten, zo veel actiever blijven en zoals gezegd een betere balans houden, minder valgevaar, betere cognitie en met het oog op de lange termijn ook minder ziektekosten zullen opleveren.

\section{Innovatie}

In hoeverre zijn deze activiteiten/producten innovatief te noemen ten opzichte van het bestaande aanbod?

Uiteraard zijn er al sportactiviteiten voor oudere mensen, maar dit is per gemeente en regio onafhankelijk van elkaar opgezet. Meestal is hierbij ook een ander doel voor ogen, namelijk met name om ouderen bio-energetische sport te laten bedrijven. In andere woorden met het idee dat ze een goede conditie houden. Eén van de voorbeelden die ik noem is bijvoorbeeld zwemmen of aquagym. Vaak is dit allereerst niet direct voor ouderen ontworpen en is het dus niet aangepast voor oudere leeftijd. Hierdoor is de kans groter op blessures, verder ook op desinteresse en dat er dus vroegtijdig mee gestopt wordt. Ook zijn het vaak meer individuele sporten waardoor het groepsverband minder groot is en zo ook weer de kans groter is op afhaken.

Verder zoals eerder ook al genoemd is een bio-energetische sport zeker goed voor mensen van middelbare leeftijd, maar mist dit helaas ook de al eerder genoemde voordelen van een dynamische sport zoals Taekwondo. Namelijk het aspect van evenwicht houden, multi-taken verrichten waardoor de balans verbetert, men naar voren corrigeert en dus ook minder snel en indien wel, minder gevaarlijk valt . Ook verbetert een bio-energetische sport de cognitie in veel mindere mate aangezien je daarbij geen multi-taken hoeft uit te voeren dan wel complexe figuren moet onthouden en gebruiken.

Verder kan nog gedacht worden aan Tai-Chi als vervanging voor de Sekwondo, ook daarvan zijn vele artikelen en studies verschenen met een voordelig effect op meerdere fronten op middelbare leeftijd. Dit zou een interessante studie voor de toekomst zijn om de effecten van de soft martial art Tai-Chi te vergelijken met de hard martial art van Taekwondo. Mijn idee is doordat Taekwondo veel dynamischer en dus minder statisch is dan Tai-Chi met name op balans en evenwicht een groot 
voordeel heeft. Ook door de dynamiek en het motorisch complexe karakter van Taekwondo, heb je een snellere reactiesnelheid en respons nodig als ook meer multi-tasking, waardoor ik van mening ban dat de Sekwondo zeker een grote meerwaarde voor de maatschappij heeft ondanks andere sportgroepen voor ouderen.

\section{Planning en realisatie}

Op welke manier krijgt dit valorisatie traject vorm? Wat is de planning, zijn eventuele risico's, de marktkansen en wat zijn de kosten?

Op dit moment heeft onze onderzoeksgroep nog niet in detail naar dit valorisatie traject gekeken.

Wel zijn we al begonnen om langzaamaan het traject Sekwondo naam te geven. Zo heeft mijn promotor prof. Jan Lodder naar aanleiding van wat we allemaal ervaren hebben een boek geschreven, in zowel het Nederlands, als het Engels over onze nieuw opgezette manier van Taekwondo onderwijzen aan de middelbare mens. Hierom de naam Sekwondo, als in senioren oefenen Taekwondo uit. Daardoor heeft het in de wereld der Taekwondo al goede bekendheid gekregen.

Verder is een groot deel van onze deelnemers bij het onderzoek bij de lokale Taekwondoclub blijven trainen en door (met name in België) landelijke promotiedagen voor Sekwondo hebben ook andere 40-plussers zich inmiddels aangemeld en zijn gestart met Sekwondo.

Ook heb ik in het kader van de gepubliceerde artikelen en klein interview op de radio over ons project gegeven om meer bekendheid aan het fenomeen Sekwondo gegeven, dit is ook door lokale kranten overgenomen.

Er is inmiddels een Facebookpagina geopend (https://www.facebook.com/groups/GenXTKD/), en een website is in de maak; deze activiteiten worden thans door een internationaal team gedragen. Het doel is om duidelijk te maken wat momenteel al de omvang is van Taekwondo-participatie door volwassen en oudere beginners, uitbreiding van deze participatie te promoten, en officiële wedstrijden voor de doelgroep te gaan organiseren.

Na deze promotie zullen we bekijken wat de verdere opties van Sekwondo gaan zijn. 


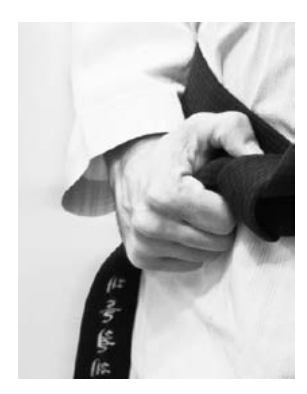

Curiculum Vitae 
Gaby Pons van Dijk was born on March $23^{\text {rd }}$ of 1982 in Cuijk, where she grew up. She attended secondary school at the Stedelijk Gymnasium in Nijmegen.

In 2000 she started at the Radboud University in Nijmegen to study medicine. She graduated at 2006. She then started working as a resident at the department of neurology of the Maxima Medical Centre in Veldhoven and moved to Veldhoven. In 2008 she started her training to become a neurologist in Maastricht University Medical Centre+, so she moved to the south of Holland.

A year later in 2009 she started with the Sekwondo study under supervision of prof. Dr. Jan Lodder and also started with Taekwondo training herself.

In 2013 she started with her two years of fellowship pediatric neurology in Maastricht, the Epilepsy Centre in Kempenhaeghe and the main part in University Hospitals of Leuven in Belgium. She completed her main specialty Neurology in 2014 and a year later her specialty Pediatric neurology.

In 2015 she started working as a (pediatric) neurologist in the Slingeland Hosiptal in Doetinchem. She and her husband are now living in Doetinchem.

Gaby Pons van Dijk is geboren op 23 maart 1982 in Cuijk, waar ze opgegroeid is. Ze ging naar de middelbare school, het Stedelijk Gymnasium, in Nijmegen.

In 2000 startte ze aan haar studie geneeskunde aan de Radboud Universiteit. Ze slaagde voor deze studie in 2006. Ze begon als arts-assistent op de afdeling neurologie van het Maxima Medisch Centrum te Veldhoven en verhuisde hier naar toe. In 2008 begon ze aan de opleiding tot neuroloog in het Maastricht Universitair Medisch Centrum+, waarop ze naar het zuiden van Nederland verhuisde.

Een jaar later begon ze aan de Sekwondo studie onder begeleiding van prof. Dr. Jan Lodder, en startte ook zelf met Taekwondotraining.

In 2013 startte zij met haar 2 jaar durende fellowship Kinderneurologie In Maastricht, epilepsie centrum te Kempenhaeghe en het grootste deel in Universitaire Ziekenhuizen Leuven in België. Ze behaalde haar specialisatie Neurologie in 2014 en een jaar later haar specialiteit Kinderneurologie.

In 2015 is ze met haar huidige baan als (kinder)neuroloog in het Slingeland Ziekenhuis te Doetinchem. Zij en haar man wonen nu in het centrum van Doetinchem. 


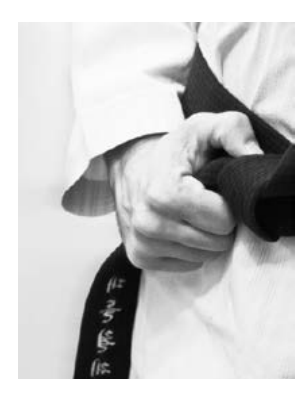

List of Publications 
Pons van Dijk G, Leffers P and Lodder J. Feasibility, safety and subjective experience of a one year WTF Taekwondo training course for middle aged volunteers: The Sekwondo study. Gaz Med Ital. 2013 June;172(6):433-41.

Pons van Dijk G, Lenssen AF, Leffers $\mathrm{P}$, Kingma $\mathrm{H}$ and Lodder J. Taekwondo training improves balance in volunteers over forty. Front. Ag. Neurosci. 2013. 5:10. doi: 10.3389/fnagi.2013.00010.

Pons van Dijk G, Huijts M, Lodder J. Cognition Improvement in Taekwondo Novices Over 40. Results from the SEKWONDO Study. Front Aging Neurosci. 2013 Nov 11;5:74. doi: 10.3389/fnagi.2013.00074.

Pons van Dijk G, Leffers P and Lodder J. The effectiveness of hard martial arts in people over forty: an attempted systematic review. Societies 2014, 4, 161-179.

Pons van Dijk G, van der Kooi EL, Behin A, Smeets JLRM, Timmermans J, van der Maarel SM, Padberg GW, Voermans NC and van Engelen BGM. High prevalence of incomplete right bundle branch block in Facioscapulohumeral Muscular Dystrophy patients without cardiac symptoms. Funct Neurol. 2014 Jan 11:1-7.

Pons van Dijk G, Lodder J. Health-scientific arguments from the SEKWONDO Study for a dedicated, world-wide promotion of Taekwondo training among adult, middle-aged and elderly people.Taekwondo Journal of Kukkiwon. 2015, 13, 179-1991, ISSN 2093-6753.

\section{Presentations}

Methylphenidate in children with narcolepsy with or without cataplexy. Poster presentation at the European Pediatric Neurology Society Congress 201 


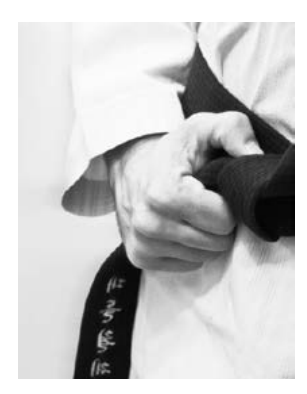

Dankwoord 
Na dagen uitgesteld te hebben, kom ik er toch niet onderuit om mijn dankwoord te schrijven. Hopelijk ga ik niemand vergeten en belangrijker nog, hoop ik dat ik mijn dank goed kan bewoorden. Want na alle pagina's die ik al geschreven heb, is mijn muze nu toch enigszins spoorloos.

Maar ik ga er vanuit dat de mensen die ik hier dank, mij kennen en dus weten dat ik het meen! Heel erg bedankt allemaal, ook de mensen die ik niet bij naam genoemd hebben en toch echt wel bijgedragen hebben.

Prof. dr. J. Lodder, beste Jan. Ik kan me nog goed herinneren dat je me vroeg of ik misschien promotie onderzoek wilde gaan doen. 'Ja, eigenlijk wel' dacht ik, tot jouw aanvulling van jouw idee kwam, de effecten van Taekwondotraining bestuderen. Toen heb ik toch echt wel even moeten nadenken wat ik hier nu van moest vinden! Aangezien ik er wel van hou om het anders dan de meeste mensen te doen, en daarbij omdat ik wist dat jij mij veel kon leren, ben ik er met twee benen tegelijk ingestapt. En ik moet zeggen het heeft eigenlijk geen moment teleurgesteld! Zo heb je me de mooie sport Taekwondo leren kennen, nu helaas even op een laag pitje, maar zo heb je me ook geleerd kritisch na te denken, verbanden te leggen en hypotheses te maken.

Ook heb je me geleerd in mezelf te geloven, want met dit bijzondere onderwerp als proefschrift hebben toch veel mensen gedacht dat dit nooit wat ging worden, maar we hebben ze toch mooi anders bewezen!! Jan, heel erg bedankt voor alle feedback, steun en in mij en ons project te geloven. Hoop dat we nog eens wat Grimbergen zullen drinken ;)

Prof. Dr. H. Kingma, beste Herman. Zonder jouw indrukwekkende kennis van evenwicht, was dit boekje er nooit gekomen. Heel erg bedankt voor het opzetten van dit deel van de studie en dat we jullie faciliteiten mochten gebruiken. Ook dank aan al je medewerkers die zo hard meegeholpen hebben. En natuurlijk ook dat ik gebruik mocht maken van je kennis en we zo toch een mooi artikel geschreven hebben.

Dr. A.F. Lenssen, beste Ton. Ook zonder jou was dit boekje er zeker niet gekomen, want jeetje wat hebben jij en de afdeling fysiotherapie veel voor mijn onderzoek betekend! Tevoren meegedacht welke tests we gingen gebruiken en daarna de voor- en de nametingen. Zo heb jij mij veel geleerd betreffende de methodiek en systematiek van wetenschappelijk onderzoek, dank. Ook Jona in het bijzonder en alle andere fysiotherapeuten, dank jullie voor je hulp.

Drs. P. Leffers, beste Pieter. Weken tot wel maanden hebben we aan het review gezeten, elke keer kwam jij weer met goede nieuwe ideeën. Je hebt me ontzettend veel geleerd over het opzetten van een systematisch review, en me daardoor soms tot wanhoop gedreven, maar dank voor het doorzetten!

Beste Marjolein Huijts, heel erg bedankt voor jouw tomeloze inzet, zonder jou was het cognitieve deel nooit van de grond gekomen. Welke onderzoeken wel zinvol zijn en waarom en uiteraard de uitvoering, want moeilijk was het wel om al die mensen voor- en na het jaar trainen te zien! Verder 
had ik mijn 5 maanden met alleen maar onderzoek in onze prachtige onderzoekskamer natuurlijk niet zonder jou en je mooie posters ;) overleefd!!

Eigenlijk had ik met jullie moeten beginnen, mijn 40-plussers, zonder jullie, kunnen we wel echt zeggen, was het nooit gelukt. Daar waren jullie dan week na week, meer dan 1 jaar lang in de catacomben van het MUMC om er weer een uur hard tegenaan te gaan. Sommige deelnemers bleven komen ondanks haarscheurtjes in hun voet, gigantische hematomen in de kuit, ga zo maar door, dank jullie allemaal! Jullie hebben niet alleen gezorgd dat ik iets te onderzoeken had, maar er ook nog eens een heel leuk jaar van gemaakt. Oprecht, dank!

De leden van de beoordelingscommissie, Prof dr. R. Van Oostenbrugge, Prof. Dr. R. Ponds, Prof. Dr. T.hortobagyi en Prof. Dr. J. Verbunt wil ik bedanken voor de tijd en moeite die jullie hebben genomen om mijn proefschrift te beoordelen.

Verder wil ik Robert van Oostenbrugge, Hans Vles en Lieven Lagae danken voor een goede opleiding in de neurologie en kinderneurologie, vooral dank dat ik mijzelf mocht blijven en natuurlijk voor jullie kennis!

In het verlengde hiervan wil ik ook alle assistenten neurologie (en fellows kinderneurologie in Leuven) bedanken voor de gezellige tijd en steun aan elkaar. En natuurlijk dank aan alle medewerkers van de afdeling neurologie. In het bijzonder Kitty Verwoerdt, die door de jaren heen heel wat (vakanties;)) mogelijk heeft gemaakt, dank!

Lieve Annelien, misschien heb je me niet ontzettend veel bij mijn onderzoek zelf geholpen maar wel met de afleiding daar omheen en eigenlijk met een heleboel. Het maakt niet uit waar het over gaat, ik kan het er met jou altijd over hebben. Ik weet echt niet wat ik zonder jou in Maastricht had gedaan, waarschijnlijk zou ik het drie landen punt niet ontdekt hebben....! Ik hoop, en ga er vanuit, dat we ondanks de plotse afstand, nog lang vriendinnen zijn en nog vele keren zullen lunchen en onnodige kleren kopen!

Lieve grote zussen, al hebben jullie me ook niet per se tijdens mijn onderzoek geholpen, wel in de weg er naar toe! Yolanda die geen zin meer had haar kleinste zusje voor te lezen, dus me als juffrouw in de dop veel te vroeg heeft leren lezen en ik kan zeggen, zeer cliché, een gift that keeps giving! Esmeralda, jij bent voor mij het voorbeeld geweest dat je ook leuke en toffe dingen moet doen, ook als dat niet verstandig is! (Wel blij dat je dat zelf iets minder doet ;))

Annemieke en Gé, jullie bedankt voor altijd te vragen hoe het met mijn onderzoek ging en dat jullie al bijna een jaar lang, elke keer dat jullie even naar Drankrijk gingen, al aan het controleren waren dat ik dan niet zou promoveren. En natuurlijk bedankt voor het opvoeden van zo een geweldige jongen, want zonder hem zou ik het nooit gekund hebben!

Papa en mama, voor jullie heb ik eigenlijk geen woorden, denk ook eigenlijk dat jullie wel weten dat ik jullie dankbaar ben, voor alles!! Papa y mama muchísimas gracias, dank je dat jullie me altijd vertrouwd hebben en me nergens in gepusht hebben, met name dat jullie me groep 4 niet hebben 
laten over slaan, zodat ik toch ook in sociaal vlak heb kunnen ontwikkelen, denk dat ik anders nog steeds met een neus in mijn boek over straat liep...

Lieve lieve Joris, jaja, daar is ie dan mijn dankwoord voor jou, denk dat ik nog wel een paar pagina's nodig heb. Want jeetje, jij bent naar het eind van de wereld, eh Nederland, voor me gegaan, naar Maastricht, ongelooflijk. Het maakte je niet uit wat nodig was om mijn droom, neuroloog te worden, te volbrengen. Ongelooflijk, echt waar, ik hoop dat je weet dat ik daar echt heel blij mee ben en dat je echt de allerliefste en beste bent. Ik meen het, hoe had ik het zonder jou ooit af kunnen maken, ik weet niet of ik al die rigoureuze stappen in mijn eentje had durven maken, maar met jou naast mijn zijde durfde ik er met ogen dicht in te springen. Om zo ook maar de analogie van onze duik- en reisavonturen te gaan. Met jou naast mij, ben ik onoverwinnelijk en durf ik zelfs de diepste cenote in!! Hoop dat je nog lang mijn hand wil vasthouden en me af en toe in het diepe wilt duwen. Op naar de volgende uitdaging, de achterhoek en wie weet wat nog meer allemaal...

Verder zal ik nu stoppen, voor het echt te cliché wordt... want zoals jij zou zeggen, twee woorden, negen letters. Dikke kus, $x$ 